\title{
Environmental Audit of Municipal Solid Waste Management
}

\author{
T. V. Ramachandra Shruthi Bachamanda \\ Energy and Wetlands Research Group \\ Centre for Ecological Sciences \\ Indian Institute of Science \\ Bangalore
}

\begin{abstract}
The management of municipal solid waste has become an acute problem due to enhanced economic activities and rapid urbanisation. Increased attention has been given by the government in recent years to handle this problem in a safe and hygienic manner. In this regard, Municipal Solid Waste Management (MSWM) environmental audit has been carried out for Bangalore city through the collection of secondary data from the government agencies, and interviewing stakeholders and field surveys. Field survey was carried out in seven wards (representative samples of the city) to understand the practice and the lacuna. The audit was carried out functional element wise in selected wards to understand the efficacy and shortfalls, if any, of MSWM. 49\% of the bins are covered while evaluating storage options. $17.5 \%$ of the commercial areas have community bins and $94 \%$ of the residential areas have adopted a doorto-door method for the collection of waste. Segregation of wastes in these methods of collection is $3 \%$. There are no transfer stations presently and large-scale trucks have been used in a few wards to carry out the functions of a transfer station. Among the trucks used for the disposal of wastes from wards to disposal sites, $41.43 \%$ are polythene covered. Recycling carried out mainly by the informal sector (rag pickers) has high level of efficiency and the recyclables are being retrieved by this sector at all stages starting from collection to disposal of wastes at dump sites. As the major composition of waste is organic, waste treatment options like composting is successful in Bangalore and currently 3.14\% waste reduction is achieved through composting. Ultimately, about $60 \%$ of the waste is disposed in dump yards and a balance of $21.14 \%$ is disposed in open quarry sites.
\end{abstract}

Keywords: solid waste; environmental auditing; functional elements; composting; landfill sites; municipal solid waste management 


\section{TABLE OF CONTENTS}

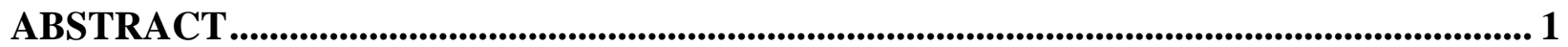

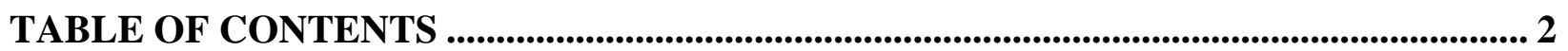

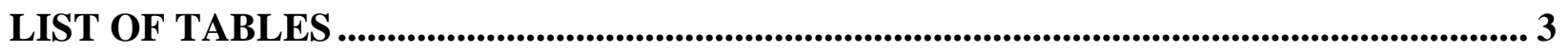

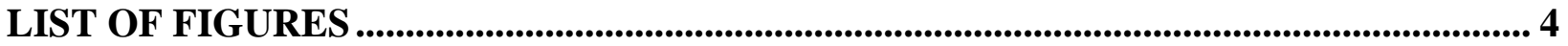

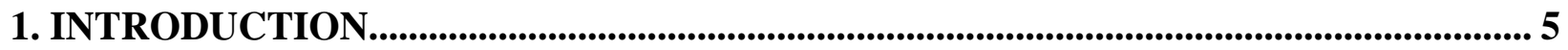

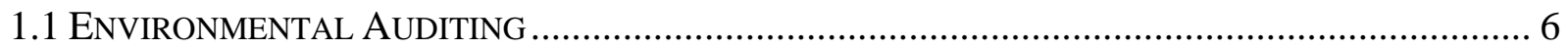

1.1.1Principle Elements of an Environmental Audit .............................................................. 8

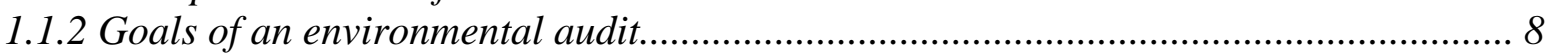

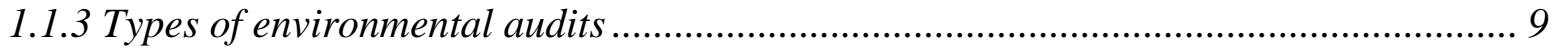

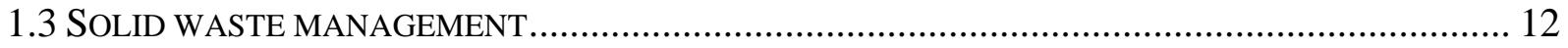

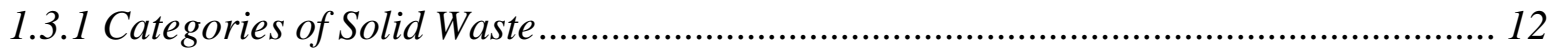

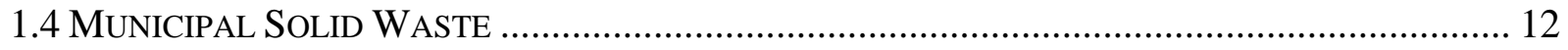

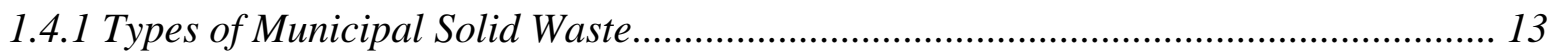

1.4.2 Municipal Solid Waste Management ........................................................................ 13

1.5 ENVIRONMENTAL AND HEALTH RISK SCENARIOS............................................................ 14

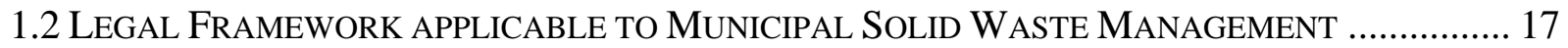

1.6 FunCtional ELEMENTS OF MUNICIPAL Solid WASTE MANAGEMENT .................................. 18

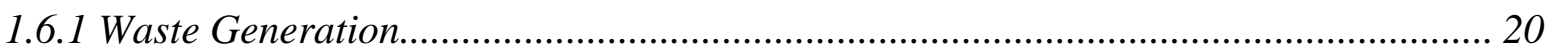

1.6.2 Waste Handling, Sorting, Storage, and Processing at the source .............................. 21

1.6.3 Collection ................................................................................................................... 22

1.6.4 Sorting, processing and transformation of Solid Waste ................................................ 23

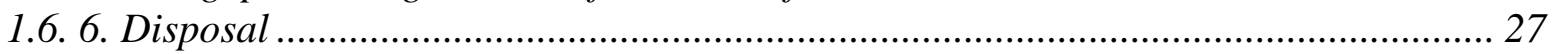

1.7 Municipal SOLID WASTE MANAGEMENT SYSTEMS IN INDIA............................................... 28

2. STUDY GOALS............................................................................................................................ 31

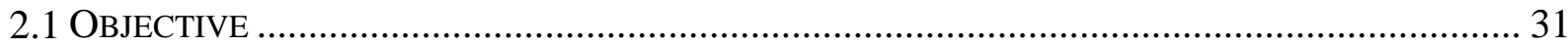

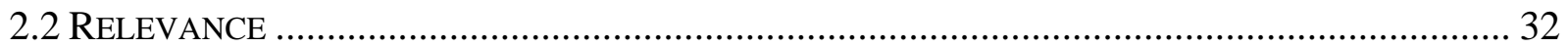

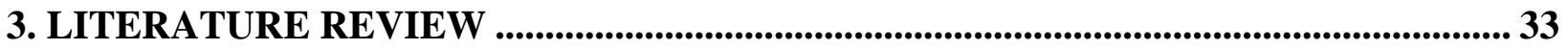

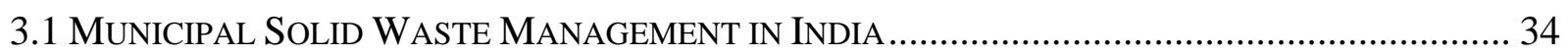

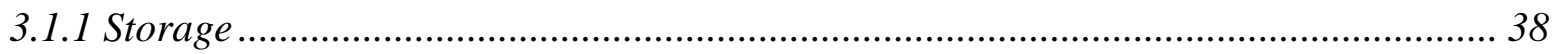

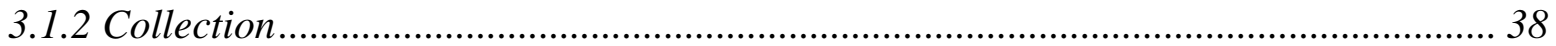

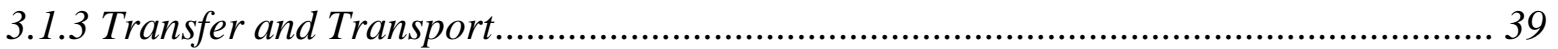

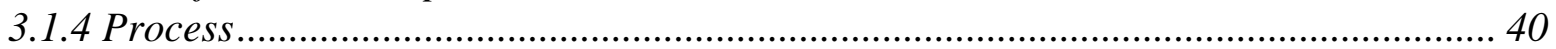

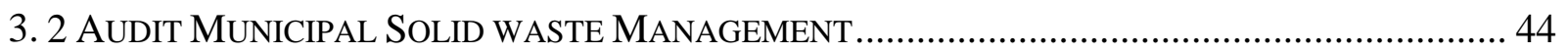

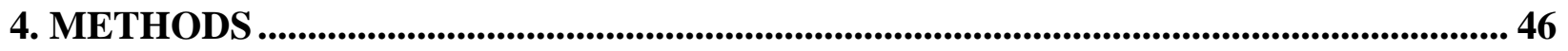

5. A CASE STUDY- ENVIRONMENTAL AUDIT OF MSWM IN BANGALORE CITY 49

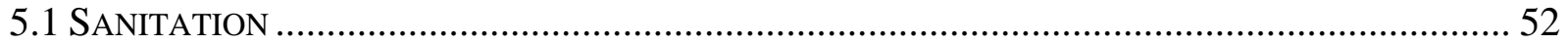

5.2 WARd Wise Population of The Bangalore City Corporation, 2001 ......................... 53 
5.3 CURRENT MSWM PRACTICE IN BANGALORE CITY ……...................................................... 54

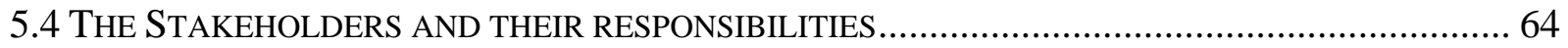

6. RESULTS AND DISCUSSION ............................................................................................68

7. FUTURE RESEARCH DIRECTION........................................................................ 112

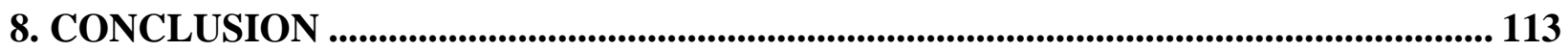

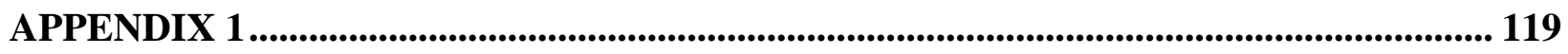

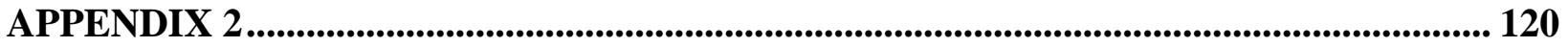

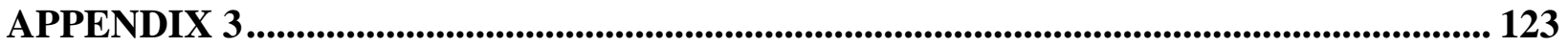

\section{LIST OF TABLES}

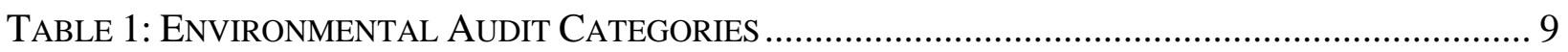

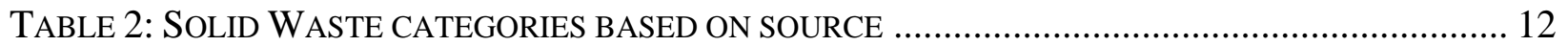

TABLE 3: THE SOURCES OF MUNICIPAL SOLID WASTE ……..................................................... 13

TABLE 4: RELATIVE COMPOSITION OF HOUSEHOLD WASTE IN LOW, MEDIUM AND HIGH-INCOME

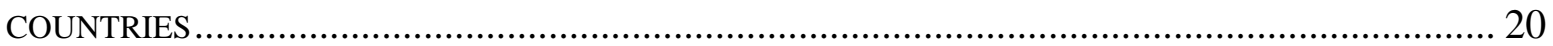

TABLE 5: DESIRABLE RANGE OF IMPORTANT WASTE PARAMETERS FOR TECHNICAL VIABILITY OF

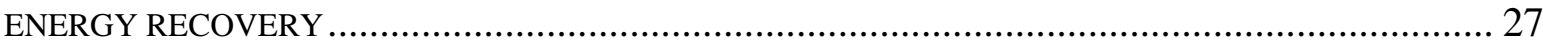

TABLE 6: DIFFERENCE BETWEEN INDUSTRIALIZED AND DEVELOPING NATIONS AFFECTING THE

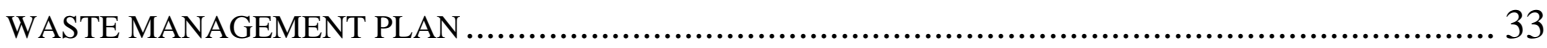

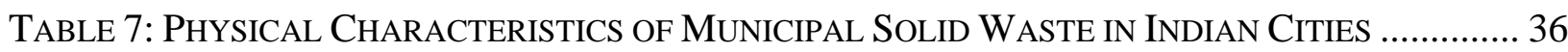

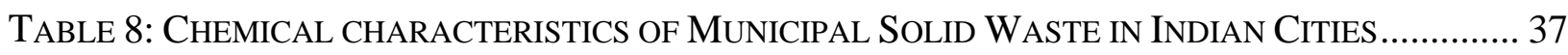

TABle 9: Density of Municipal Solid WASTES IN SOME CitIES .................................................. 37

TABLE 10: RESOURCE MATERIAL ............................................................................................ 46

TABLE 11: PhySiCAL CHARACTERISTICS OF BANGALORE MUNICIPAL SOlID WASTE...................... 55

TABLE 12: Health WARDS Covered under House-to-House Collection IN 2003................. 56

TABLE 13: VEGETABLE / FRUIT MARKETS ................................................................................ 56

TABLE 14: THE TYPE AND NUMBER OF VEHICLES IN BANGALORE METROPOLITAN AREA ............... 57

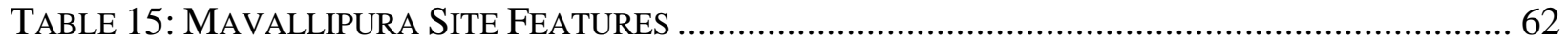

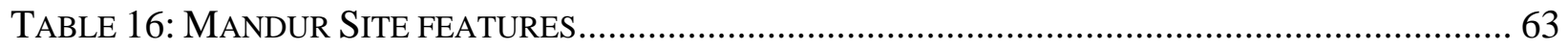

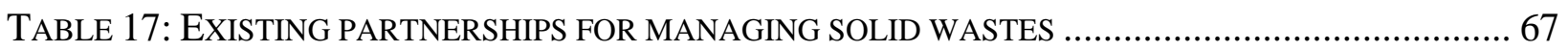

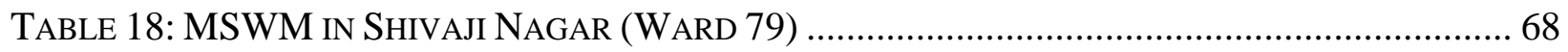

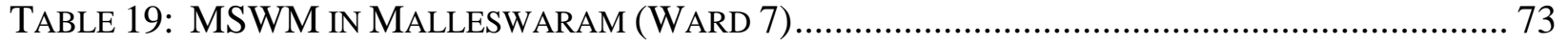

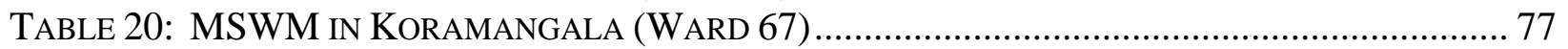

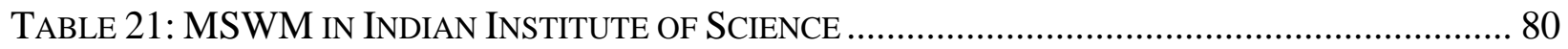

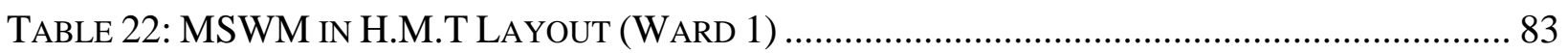

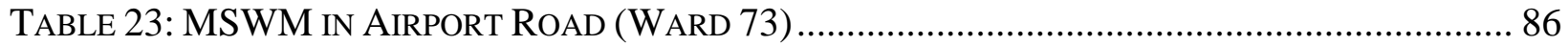

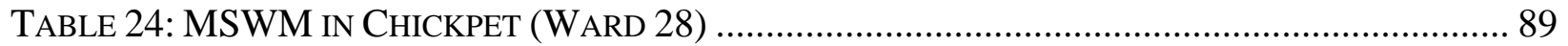

TABLE 25: TECHNIQUE ADOPTED AND RESOURCE MANAGEMENT IN ALL WARDS............................ 95

TABLE 26: AdVANTAGES AND DisAdVANTAGES OF RESOURCE USED ............................................... 96 


\section{LIST OF FIGURES}

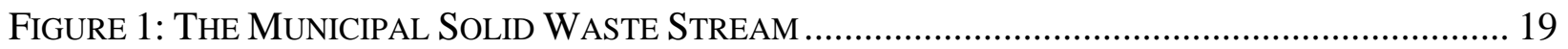

Figure 2: MUNICIPAL SOLID WASTE MANAGEMENT SYSTEM IN INDIA .................................... 30

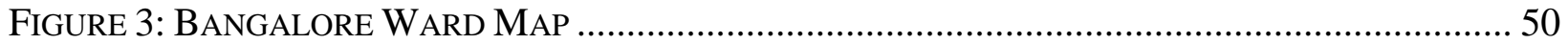

FIGURE 4: BANGALORE MAP REPRESENTING POPULATION DENSITY PER WARD ............................. 51

FIGURE 5: CURRENT MSWM PRACTICE IN BANGALORE CITY .............................................. 54 


\section{Environmental Audit of Municipal Solid Waste Management}

\section{INTRODUCTION}

Waste is a continually growing problem at global and regional as well as at local levels. Solid wastes arise from human and animal activities that are normally discarded as useless or unwanted. In other words, solid wastes may be defined as the organic and inorganic waste materials produced by various activities of the society and which have lost their value to the first user. As the result of rapid increase in production and consumption, urban society rejects and generates solid material regularly which leads to considerable increase in the volume of waste generated from several sources such as, domestic wastes, commercial wastes, institutional wastes and industrial wastes of most diverse categories. Management of solid waste may be defined as that discipline associated with the control of generation, storage, collection, transfer and transport, processing, and disposal of solid wastes in a manner that is in accord with the best principles of public health, economics, engineering, conservation, aesthetics, and other environmental considerations. In its scope, solid waste management includes all administrative, financial, legal, planning, and engineering functions involved in the whole spectrum of solutions to problems of solid wastes thrust upon the community by its inhabitants (Tchobanaglous, G. et al, 1997). Solid wastes have the potential to pollute all the vital components of living environment (i.e., air, land and water) at local and at global levels. The problem is compounded by trends in consumption and production patterns and by continuing urbanization of the world. The problem is more acute in developing nations than in developed nations as the economic growth as well as urbanization is more rapid.

This issue has now received the attention by international and national policy making bodies and citizens. In the international level the awareness regarding waste began in 1992 with the Rio Conference, here waste was made one of the priorities of Agenda $21^{*}$. Here specific attention

\footnotetext{
"Agenda 21 is a comprehensive plan of action to be taken globally, nationally and locally and was adopted by more than 178 Governments at the UN Conference in Rio de Janeiro.
} 
was given to the environmentally sound management of solid wastes. The Johannesburg World Summit on Sustainable development in 2002 focused on initiatives to accelerate the shift to sustainable consumption and production, and the reduction of resource degradation, pollution, and waste. The priority was given to waste minimization, recycle, and reuse followed by the safe disposal of waste to minimize pollution.

The government of India started encouraging proper management of solid waste as early as 1960's by giving loans for setting composting plants for MSW. The government of India over the years has taken many initiatives and implemented new technologies and methods. With the rapid urbanization, the problem of the MSWM problem has compounded and India is awakening to the magnitude of the problem. Due to increased public awareness of MSWM, a public litigation was filed and resulted in the Municipal Solid Waste (Management and Handling) Rules, 2000. Government for the first time now has included private organizations in providing this public service. New methods of storage, collection, transportation, processing and disposal are being implemented. It is necessary to evaluate the current process at this stage to understand if the methods being implemented are suitable for the Indian scenario and to identify the lacuna in the methods being adopted. This can be achieved by carrying out an audit. An audit not only brings out the shortcomings in a system, but also raises awareness on the problems addressed. Audit of a waste management system is a way to reduce problems caused by waste by revealing the shortcomings of the management system, the responsible actors and identifying the actors and the areas that need improvement. This endevour aims at evaluating the Indian MSWM scenario through literatures review and a case study of Bangalore city.

\subsection{Environmental Auditing}

Environmental Auditing can be defined as a management tool comprising a systematic, well documented, periodic and objective evaluation of how well the management systems are performing with the aim of helping to safeguard the environment by:

a) Facilitating management control of environmental practices, and

b) Assessing compliance with national legislation, which would include regulatory requirements. 
Environmental Auditing first began with the principle of 'polluters pay' to prevent liabilities towards the government. The other important reason could be due to the increasing awareness of the public about environmental protection, the companies voluntarily carried out audits of its operations and processes to prove that their products are environmentally friendly.

Environmental audit was introduced in India for the minimization of generation of wastes and pollution. In this regard a gazette notification was issued by the Ministry of Environment and Forests on March 13, 1992 and later amended vide notification GSR 386 (E) on dated April 22 1993. This notification applies to every person carrying on an industry, operation or process requiring consent to operate under Section 25 of the water (Prevention and Control of Pollution) Act, 1974 or under Section 21 of the Air (Prevention and Control of Pollution) Act, 1981 (14 of 1981), or both, or authorization under the Environmental Protection Act, 1986 (29 of 1986) (Srivastava, A. K. 2003). The notification requires that an Environmental Statement for the financial year ending the $31^{\text {st }}$ March be submitted to the concerned State Pollution Control Board, on or before the $30^{\text {th }}$ September of the same year.

The ISO standard is an example of commercial environmental auditing initiative. ISO stands for the International Standards Organization, located in Geneva, Switzerland. ISO is a nongovernmental organization established in 1947. The organization mainly functions to develop voluntary technical standards that aim at making the development, manufacture and supply of goods and services more efficient, safe and clean

Other types of environmental investigations are frequently conducted with audit like methodologies- such as open inventories and operated oriented investigations, into prevention of waste and pollution. These studies should be defined separately to avoid mistakes.

Thus it is useful to distinguish between three types of audit like processes:

1. Environmental Reviews: These involve an unprejudiced investigation of a company's environmental interactions, impacts and performances, with the aim of establishing an environmental protection system, including organizational and technical measures in addition to assessment and auditing procedures. 
2. Environmental Audit: This requires a systematic and objective investigation of a company's environmental activities, management and equipment against a predetermined set of criteria (legislation, standards, company policy and objectives, etc.).

3. Pollution Prevention Assessments: These involve a systematic, periodic and internal investigation of a company's process and operations designed to identify and provide information about opportunities to prevent pollution and waste.

Source (Benjamin Ntim, 1995)

There are various types of auditing, but all types of auditing include three groups of people and are divided into three stages. The three groups of people are auditor, auditee and the third party. The auditor is person or group doing the audit, the auditee is the people or things on whom the audit is done and the third party is people who want to know the results of the audit. The three stages are to assess, test and attest. Assess is to evaluate the current process, test is to compare how they ought to be and attest is to certify or testify the results if necessary (Ralf Buckley, 1991).

\subsubsection{Principle Elements of an Environmental Audit}

- Internal Audit is an audit carried out by the organization to check its own process and progress.

- External audit is an audit carried out by one organization of another organization to check its progress.

- Mandatory Audit is an audit carried out by an authority to check the compliance of the process with their requirements. For e.g. insurance checks, export, etc.

- Voluntary Audit is an audit carried out voluntarily by an organization or an individual of another organization to improve the process and compliance of the process with the laws.

Source (Ralf Buckley, 1991)

\subsubsection{Goals of an environmental audit}

Environmental audits can be carried out for a number of reasons. These could include any of the following:

- To verify compliance 
- To review implementation of policies

- To identify liabilities

- To review management systems

- To identify strengths and weaknesses

- To assess environmental performance

- To promote environmental awareness

A company or individual's motivation for carrying out an environmental audit will determine the type of audit it chooses to implement. Also, a company may want to carry out an environmental audit for one or all of the above reasons.

\subsubsection{Types of environmental audits}

An overview of different audit types and their use are given below. It should be noted that the divisions are not very sharp between the various types. Objectives and scope are often a combination of several audit types and are usually defined on a case-by-case basis. Many organizations have developed audit programs to fit in their particular need.

Based on Objectives environmental audit can be categorized as shown in Table 1

\section{Table 1: Environmental Audit Categories}

\begin{tabular}{|l|l|l|}
\hline Environmental Audit Types \\
\hline Liabilities Audit & Management Audit & Activities Audit \\
Compliance Audit & Corporate Audit & Site Audit \\
Operational Risk Audit & Systems Audit & Waste Audit \\
Acquisition Audit & Policy Audit & Product Audit \\
Health and Safety Audit & Issues Audit & Cross-boundary Audit \\
\hline
\end{tabular}


Liabilities Audit is often conducted as a prelude to gaining insurance cover and as a means of demonstrating the regulatory compliance.

- Compliance Audit is the most common form of environmental audit that is carried out, it is a verification process whereby the facility establishes the extent to which it is complying with the environmental legislation, regulations, emission limits, etc.

- Operational risk liability audit concentrate on the potential frequency and consequence of environmentally damaging activities in the various functions of the process. Compliance with regulation does not necessarily reduce liability due to operational risks.

- Acquisition audits assess the liabilities due to contaminated land and building remediation costs.

- Health and safety audits normally form part of Health, safety and Environment (HSE) audit and involve assessment of adequacy of personal protective equipments (safety, shoes, goggles, helmets, etc.), emergency preparedness and disaster management plans.

Management Audit pays considerable attention to management systems as they are a guide to how effectively and efficiently the operations runs

- A corporate audit is initiated by the main Board of a parent company and is concerned with the organisation structure, roles and responsibilities, policy implementation, awareness and communication. It is carried out as a reassurance to the main Board that their aims and objectives are being implemented throughout the corporate structure.

- Management systems audit are carried out to check the systems against the policy and standards such as British standard 7750 or ISO 14001.

- Policy audit is carried out to review and reassess the relevance of the policy in the light of developments (legal, technical, financial) within the organisation and outside.

- Issues audit is carried out to establish environmental management plan and targets.

Activities audit cover auditing of select technical and management issues.

- Environmental site audit examines all aspects of the facilities performance with respect to the environment. It combines most of the elements of other types of environmental assessment and when undertaken in depth involve considerable time and cost. 
- The waste audits are of two types. The first identifies and quantifies waste streams and is a precursor to both waste minimisation programmes. The second type assesses waste management practice and procedures.

- Product audits cover several aspects of their environmental impacts through design, manufacture, use and disposal. Such audits are pre-requisites for identifying environmentally friendly products for "Green labelling”.

- Cross boundary audits assess activities, which cut across departments or business units. Transport and supply chain are such examples.

The audit is not an evaluation of alternatives that will optimize a course of action to solve operating, engineering, scientific, legal, technical, employee, or public relations problems. The objective of an environmental audit is to reveal whether the system is controlling in a way that will yield expected and understandable results. The audit will succeed if it reveals shortcomings as well as satisfactory conditions and identifies the necessary steps to cure the shortcomings and augment the satisfactory conditions. 


\subsection{Solid waste management}

Management of solid waste is associated with the control of generation, storage, collection, transfer and transport, processing, and disposal of solid wastes in a manner that is in accord with the best principles of public health, economics, engineering, conservation, aesthetics, and other environmental considerations. In its scope, it includes all administrative, financial, legal, planning and engineering functions involved in the whole spectrum of solutions to problems of solid wastes thrust upon the community by its inhabitants (Tchobanaglous, et al, 1997).

\subsubsection{Categories of Solid Waste}

Solid waste can be categorized based on source as shown in table 2 .

Table 2: Solid Waste categories based on source

\begin{tabular}{|c|c|c|}
\hline Source & $\begin{array}{l}\text { Typical facilities, activities, or } \\
\text { locations where wastes are generated }\end{array}$ & Types of Solid waste \\
\hline Agricultural & $\begin{array}{l}\text { Field and row crops, orchards, } \\
\text { vineyards, diaries, feedlots, farms, etc }\end{array}$ & $\begin{array}{l}\text { Spoiled food wastes, agricultural } \\
\text { wastes, rubbish, and hazardous } \\
\text { wastes }\end{array}$ \\
\hline Industrial & $\begin{array}{l}\text { Construction, fabrication, light and } \\
\text { heavy manufacturing, refineries, } \\
\text { chemical plants, power plants, } \\
\text { demolition, etc. }\end{array}$ & $\begin{array}{l}\text { Industrial process wastes, scrap } \\
\text { materials, etc.; nonindustrial waste } \\
\text { including food waste, rubbish, ashes, } \\
\text { demolition and construction wastes, } \\
\text { special wastes, and hazardous waste. }\end{array}$ \\
\hline $\begin{array}{l}\text { Commercial and } \\
\text { Institutional }\end{array}$ & $\begin{array}{l}\text { Stores, restaurants, markets, office } \\
\text { buildings, hotels, auto repair shops, }\end{array}$ & $\begin{array}{l}\text { Paper, cardboard, plastics, wood, } \\
\text { food wastes, glass, metal wastes, } \\
\text { ashes, special wastes, etc. }\end{array}$ \\
\hline $\begin{array}{l}\text { Municipal solid } \\
\text { waste }\end{array}$ & $\begin{array}{l}\text { Includes residential, commercial and } \\
\text { institutions }\end{array}$ & $\begin{array}{l}\text { Special waste, rubbish, general } \\
\text { waste, paper, plastics, metals, food } \\
\text { waste, etc. }\end{array}$ \\
\hline
\end{tabular}

Source: (Hester, R. E and Harrison, R. M., 2002)

\subsection{Municipal Solid Waste}

The term municipal solid waste (MSW) is normally assumed to include all of the waste generated in a community, with the exception of waste generated by municipal services, treatment plants, and industrial and agricultural processes (Tchnobanoglous, G and Kreith, F., 2002). In the urban context the term municipal solid wastes is of special importance. The term refers to all wastes collected and controlled by the municipality and comprises of most diverse 
categories of wastes. It comprises of wastes from several different sources such as, domestic wastes, commercial wastes, institutional wastes and building materials wastes.

\subsubsection{Types of Municipal Solid Waste}

\section{Table 3: The sources of municipal solid waste}

\begin{tabular}{ll}
\hline Sources & Examples \\
\hline Residential & Single family homes, duplexes, town houses, apartments \\
Commercial & Office buildings, shopping malls, warehouses, hotels, airports, restaurants \\
Institutional & Schools, medical facilities, prisons \\
Industrial & Packaging of components, office wastes, lunchroom and restroom wastes (but \\
& not industrial process wastes)
\end{tabular}

Source (Tchobanoglous, G and Kreith, F., 2002)

\subsubsection{Municipal Solid Waste Management}

Municipal Solid waste management involves the application of principle of Integrated Solid Waste Management (ISWM) to municipal waste. ISWM is the application of suitable techniques, technologies and management programs covering all types of solid wastes from all sources to achieve the twin objectives of (a) waste reduction and (b) effective management of waste still produced after waste reduction.

In the Municipal Solid Waste Management the major issues to be considered are:

- Increasing waste quantities

- Wastes not reported in the national MSW totals

- Lack of clear definition for solid waste management terms and functions

- Lack of quality data

- Need for clear roles in state and local government

- Need for even and predictable enforcement regulations and standards 


\subsection{Environmental and Health risk scenarios}

Potential hazards of solid wastes are numerous to the living community when it is improperly managed. Solid wastes have the potential to pollute all the vital components of living environment (i.e., air, land and water). Some of the hazards caused by solid wastes are listed below;

1. Uncollected wastes often end up in drains, causing blockages that result in flooding and unsanitary conditions.

2. Open and overflowing bins attract stray dogs, which has been a major cause of the spread of rabies.

3. Open waste bins also attract stray and domestic cattle. Cattle in the city causes nuisance by blocking the traffic on the roads. Cattle that graze on the waste from bins end up eating the plastic along with the vegetable matter, which proves to be fatal for them. The milk obtained from the cattle that feed on waste can be contaminated and can prove to be unsafe for human health.

4. Flies breed in some constituents of solid wastes, and flies are very effective vectors that spread disease.

5. Mosquitoes breed in blocked drains and in rainwater that is retained in discarded cans, tire and other objects. Mosquitoes spread disease, including malaria and dengue.

6. Rats find shelter and food in waste dumps. Rats consume and spoil food, spread disease, damage electrical cables and other materials and inflict unpleasant bites.

7. The open burning of waste causes air pollution; the products of combustion include dioxins that are particularly hazardous.

8. Aerosols and dusts can spread fungi and pathogens from uncollected and decomposing wastes.

9. Uncollected waste degrades the urban environment, discouraging efforts to keep streets and open spaces in a clean and hygienic condition. Plastic bags are in particular an aesthetic nuisance. 
10. Waste collection workers face particular occupational hazards, including strains from lifting, injuries from sharp objects and contact with pathogens when manually handling the waste.

11. Dangerous items (such as broken glass, razor blades, hypodermic needles and other healthcare wastes, aerosol cans and potentially explosive containers and chemicals from industries) may pose risks of injury or poisoning, particularly to children and people who sort through the waste.

12. Heavy refuse collection trucks can cause significant damage to the surfaces of roads that were not designed for such weights.

13. Waste items that are reused without being cleaned effectively or sterilized can transmit infection to later users. (Examples are bottles and medical supplies.)

14. Polluted water (leachate) flowing from waste dumps and disposal sites can cause serious pollution of water supplies, ponds and lakes. Chemical wastes (especially persistent organics) may be fatal or have serious effects if ingested, inhaled or touched and can cause widespread pollution of water supplies.

15. Waste that is treated or disposed of in unsatisfactory ways can cause a severe aesthetic nuisance in terms of smell and appearance.

16. Liquids and fumes, escaping from deposits of wastes (perhaps formed as a result of chemical reactions between components in the wastes), can have fatal or other serious effects.

17. Methane (one of the main components of landfill gas) is much more effective than carbon dioxide as a greenhouse gas, leading to climate change.

18. Fires on disposal sites can cause major air pollution, causing illness and reducing visibility, making disposal sites dangerously unstable, causing explosions of cans, and possibly spreading to adjacent property.

19. Former disposal sites provide very poor foundation support for large buildings, so buildings constructed on former sites are prone to collapse.

20. Rag pickers working on landfill are prone to many diseases like respiratory infections such as lung impairment. In a study carried out by Chittaranjan national Cancer Institute, Kolkata compared the health of Delhi's rag pickers with that of the control subjects from east Delhi slums. Nearly 75.5 rag pickers from the sample group of 98 had higher 
frequency of upper respiratory symptoms (sinusitis, running or stuffy nose, sore throat, common cold, fever) and 81.6 per cent showed lower respiratory symptoms (dry cough, cough with phlegm, wheezing, and chest discomfort) and breathing problem.

Numerous technologies / options are available in SWM, among developed countries. Replicating the same in low-income countries is inappropriate / incompatible. The success of waste disposal practices depends largely on overcoming the following constraints,

- MUNICIPAL CAPACITY: The scale of task is enormous and regulatory authorities are able to collect only $60-70 \%$ of total waste generated, so treatment and disposal inevitably receives less attention. Attempts are being made in a few instances to overcome this lack of capacity by privatizing this operation.

- POLITICAL COMMITMENTS: Solid waste management is much more than a technical issues; it has implications for local taxation, employment, and regulation of public and managing authorities. Any change needs political support to be effective. However, it is rarely a priority for political concerns unless there is strong and active public interest. This is viewed as a cost to the "public" without apparent returns.

- FINANCE, COST RECOVERY AND RESOURCE CONSTRAINTS: Deployment of a proper management system represents a major investment and it may be difficult to give it priority over other resource demands. Most of the waste management authorities are severely constrained by the lack of resource to finance their services. Since the collection and transport itself usually dominate SWM costs in developing countries, safe disposal invariably receives less attention where as in all other developed countries concentrate on all aspects of management.

- TECHNICAL GUIDELINES: Standards of planning and implementation in highincome countries may not be appropriate in low-income countries due to difference in climate, resource, institutions, attitude priorities, etc. However, relatively little appropriate guidance is available for low-income countries. Arising from this uncertainty, officials find themselves ill equipped to plan management strategies, which are both achievable and avoid unacceptable environmental hazards.

- INSTITUTIONAL RESPONSIBILITIES: Though managing wastes effectively is the responsibility of the municipality, there is no clearly stated vision of management (i.e. 
sufficient priority is not given to SWM). Existing vision is accompanied by a typical apathy to solid waste is an "out of sight is out of mind" attitude by the municipalities and public because of strict rule and regulations are not implemented just like as in prevention of emission of water and air pollutants. Waste management necessities the co-ordination of all authorities concerned and may involve departments that are accustomed to acting independently but the lack of accountability in all levels of management. Among the authorities, the roles and responsibilities of different departments need to be clearly defined and accepted by all concerned. Some smaller towns may not have staff with specific responsibility for providing a solid waste management service.

- INADEQUATE LEGAL PROVISIONS: In most countries, the laws and regulations on solid waste management are outmoded and fragmented and hence are inadequate to deal effectively with the modern complications of managing wastes in large cities. Most of the laws deal with the general tidiness of the city streets, waste collection and their disposal at places away from settlements. Even these inadequate laws are not fully enforced. This aggravates the situation further.

\subsection{Legal Framework applicable to Municipal Solid Waste Management}

Legislation concerning waste is usually differentiated according to the type of waste. International conventions often cover nuclear and hazardous waste, whereas non hazardous waste, often called solid waste is usually more regulated at the national level. From an environmental angle the following environmental rules, regulations and acts would be the most relevant for MSWM:

- Municipal Solid Waste (Management \& Handling) Rules 2000, notified by the ministry of Environment and Forests, Government of India vide notification No. S.O.908 (E) dated $25^{\text {th }}$ September 2000. The guidelines given in this law covers all the functional elements of municipal solid waste management.

- The Water (Prevention and Control of Pollution) Act, 1974. Two aspects have to be kept in mind of this law in regard to MSWM. Firstly, a consent from the state pollution control board for establishment of a sanitary landfill site and compost plant is essential 
and secondly, no water pollution should be caused by the leachate that is emitted by the sanitary landfill site or a compost plant.

- The Water (Prevention and Control of Pollution) Cess Act, 1977 and amendments thereon. The only aspect that should be considered in this law in regard to MSWM is provision for levying and collection of cess on water consumed for the sanitary landfilling, composting and anaerobic digesters.

- The Air (Prevention and Control of Pollution) Act, 1981 and amendments thereon. The aspects to be considered in this law with respect to MSWM is the need for obtaining consent from the State Pollution Control Board for establishment of the processing plants and disposal site and from an environmental aspect would be the pollution caused by incineration plants, compost plants and landfill sites.

- The Environmental (Protection) Act, 1986 and its subsequent notifications. The aspect in regard to MSWM would be the EIA notification, 1944, which states that for any project to be authorized an EIA report should be submitted first.

\subsection{Functional Elements of Municipal Solid Waste Management}

To implement proper waste management, various aspects have to be considered such as Waste generation (source reduction), Waste handling and sorting, storage and processing at the source (onsite storage), Collection, Sorting, processing and transformation, ransfer and transport, and Disposal (The Expert Committee, 2000). Figure 1, shows the interrelationship between the functional elements in solid waste management. 
Figure 1: The Municipal Solid Waste Stream

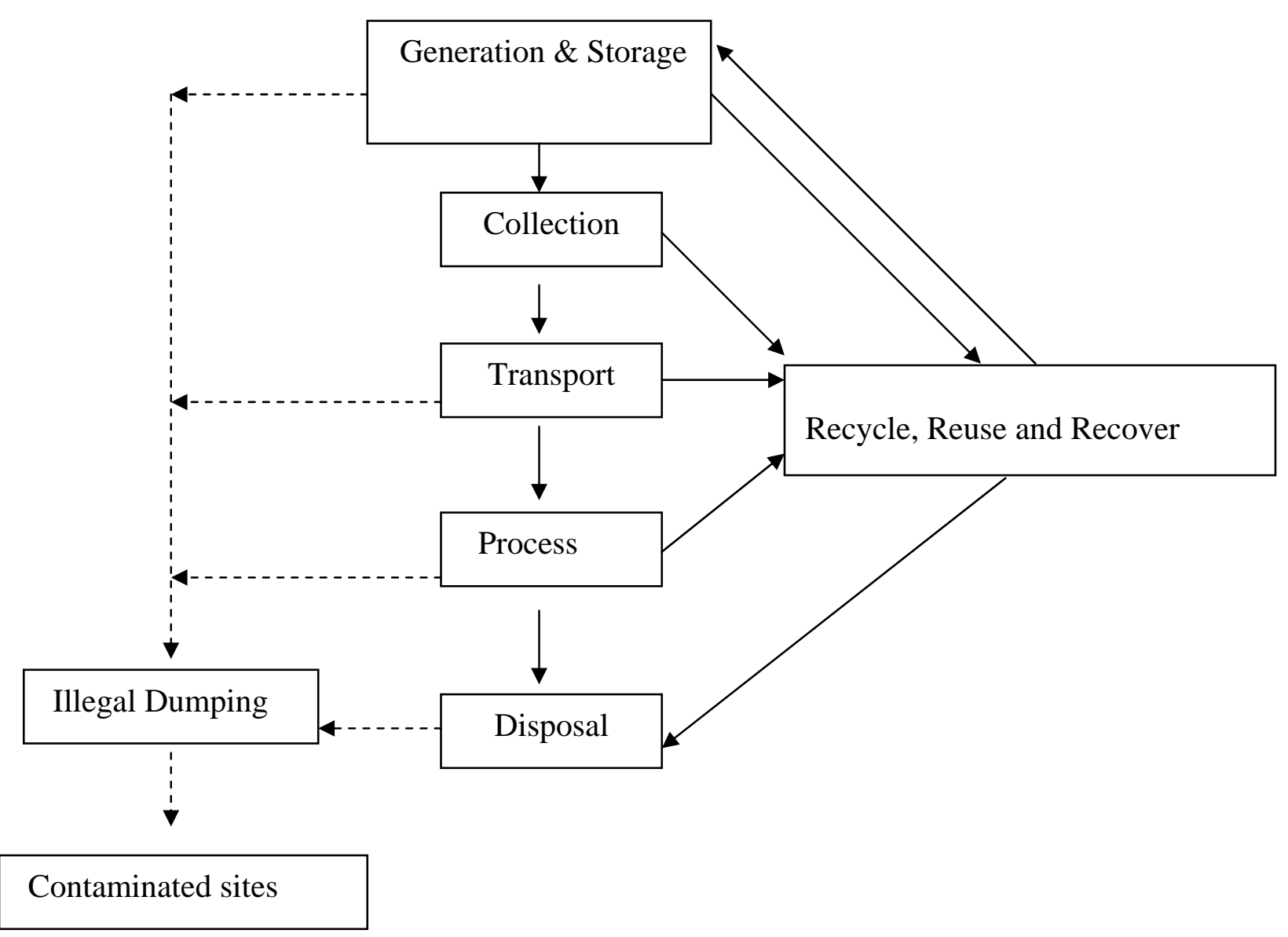




\subsubsection{Waste Generation}

Waste generation encompasses activities in which materials are identified as no longer being of value (in their present form) and are either thrown away or gathered together for disposal. Waste generation at present is not very controllable. However, reduction of waste at source is included in system evaluations as a method of limiting the quantity of waste generated.

The compositional terms that are used can vary a lot, from relatively simple descriptions in terms of organic to more complicated schemes, using many or all of the constituents, such as paper, plastic, glass, metal etc.

The composition of the waste is a description of the contents of the waste. In addition to providing important information about the way to handle the waste, the composition tells us about the people who generated the waste. The composition of waste varies widely from place to place, especially country to country.

Table 4: Relative composition of household waste in low, medium and high-income countries

\begin{tabular}{lllll}
\hline & Parameter & $\begin{array}{l}\text { Low-income } \\
\text { countries }\end{array}$ & $\begin{array}{l}\text { Medium- } \\
\text { income }\end{array}$ & $\begin{array}{l}\text { High-income } \\
\text { countries }\end{array}$ \\
\hline Contents & Organic (putrecible), \% & 40 to 85 & 20 to 65 & 20 to 30 \\
& Paper, \% & 1 to 10 & 15 to 30 & 15 to 40 \\
& Plastics, \% & 1 to 5 & 2 to 6 & 2 to 10 \\
& Metal, \% & 1 to 5 & 1 to 5 & 3 to 13 \\
& Glass, \% & 1 to 10 & 1 to 10 & 4 to 10 \\
& Rubber, leather, etc., \% & 1 to 5 & 1 to 5 & 2 to 10 \\
& Other, \% & 15 to 60 & 15 to 50 & 2 to 10 \\
& Moisture content, \% & 40 to 80 & 40 to 60 & 5 to 20 \\
Physical and & chemical Specific weight, $\mathrm{kg} / \mathrm{m}^{3}$ & 250 to 500 & 170 to 330 & 100 to 170 \\
properties & Calorific value, $\mathrm{kcal} / \mathrm{kg}$ & 800 to 1100 & 1000 to 1300 & 1500 to 2700 \\
\hline
\end{tabular}

Source: (INTOSAI working group on environmental auditing, 2002)

To illustrate the information that can be deduced from information on composition, we can start with table 4 that shows the average composition and amounts of waste for low, medium and high-income countries. 
The most striking difference that can be seen is the difference in organic content which is much higher in the low income countries than the high income countries and the paper and plastic content which is much higher in higher income countries than low income countries. This shows the difference in consumption pattern, cultural and educational differences

In higher income countries the usage of disposable material, magazines and packaged food is used in higher quantity that results in a waste having higher calorific value, lower specific density, and lower moisture content. In case of lower income countries the usage of fresh vegetables to packaged food is much higher and mostly materials that are reusable are used. This results in a waste composition that has high moisture content, high specific weight and low calorific value. This shows how waste statistics can be used to describe the life style of the people and also their income.

\subsubsection{Waste Handling, Sorting, Storage, and Processing at the source}

Waste handling and sorting involves activities associated with management of wastes until they are placed in storage containers for collection. Handling also encompasses the movement of loaded containers to the point of collection.

a) Sorting is an important component of waste management and best-done onsite. However, there are various stages of sorting. These can be identified as the following:

- At the source or house hold level

- At the community bin (municipal bin)

- At transfer station or centralised sorting facility

- At waste processing site (pre-sorting and post sorting)

- At the landfill site

b) Sorting Operations can be carried out in three ways:

- Manual sorting

- Semi-mechanised sorting

- Fully mechanised sorting

c) Onsite storage is of primary importance because of public health concerns. Open ground storage, make shift containers should always be avoided and only closed containers 
should be used. Processing at the source involves backyard composting. Storage of wastes can be done at three levels:

- At source

- At community level

- At transfer stations

\subsubsection{Collection}

This includes gathering the solid wastes and recyclable materials and transport of these materials to either the processing facility, transfer facility or the disposal site.

\section{Types of Collection}

i. Community bins- they are placed in convenient locations, where the community members carry the waste and throw it in. This method is comparatively cheaper to other methods. This is the most widely adopted method in western countries. For this method to be adopted it is important that the Bins are covered, they are aesthetic, they are attended to regularly, kept clean, easy to handle and separate bins are provided for recyclable, mixed, paper and biodegradable waste.

ii. Door-to-Door collection - The waste is placed at the doorstep at a set time when the waste collector arrives. In this method, it is the collector of the waste has the responsibility to collect the waste separately. This method is very convenient for the householder, however requires homeowner cooperation and scheduled service for homeowner cooperation.

iii. Block collection- the collection vehicles arrive at a particular place or a set day and time to collect waste from the households. Households bring their waste containers and empty directly into the vehicle. This method requires a higher homeowner cooperation and scheduled service for homeowner cooperation.

iv. Curbside collection - the homeowner is responsible for placing the containers to be emptied at the curb on the collection day and for returning the empty containers to their storage location until the next collection (Tchobanolous, $G$ et al 1993)

Street cleansing is another type of collection method mainly for collection of street litter. 


\subsubsection{Sorting, processing and transformation of Solid Waste}

This functional unit encompasses the recovery of the sorted materials, processing of solid waste and transformation of solid waste that occurs primarily in locations away from the source of waste generation.

Sorting of the mixed waste usually occurs at a material recovery facility, transfer stations, combustion facilities and disposal sites. Sorting includes separation of bulky items, separation of waste components by size using screens, manual separation of waste components, and separation of ferrous and non-ferrous metals.

Waste processing and transformation Solid waste processing reduces the amount of material requiring disposal and, in some cases produces a useful product. Examples of solid waste processing technologies include material recovery facilities, where recyclable materials are removed and/or sorted; composting facilities where organics in solid waste undergo controlled decomposition; and waste-to-energy facilities where waste becomes energy for electricity.

Landfilling continues to be required even if solid waste processing technologies are employed because all of these technologies produce some sort of residue or handle only a portion of the waste stream. For example, landfilling is still required for ash and bypass Waste (waste that can't be burned) from waste-to energy facilities. Thus, solid waste processing technologies do not replace landfilling; rather they are a part of an integrated system that reduces the amount of material that requires landfill disposal.

The different types of processing techniques are given below

Recycling and reuse- the process, by which materials otherwise destined for disposal are collected, reprocessed or remanufactured and are reused. The recycling and reuse (the use of a product more than once in its same form for the same or other purpose) sector of waste management in cities of Asian developing countries is potentially high. Its economic assessment is a difficult task since it is practised in an informal way. 
Composting is a biological process of decomposition carried out under controlled conditions of ventilation, temperature, moisture and organisms in the waste themselves that convert waste into humus-like material by acting on the organic portion of the solid waste (Sathishkumar, et al 2002). It produces a sludge, which is high in nutrients and can be used as a fertilizer. This is one element of an integrated solid waste management strategy that can be applied to mixed municipal solid waste (MSW) or to separately collected leaves, yard waste or food waste. There are various methods of composting, which are:

Bangalore method - This is an anaerobic method conventionally carried out in pits. The waste and the soil is alternatively laid out in layers and then is covered with a solid layer to prevent flies, odour and water seepage. This material is allowed to decompose for 4 to 6 months after which the stabilised material is taken out and used as compost.

Indore method- this method is similar to Bangalore method, however to ensure aerobic condition the material is turned at specific intervals. First turn is given manually after 4-7 days. $2^{\text {nd }}$ turn is given after 5-10 days and further turning is normally not required and the compost is ready in 2 to 4 weeks.

Windrow composting: is a common method of composting, it involves the stabilization of organic solid waste through aerobic degradation. The waste is piled in heaps with approximately a height of $3 \mathrm{~m}$, width of $1.5 \mathrm{~m}$ and varying lengths. The waste is left for 60 days for decomposition with weekly turnings to aerate the heaps. After which, it can be sieved and the compost is obtained.

Vermicomposting: is a comparatively new method in composting, it involves the stabilisation of organic solid waste through earthworm consumption that converts the material into earthworm castings. Vermicomposting is the result of combined activity of microorganisms and earthworms. 


\section{Energy recovery Processes}

The main Parameters, which determine the potential of recovery of energy from wastes (including MSW), are:

- Quantity of waste, and

- Physical and chemical characteristics (quality) of the waste

The important physical parameters requiring consideration include:

- Size of constituents

- Density

- Moisture content

Smaller size aids in faster decomposition of the waste. Waste of high density reflects a high proportion of biodegradable organic matter and moisture. Low-density wastes, on the other hand, indicate a high proportion of paper, plastic and other combustibles.

High moisture content causes biodegradable waste fraction to decompose more rapidly than in dry conditions. It also makes the waste rather unsuitable for thermo-chemical conversion (incineration, pyrolysis / gasification) for energy recovery, as heat must first be supplied to remove moisture.

Bio-chemical conversion: This process is based on the enzymatic decomposition of organic matter by microbial action to produce methane gas or alcohol. It is preferred for wastes having high percentage of organic biodegradable (putriscible) matter and high level of moisture/water content, which aids microbial activity.

Biogasification- also called biomethanisation is the process of decomposing biomass with anaerobic bacteria to produce biogas. This process produces Biogas containing approximately 60:40 mixtures of methane $\left(\mathrm{CH}_{4}\right)$, and carbon dioxide $\left(\mathrm{CO}_{2}\right)$ and simultaneously generating an enriched sludge fertilizer- with an energy content of $22.5 \mathrm{MJ} / \mathrm{m}^{3}$. In Anaerobic digestion (AD) the organic fraction of municipal solid waste offers the advantage of both a net energy gain by 
producing methane as well as the production of a fertilizer from the residuals (Edelmann, $\mathrm{W}$ et al 2000).

Landfill gas recovery: The waste deposited in a landfill gets subjected, over a period of time to anaerobic conditions and its organic fraction gets slowly volatilised and decomposed. This leads to production of landfill gas containing about $45-55 \%$ methane, which can be recovered through a network of gas collection pipes and utilised as a source of energy.

\section{Thermochemical conversion:}

Incineration- is one of the most effective means of dealing with many wastes, which reduces their harmful potential, and often to convert them to energy form (Tchobanoglous, et al 2002). Incineration is the controlled burning of waste in a purpose built facility. It involves the process of direct burning of wastes in the presence of excess air at the temperatures of about $800^{\circ} \mathrm{C}$ and above (The Expert Committee, 2000). The process sterilizes and stabilises the waste. For most wastes, it will reduce its volume to less than a quarter of the original. Most of the combustible material is converted into ash and carbon dioxide (Sathishkumar, et al 2002). In practise, about $65-80 \%$ of the energy content of the organic matter can be recovered as heat energy, which can be utilised either for direct thermal applications, or for producing power.

Pyrolysis: is also referred to as destructive distillation or carbonisation. It is the thermal decomposition of organic matter at high temperature (about $900^{\circ} \mathrm{C}$ ) in an inert (oxygen deficient) atmosphere or vacuum, producing a pyroligenous liquid having high heat value and is a feasible substitute of industrial fuel oil.

Gasification: involves thermal decomposition of organic matter at high temperatures in presence of limited amounts of air/oxygen, producing mainly a mixture of combustible and noncombustible gas (carbon monoxide, hydrogen and carbon dioxide). This process is similar to Pyrolysis, involving some secondary /different high temperature $\left(>1000^{\circ} \mathrm{C}\right)$ chemistry which improves the heating value of gaseous output and increases the gaseous yield (mainly combustible gases $\mathrm{CO}+\mathrm{H}_{2}$ ) and lesser quantity of other residues. 
Depending on the physical and chemical characteristics of the waste the treatment process can be chosen. In table 5 the desirable range of important waste parameters for each process is given.

Table 5: Desirable range of important waste parameters for technical viability of energy recovery

\begin{tabular}{|c|c|c|c|}
\hline Waste treatment method & Basic principle & $\begin{array}{l}\text { Important waste } \\
\text { parameters }\end{array}$ & $\begin{array}{l}\text { Desirable } \\
\text { range }\end{array}$ \\
\hline \multirow{5}{*}{$\begin{array}{l}\text { Thermo-chemical } \\
\text { conversion } \\
\text { • Incineration } \\
\text { - Pyrolysis } \\
\text { - Gasification }\end{array}$} & \multirow{5}{*}{$\begin{array}{l}\text { Decomposition of organic } \\
\text { matter by action of heat }\end{array}$} & Moisture content & $<45 \%$ \\
\hline & & $\begin{array}{l}\text { Organic/volatile } \\
\text { mater }\end{array}$ & $>40 \%$ \\
\hline & & Fixed carbon & $<15 \%$ \\
\hline & & Total Inerts & $<35 \%$ \\
\hline & & $\begin{array}{l}\text { Calorific value (Net } \\
\text { calorific value) }\end{array}$ & $\begin{array}{l}>1200 \mathrm{k}- \\
\mathrm{cal} / \mathrm{kg}\end{array}$ \\
\hline \multirow{3}{*}{$\begin{array}{l}\text { Biochemical conversion } \\
\text { Anaerobic digestion/ Bio- } \\
\text { methanisation }\end{array}$} & \multirow{3}{*}{$\begin{array}{l}\text { Decomposition of organic } \\
\text { matter by microbial action }\end{array}$} & Moisture content & $>50 \%$ \\
\hline & & $\begin{array}{ll}\text { Organic } & \text { volatile } \\
\text { matter } & \end{array}$ & $>40 \%$ \\
\hline & & $\mathrm{C} / \mathrm{N}$ ratio & $25-30$ \\
\hline
\end{tabular}

Source (The Expert Committee, 2000)

\subsubsection{Transfer and transport}

This involves two steps:

The transfer of wastes from smaller collection vehicle to larger transport vehicle and, the subsequent transport of the wastes usually over long distances, to a processing or disposal site. The transfer usually takes place at a transfer station.

\subsection{Disposal}

Non-engineered disposal: This is the most common method of disposal in low-income countries, which have no control, or with only slight or moderate controls. They tend to remain for longer time and environmental degradation could be high, include mosquito, rodent and water pollution, and degradation of the land.

Sanitary Landfill- is a fully engineered disposal option, which avoids harmful effects of uncontrolled dumping by spreading, compacting and covering the wasteland that has been carefully engineered before use. The four minimum requirements for setting up a sanitary 
landfill are full or partial hydrological isolation, formal engineering preparation, permanent control and planned waste placement and covering. Land filling relies on containment rather than treatment (for control) of wastes. Appropriate liners for protection of the groundwater, leachate collection and treatment, monitoring wells and appropriate final cover design are integral components of an environmentally sound sanitary landfill

\subsection{Municipal Solid Waste Management systems in India}

\section{The Stakeholders involved in the management of MSWM are:}

- The Ministry of Environment and Forests: The Ministry of Environment and Forests is responsible for general aspects related to waste management, and draws up, coordinates the environmental policy and overseas the implementation of the federal legislation regarding waste management.

- Central Pollution Control Board: Coordinate the activities of the State Pollution Control Boards and provide technical assistance and training to the personnel. Disseminate information sponsor research relating to waste management. To perform functions prescribed by the Government.

- State Pollution Control Board: Plans a comprehensive program for the prevention, control or abatement of air pollution and water pollution. To inspect, at all reasonable times, any control equipment or process. Prior to installation of a landfill or incinerator, permission from SPCB must be obtained.

- City Corporation: City Corporation issues permits and creates policy for waste management. Provides waste management services or operates disposal, recycling, or composting facilities. Often contracts out services to the private sector. 
- Private Formal Sector: Private Formal Sector- participates in performing the functions of collection and transportation of the waste and may operate disposal, transfer, and recycling facilities

- Private Informal Sector: Private Informal Sector - collection of the recyclable waste, transfer to the recycling facility and recycling of waste

- Donor Agency: Donor Agency- helps in sponsoring of innovative projects and projects in low-income areas.

- Service Users- the people who use the service of municipal waste management

The municipal waste management system involving the stakeholders and the relationship between these stakeholders has been represented in Figure2. 
Figure 2: Municipal Solid Waste Management System in India

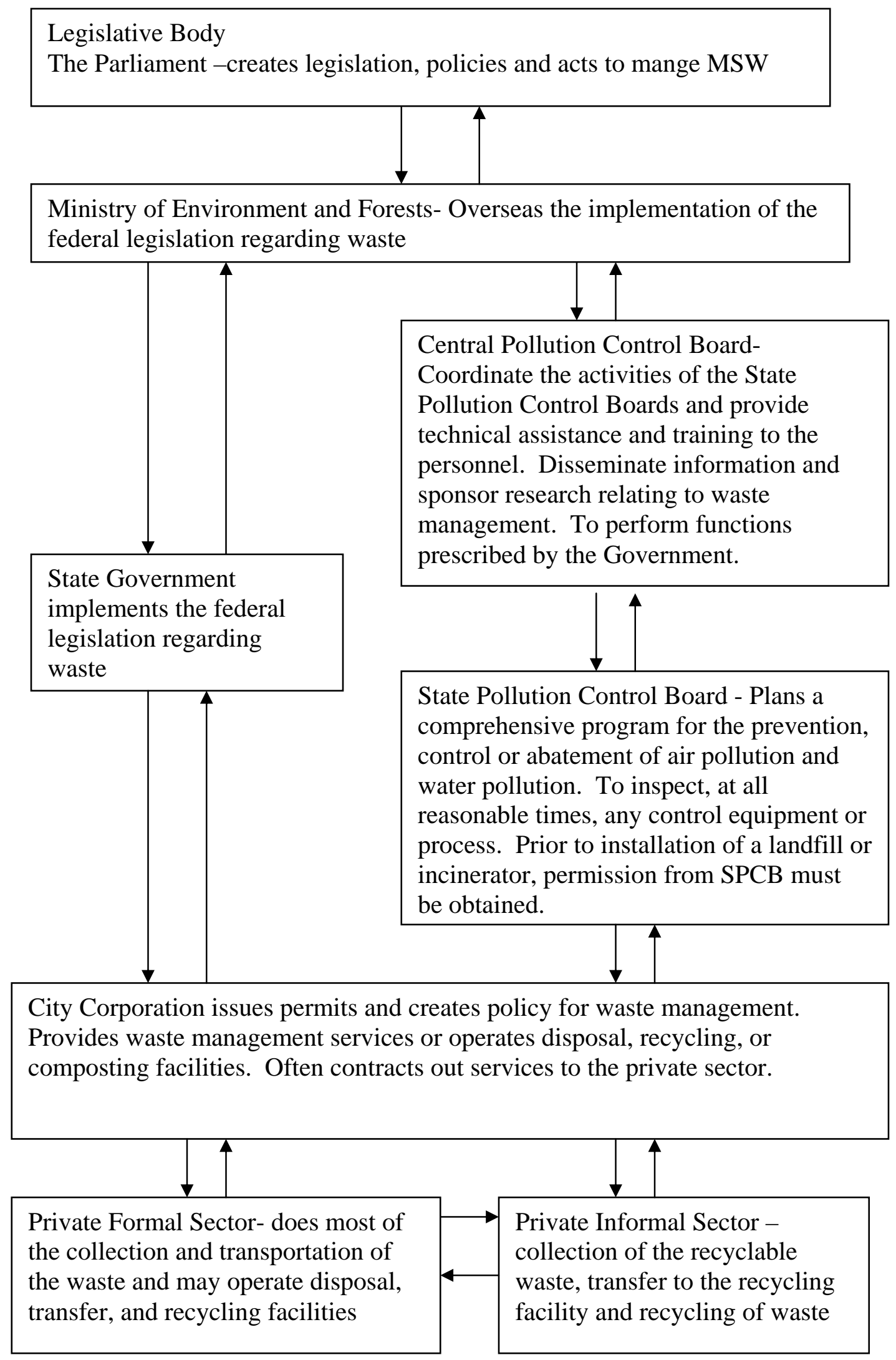




\section{STUDY GOALS}

The improvement of solid waste management is one of the greatest challenges faced by the Indian Government. The Government and the local municipal authorities have taken many initiatives towards the improvement of the current situation. The private sector has been included in the management of the municipal solid waste recently. To understand the level of success in these initiatives, it is necessary to carry out an audit. An audit will identify and bring out the lacuna and the loopholes in the current system in regard to various environmental management aspects like the compliance with environmental regulations, occupational health, resource management, pollution prevention systems and occupational health and safety. This could be one of the best ways to increase awareness about the most suitable approaches to municipal solid waste management, the issues likely to be faced and the alternative measures that can be adopted considering the local scenario.

This work provides a case study on an audit of the municipal solid waste management in Bangalore city, to disseminate the innovative practices that have been adopted in the municipal solid waste management program. The study will explore the role of various stake holders in MSWM, the current practices, the role of each entity, the shortcomings of the current practices and issues to be addressed to improve the condition.

\subsection{Objective}

Auditing of Municipal Solid Waste Management (MSWM) involved the following objectives

- To review the existing municipal solid waste management practices

- To audit the municipal solid waste management practices considering a case of Bangalore city. 


\subsection{Relevance}

Regarding solid waste management in particular, there has been improvement in the interest, research and expertise in integrated approaches in developing countries; however, there is a lack of information about local initiatives (Furedy 1997). There is a need for information to be shared, systems to be evaluated, and difficulties to be discussed (Furedy 1997). This study addresses several research needs by providing a case study that has been evaluated in comparison with environmental management concepts, thereby helping to increase general understanding of solid waste management in India. The case study of audit of the management system reflects the system's specific history, context and conditions, the sharing of experiences and lessons learned which may be of use to others to increase understanding of solid waste management in developing countries, and inspire the development of ideas and actions. 


\section{LITERATURE REVIEW}

Developed countries have provided technical assistance in SWM to developing countries focusing SWM as a technical problem with an assumption that solid waste problem can be solved with machineries (Lardinois, et al 1997). The "blind technology transfer" of machinery from developed countries to developing countries and subsequent failure has brought attention to the need for appropriate technology (Beukering, et al, 1999) to suite the conditions in developing countries (type of waste, composition, treatment, etc.).

Table 6: Difference between Developed and developing nations affecting the waste management plan

\begin{tabular}{|c|c|c|}
\hline Concern & Developed countries & Asian developing Countries \\
\hline \multirow[t]{2}{*}{ Global Implication } & \multirow[t]{2}{*}{ Global climate change } & Reduction of Imports \\
\hline & & $\begin{array}{l}\text { Protection of entry of toxic al } \\
\text { hazardous waste }\end{array}$ \\
\hline conomics of operation & & \\
\hline \multicolumn{2}{|c|}{$\begin{array}{l}\text { Concern about Meeting recycling targets } \\
\text { management alternatives }\end{array}$} & te \\
\hline ttul & Temperate zone & Warm and moist tropics \\
\hline aste characteristics & \multicolumn{2}{|c|}{$\begin{array}{c}\text { High percentage of paper, High percentage of organic waste, } \\
\text { plastics and cans } \\
\text { variation of moisture content } \\
\text { (seasonal) and combustible }\end{array}$} \\
\hline echnology choice & \multicolumn{2}{|c|}{$\begin{array}{l}\text { Environmental safe alternative, Low cost alternatives complying to } \\
\text { development- oriented decision regulations }\end{array}$} \\
\hline \multirow{2}{*}{\multicolumn{3}{|c|}{$\begin{array}{l}\text { Citizens and Years of learning from Lack of experienced and traine } \\
\text { Government Interface } \\
\begin{array}{l}\text { experience, high educational personnel, low level of environmenta } \\
\text { level of citizens }\end{array}\end{array}$}} \\
\hline & & \\
\hline \multicolumn{2}{|c|}{$\begin{array}{l}\text { Emphasis of urban Amenity } \\
\text { planning and design }\end{array}$} & Health \\
\hline \multicolumn{2}{|c|}{ Describe level of service Good } & $\begin{array}{l}\text { Makeshift measures, response } \\
\text { complaints }\end{array}$ \\
\hline
\end{tabular}

Modified from Fernandez, 1997

India has had its own set of experiences by adopting methods and using technologies from developed nations. The management of MSW in developing countries like India has to be looked at from a different perspective. The tried and tested methods adopted in developed 
countries cannot be blindly implemented. This section documents SWM with reference to India, methods and technologies adopted for each functional element.

\subsection{Municipal Solid Waste Management in India}

In India, according to the Ministry of Environment and Forests "municipal solid waste" includes commercial and residential wastes generated in municipal or notified areas in either solid or semi-solid form excluding industrial hazardous wastes but including treated bio-medical wastes (MoEF, 2000). In simple words the municipal solid waste can be defined as the waste that is controlled and collected by local authority and municipality.

Municipal Solid Waste Management in India falls under the public health and sanitation and hence as per the Indian Constitution is a State responsibility. This service has always been within the public domain until very recently, that the waste management services started being privatised. The activity being local in nature has been given to local municipal authorities that provide this service with its own staff, equipment and funds.

The Government of India (GoI) has encouraged the proper management of MSW from as early as 1960s when the Ministry of Food and Agriculture gave soft loans to the local municipal authorities for MSWM. GoI also gave grants and loans to state government for setting up MSW composting facilities under the fourth five-year plan (1969-74)(Beukering, 1999). In 1974 GoI modified this scheme making it specific only for cities having a population above 30 lakhs. The Water (prevention and Control of Pollution) Act of 1974 resulted in the creation of Central and State Pollution Control Boards (CPCB and SPCB) with the aim of prevention, abatement and control of water pollution. The Air (Control and Prevention of Pollution) Act of 1981 also empowered the CPCB and SPCB (Harashima, 2000). These Boards now authorise process plants and sanitary landfill sites. 
A high level committee was set in 1975 to review the problems of urban solid waste in India. This committee covered all aspects of waste management and based on these recommendations, between 1975 and 1980, ten mechanical compost plants were set up in the country. Out of all the plants commissioned there is only one functional at Bangalore. A major step in the direction of managing waste happened with GoI setting up of the National Waste Management Council (NWMC) in 1990. This council provided financial assistance to 22 municipalities to undertake surveys to assist them in improving the MSWM situation (Marandi, 1998).

After the outbreak of the plague epidemic in Surat, the magnitude of the problem was realised by the government. A high powered committee was set up in 1995 which gave many recommendations for the improvement of MSWM like door to door collection, setting up of transfer stations, charging user fees, etc. The ministry of Environment and Forests (MoEF) and СPCB held meeting with the municipalities to evolve a strategy for MSWM. About 50 waste treatment facilities were set up after this. In 1996, the MNES initiated a pilot program to promote waste-to-energy projects in India, which may be considered as the birth of the new era of waste-to-energy programs in India.

In India, according to the Ministry of Environment and Forests "municipal solid waste" includes commercial and residential wastes generated in municipal or notified areas in either solid or semi-solid form excluding industrial hazardous wastes but including treated bio-medical wastes (MoEF, 2000). In simple words the municipal solid waste can be defined as the waste that is controlled and collected by local authority and municipality.

As per the recent estimates, the country produces about 100000 MT urban solid waste daily (The Expert Committee, 2000) with typical characteristics as per the Table 1 below. The municipal waste generation in metro cities varies between $0.2-0.6 \mathrm{~kg} / \mathrm{capita} / \mathrm{day}$ (Zurbrugg, 2002 and Agarwal, et al 2005), and urban MSW generation is estimated to be approximately $0.49 \mathrm{~kg}$ per capita per day. This is estimated to be two or three times more than the waste generated by rural residents (Devi, et al 2001). The figures, however, vary from city to city. For example, while the per capita waste generated in Delhi is $0.5 \mathrm{~kg}$ per day, MSW generated per capita per day is $0.35 \mathrm{~kg}$ in Hyderabad and $0.64 \mathrm{~kg}$ in Bangalore (Huysman, 1994). According 
to studies carried out by (NEERI) the per capita waste generated in a typical Indian metropolitan city increases by $1.3 \%$ per year while the estimated urban population growth is around 3.5\% per annum (Shekdar, et al 1993). These studies point out that there is a large difference between urban and rural level of waste generation, which reflect the economic extremities existing with the Indian society.

Many studies have been conducted to estimate the composition of waste in Indian cities, as it is an important parameter in choosing the process method to be adopted and the design of the process plant. The studies reveal that the organic fraction of the waste makes up $40-75 \%$ of the waste (National Solid waste Association of India, 2003, CPCB, 1998 and NEERI, 2000). Studies have stated that the composition of waste varies depending on the income and life style (Zurbrugg, 2004).

Table 7: Physical Characteristics of a typical city Municipal Solid Waste

\begin{tabular}{llllllll}
\hline Population & Number & Paper & Rubber, & Glass & Metals & Total & Inert (\%) \\
range & of cities & $(\%)$ & Leather & $(\%)$ & $(\%)$ & compostable & \\
(million) & surveyed & & and & & matter (\%) \\
& & & Synthetics & &
\end{tabular}

(\%)

\begin{tabular}{llllllll}
\hline 0.1 to 0.5 & 12 & 2.91 & 0.78 & 0.56 & 0.33 & 44.57 & 43.59 \\
0.5 to 1.0 & 15 & 2.95 & 0.73 & 0.35 & 0.32 & 40.04 & 48.38 \\
1.0 to 2.0 & 9 & 4.71 & 0.71 & 0.46 & 0.49 & 38.95 & 44.73 \\
2.0 to 5.0 & 3 & 3.18 & 0.48 & 0.48 & 0.59 & 56.67 & 49.07 \\
$>5$ & 4 & 6.43 & 0.28 & 0.94 & 0.80 & 30.84 & 53.90 \\
\hline
\end{tabular}

Source: The Expert Committee (2000) Manual on Municipal Solid Waste Management, The Ministry of Urban Development, The Government of India1.

From table 7 we can deduce that in India the overall percentage of inert material in all cities is very high. This can cause hindrance to processes like incineration and anaerobic digestion if the waste is not segregated prior to processing. The percentage of compostable matter is high in all 
cities, but the cities with a population above five million have a lower percentage of organic matter compared to the cities with a lower population. The cities with a population above 5 million also have a higher percentage of paper and glass material. The cities in India having a population higher than 5 million are also having high income. The waste composition also indicates the same.

Table 8: Chemical characteristics of Municipal Solid Waste in Indian Cities

\begin{tabular}{lllllllll}
\hline $\begin{array}{l}\text { Population } \\
\text { range (in } \begin{array}{l}\text { No of } \\
\text { million) }\end{array}\end{array}$ & $\begin{array}{l}\text { surveyed } \\
\text { sitisture }\end{array}$ & $\begin{array}{l}\text { Organic } \\
\text { matter }\end{array}$ & $\begin{array}{l}\text { Nitrogen } \\
\text { as Total } \\
\text { Nitrogen }\end{array}$ & $\begin{array}{l}\text { Phosphorus } \\
\text { as } \mathrm{P}_{2} \mathrm{O}_{2}\end{array}$ & $\begin{array}{l}\text { Potassium } \\
\text { as } \mathrm{K}_{2} \mathrm{O}_{2}\end{array}$ & $\begin{array}{l}\mathrm{C} / \mathrm{N} \\
\text { ratio }\end{array}$ & $\begin{array}{l}\text { Calorific } \\
\text { value in } \\
\mathrm{kcal} / \mathrm{kg}\end{array}$ \\
\hline $0.1-0.5$ & 12 & 25.81 & 37.09 & 0.71 & 0.63 & 0.83 & 30.94 & 1009.89 \\
$0.5-1.0$ & 15 & 19.52 & 25.14 & 0.66 & 0.56 & 0.69 & 21.13 & 900.61 \\
$1.0-2.0$ & 9 & 26.98 & 26.89 & 0.64 & 0.82 & 0.72 & 23.68 & 980.05 \\
$2.0-5.0$ & 3 & 21.03 & 25.60 & 0.56 & 0.69 & 0.78 & 22.45 & 907.18 \\
$>5.0$ & 4 & 38.72 & 39.07 & 0.56 & 0.52 & 0.52 & 30.11 & 800.70 \\
\hline
\end{tabular}

Source: The Expert Committee, 2000. Manual on Municipal Solid Waste Management. The Ministry of Urban Development, The Government of India 1.

From table 8, we can deduce the Indian waste has a high content of organic matter, which makes it suitable for processes like composting and anaerobic digestion. The $\mathrm{C} / \mathrm{N}$ ratio is between 2030 and this ratio is very suitable for composting (Eiland, et al, 2001). The waste also has a high moisture content which makes it unsuitable for incineration.

Table 9: Density of Municipal Solid Wastes in some Cities

\begin{tabular}{lll}
\hline Sl.No. & City & Density $\left(\mathrm{Kg} / \mathrm{m}^{3}\right)$ \\
\hline 1. & Bangalore & 390 \\
2. & Baroda & 457 \\
3. & Delhi & 422 \\
4. & Hyderabad & 369 \\
5. & Jaipur & 537 \\
\hline
\end{tabular}




\begin{tabular}{lll}
\hline 6. & Jabalpur & 395 \\
7. & Raipur & 405 \\
\hline
\end{tabular}

Source: The Expert Committee (2000) Manual on Municipal Solid Waste Management, The Ministry of Urban Development, The Government of India, Volume 1 and 2

Density is another important factor that needs to be estimated as it is essential for the design considering all functional elements of solid waste management system viz. Community storage, transportation and disposal. In India, the waste collection vehicle is not weighed in order to estimate the weight; only the number of trips made is counted. This is not appropriate as the density, tends to change from time to time (Shekdar, 1997).

\subsubsection{Storage}

Municipal Solid Waste is commonly stored in circular concrete open bins in India. There have hardly been any studies conducted on the most suitable type of storage bin for the Indian waste. The waste should be preferably stored in closed bins and for not more than 24hrs, as the Indian waste has high organic content and is highly putricible.

\subsubsection{Collection}

The waste collection methods that are mainly adopted in India are Door to door collection and Community method. Community bin method has been the most commonly adopted method in India. A study carried out in Indian Institute of Science (Sathishkumar, et al, 2002) describes that in community bin method, the improper placement of bins, bins not designed as per quantity of waste generated and bins not being covered causes problems like odour, stray dog nuisance and unaesthetic appearance.

On the other hand, a study conducted on municipal solid waste management describes the collection of waste by Door-to-Door method in Ahmedabad (Sachdeva, 2002). Here the worker uses a pushcart with 6 drums for the separate collection of waste. The householder has to collect 
the dry waste in plastic bags and biodegradable waste in bins. The worker collects the waste and put it in separate bins. This is then transferred into large storage containers, which are designed as per the population density. The same system has been adopted in Chennai (IPE, 2004). In From these studies, it has been observed that the door to collection method has improved the efficiency of collection of segregated waste.

The collection efficiency ranges between 70 to $90 \%$ in major cities whereas in several smaller cities the collection efficiency is below 60\%. Street sweeping is another type of collection method for the collection of street litter; many cities spend 30-50 \% of their solid waste budgets on street cleansing (The Expert Committee, 2000).

Studies show that in most urban areas it is the slums and areas where the poorer communities reside which are most badly served (Fritz, 1990 and Furedy, 1994). One possible reason could be that municipal authorities give priority to localities where the elite and the better-off populations reside because of their influence and political weight. Meanwhile, the areas which are not serviced are faced with clogged sewers and littered waste, creating serious health problems for the resident population.

\subsubsection{Transfer and Transport}

Many methods have been adopted for the transfer of waste from either the pushcarts to trucks or Bins to truck. In Ahmedabad, door-to-door collection method is adopted. Here once the waste is collected in pushcarts, it is transferred to large covered metal bins having separate compartments for storage of segregated waste. From here it is transferred to the trucks with a mechanized collection truck that lifts the container and empties the waste into the truck (Sachdeva, 2004). This mechanism adopted in Ahmedabad is new and can be found only in select cities in India. The most common method for transfer is manual transfer from community bin to trucks by 2 to 3 workers (The Expert Committee, 2000). The transfer of waste directly from pushcarts to trucks by meeting at a specified time and place called synchronization points is suggested by (Karadimas, 2004), which is a suitable option for the door to door collection method. 
Transportation of waste is carried out by the municipalities employing vehicles like open trucks, tractor-trailers, tipper trucks and dumper placers. According to calculations done on a basis of waste density, waste generated etc. indicate that on an average $320 \mathrm{~m}^{3}$ capacity is required for daily transportation of waste generated by 1 million population. However, a study carried out in 1996 stated that out of the 44 cities that were studied, $70 \%$ of these cities did not have $320 \mathrm{~m}^{3}$ transport capacity (Boyar, et al 1996). Many improvements have been made since then including the introduction of container-carriers and dumper-placers that was done by 1997 (Gupta, et al 1998). Bangalore itself has about 13 dumper placers (Ramachandra, et al, 2003) that do two trips a day.

\subsubsection{Process}

\subsubsection{Recycling}

The recycling sector in India has been in operation since the 1960's and while only a fraction of the total plastic waste is being recycled in most western countries (APME, 1995), around $75 \%$ of the plastic wastes are recycled in India (Haque, 1998). Rag pickers mainly carry out the recycling process in India and they play a vital role in the economy of solid waste recycling process (Agarwal, et al 2005). They feed the need of the intermediary buyers, who, in turn, meet the demand of factories using recyclable solid waste as raw materials. However, the rag pickers do not have sufficient protection and are exposed to waste and sometimes even the hazardous waste present in MSW. A study carried out in 2003 has shown that 75 percent rag pickers have upper and lower respiratory symptoms (Bhattacharya, 2005). Even the quality of the successively recycled products in the informal sector in terms of their (i) physical appearance (ii) polymeric properties (iii) health hazards (for the recyclers and users of such products involved) are in serious question (Haque, 2000).

Another aspect to be noted is that plastic carry bags and PET do not figure in the list of priorities for rag pickers, because collecting them is not profitable. This is primarily because the rewards do not match the efforts required for collection, and this leads to plastic bags and PET continuing to pose a major threat to the environment (Narayan, 2001). 


\subsubsection{Composting}

Composting urban waste in India has a long history. Sir Albert Howard developed the Indore process nearly 75 years ago by systemizing the traditional process that was carried out in India (Howard, 1940). Government intervention to promote this practice can be traced to the 1940s and the early 1970s, when the national government initiated a scheme to revive urban composting (Selvam, 1996). However, centralized large-scale composting plants in urban areas promoted in the 1970s proved to be uneconomical (Dulac, 2001). Only a few installations are currently still operational (UNDP, 1991). Due to high operating and transport costs and the poorly developed market for compost, the expected profits could not be realized as planned. Composting of mixed waste also had a negative effect on compost quality and, thus, on its acceptance by farmers.

From 1990's decentralized composting schemes have been implemented by NGO’s with the help of international funding. The decentralized composting schemes became very popular and widespread in a short span of time. Various types of composting have been adopted by these schemes e.g. Bin-composting, Shallow windrow, Pit composting and vermicomposting. However, the maintenance of such schemes proved to be difficult because the household involvement was sporadic, as many people believe that it is the municipal corporation's responsibility to collect waste and do not want to make additional payments. This study states that though decentralized composting has more advantages than centralized composting, the market for MSW compost is limited and is rarely financially competitive to heavily subsidized chemical fertilizers and traditional cow dung or poultry manure (Zurbrügg, et al 2002).

However, in Class II, Class III and Class IV cities an urban agricultural set up exists and functions, where there is optimal use of municipal solid waste. The farmers buy the organic waste from the municipality at very low costs and use it as manure. There are also companies that have taken over the responsibility segregating, decontaminating and composting MSW. This high quality compost is then sold to the farmers at a very high cost compared to the raw MSW. It has been observed that the farmers prefer the raw MSW to the processed high quality compost, because the latter is too expensive (Nunan, 2000). 
Currently, there are few large-scale composting plants around India that are running successfully. For e.g. composting plant in Hyderabad run by AP technology development and promotion center (intake of 200MT/day, composting plant in Vijaywada by Exel industries (intake of 125 MT/day), composting plant in Bangalore by Karnataka Compost Development Authority (KCDC)(intake of 300MT/day) and composting plant in Bangalore by Terra Firma Biotechnologies (100MT capacity). All these compost plants have a high demand for their products and want to increase their processing capacity to meet the huge demand. The awareness for organic manure is increasing rapidly in India that will in turn increase the demand for the manure produced from MSW (Garibay, et al, 2003).

\subsubsection{Anaerobic Digesters}

Biogas is a successful renewable energy technology developed and disseminated in India, second only to improved wood stoves in its spread. Biogas was first introduced to India as an alternative to piped natural gas in 1897 for providing gas-based illumination (Sathianathan, 1990). The superiority of biogas slurry both as manure as well as compost starter and the cleanliness of the process has been emphasized in several publications of the Indian Agricultural Research Institute (IARI) and other agricultural institutions in the country (Chanakya, et al 2002). However, biogas production has been restricted mostly to rural areas (with cattle dung) and in urban areas (with sewage). The anaerobic digesters used in the rural areas are simple in design and to maintain, but they require constant monitoring and are less efficient. The complex digesters on the other hand, are designed to automatically adjust when environmental conditions change, such as would occur with the feedstock. These are used in developed nations to treat unpredictable waste flows and such digesters would be suitable for processing of MSW (Ostrem, et al, 2004). Many studies have been conducted on the use of MSW for production of Biogas. One of the studies suggests that by having decentralized anaerobic digesters in the localities, the odour problem caused by MSW from bins and during long transportation distances can be minimized (Chanakya, et al, 2002). Apart from this (Srinivasan, 2003, Ramasamy, 2000 and Ostrem, et al, 2004) bring out the dual purpose of anaerobic digesters, not only will they provide a solution to the solid waste crisis, but also to the energy crisis. 
In India, not many large-scale biomethanisation plants using MSW have been set up. One of the few biomethanation plants set up was in Lucknow that consumed $300 \mathrm{MT} /$ day of MSW to generate $75 \mathrm{MT} /$ day of organic manure and 5.1 MW of electricity. This plant was recently shut down, and the main cause for failure was the intake of unsegregated waste (Gopalakrishna, 2005).

\subsubsection{Incineration}

Incineration is another alternative for waste processing that is being used in India. Waste combustion is not a common practice in India. One 120 tonne per day incinerator was built during the 1930s in Calcutta but was operated for only a short period. After this study a Danish incinerator-cum-power plant was installed at Timarpur in North Delhi and was shut down in 1985 due to high maintenance cost. An extensive sample program conducted in India by (Bhide, 1984) reveals that most of the waste had a calorific value of just 3350 joules/g compared with 9200joules/g in high-income countries (Sathiskumar, 2002). Incinerators have been reintroduced in India for energy recovery from municipal solid waste. Recently, the Chennai Municipality had approved a plan to set up a 14.85 MW waste-to-electricity plant at Perungudi. But, due to the opposition of environmentalists the project did not take off (Hindu, 2005). However, in Hyderabad, a private company Selco has set up an incinerator that is running successfully by converting waste to electricity. It takes in 400 tonnes for generating $6 \mathrm{MW}$ of power that is being fed into the grid of the Transmission Corporation of Andhra Pradesh (APTransco) (UNDP, 2000 and Hindu, 2004).

The main draw back identified for the use of incinerators and anaerobic digesters for processing MSW is that the waste is not segregated prior to the process. 


\subsubsection{Disposal}

Uncontrolled landfilling has been mainly adopted for ultimate disposal of municipal solid waste in India; thereby causing numerous health, environmental and aesthetic hazards (Ambulkar, 2004). However, now landfilling is the most preferred method of disposal of solid wastes as it is an effective and low cost method of disposal (Nissim, 2005). Onionskin method of lying i.e., alternate building rubbish of thickness $30 \mathrm{~cm}$ and municipal waste with thickness of 1 to $3 \mathrm{~m}$ is adopted in few cities like Delhi, Chennai and Hyderabad (CPCB, 1998). However, the number of sanitary landfills are extremely low compared to the dumpsites, where uncontrolled dumping is observed, leveling and provision of earth cover is rarely provided. The rag pickers are further observed to be active at disposal site. Methane gas that is emitted at the landfills is not collected, hence adding to the GHG emissions (Kumar, S., et al 2004).

\section{2 Audit Municipal Solid waste Management}

Auditing has become an increasingly popular tool to assess the environmental policies, quality of implementation, compliance with national law and regulation etc. Auditing has also been widely used in India especially in industries. The most popular audits that are carried out in India are energy audits (TERI, 2002) followed by environmental management systems audit where waste minimization audit is an integral part (Mannan, 2002). Audits on Municipal waste Management in India is however are very limited. Developed countries have established an auditing institution and carried out audits on urban waste management with regard to performance, compliance, risk, monitoring, existence of waste policy, quality of implementation etc.

An audit was carried out by the Estonian Government to assess to what extent are the necessary conditions for the successful implementation of the waste wise policy in place. Reports and questionnaires were used for the audit and it was observed that the management had serious shortcoming such as insufficient finance in comparison to the goal, management lacked organization, no national waste management plan and poor monitoring (Linnas, 2001). Audit Institution of Costa Rica carried out an audit on the solid waste management in two municipalities. This audit had a multiple focus of pollution prevention system, management 
system and site audit. Since, the solid waste management in Costa Rica is under the Ministry of Health, Ministry of environment and energy. The audit was carried out by collection of reports, interviews, site surveys and partial questionnaires. The audit identified that the ministries were not integrated and that many of plans were repeated. The other findings were insufficient public awareness programs, no introduction of new methodologies and technologies, insufficient financial support received and improper monitoring (INTOSAT, 2002).

An audit was carried out by the audit institution of Paraguay on the Cateura dump in Asuncion. This audit focused on the environmental administration by the municipality, the public authority responsible for the dump and on the monitoring by the governmental supervision agency. The management and control of the dump was investigated with regard to national health legislation and technical regulations. Checklists and site surveys were used as tools for this audit. From this audit it was observed that there was no urban cleanliness plan charted out by the municipal authority, serious violations of the legislations, no proper monitoring by the supervision agency and delayed closure of the dump (INTOSAT, 2002).

Various methods have been used for MSWM auditing namely report collection and interviews for the audit of the management system, site survey was used for the audit of compliance with national law and regulation, health and safety, pollution prevention system. In this thesis all these techniques have been applied in the case study- Environmental audit of MSWM of Bangalore city. The various aspects that will be looked into are compliance with national law and regulation, occupational health and safety, operational risk, pollution prevention and resource management. 


\section{METHODS}

The research approach for the case study was mainly qualitative. Data collection methods included document/literature review, semi-structured interviews, checklists and observation. Information was gathered using a variety of methods to gain a better understanding of the situation, issues, perspectives and priorities.

Table 10: Resource Material

\begin{tabular}{ll}
\hline Census of India & Population census \\
\hline Bangalore Mahanagara Palike & $\begin{array}{l}\text { Bangalore ward map } \\
\text { Ward wise details } \\
\text { Number of pourakarmikas } \\
\text { Number of push carts } \\
\text { Number of lorries }\end{array}$ \\
Survey of India & $1: 50,000$ Toposheet (57 H/9 and 57 G/12) \\
Others & $\begin{array}{l}\text { EIA study on Mavallipura (Ramky Consultants) } \\
\text { EIA study on Mandur site (Wilbur Smith Associates Private } \\
\text { limited) }\end{array}$ \\
\hline
\end{tabular}

\section{Audit method}

Different types of audits was carried out to achieve various objectives

- Compliance audit was carried out to check if the current waste management process has been carried out as per the legislation

- Operational Risk Audit in combination with Pollution prevention Audit was carried out to check the frequency with which an environmental damage occurs and what is the consequence of it. The measures that have been taken against these possible environmental damages were verified.

- Resource Management Audit was carried out to check the quantity of water, energy and material resources used to carry out a process and if the process has been carried out by optimal utilization of resources 
- Occupational Risk Audit was carried out to verify if all the measures towards the safety of the staff have been taken

To achieve this in each topic a list of necessities were listed in a checklist in regard to the specific target and the presence and absence of each was marked.

Site survey for seven representative sample wards (Shivajinagar, Malleswaram, Koramangala, IISc, H.M T, Airport Road and Chikpet) in Bangalore city was carried out. A checklist was prepared prior to the visit to check the presence or absence of techniques used, safety measures adopted, compliance with regulatory measures and pollution prevention system adopted. Interviews of health Inspectors, workers and lorry drivers were done at the ward level to assist the checklist. The higher officials were interviewed to have a basic understanding of the structure of the system and how it is managed. The officials interviewed were the range health officers, zonal health officers, Chief health Officer and the Special Commissioner.

The interviews with the higher officials helped to understand the management system, their objectives and the strategies adopted that have proved to be efficient, the strategies that have failed and what are the issues that have been faced in implementing these strategies.

The Site surveys and ward level interviews helped to identify the lacuna in the ground level, to verify if the process is being carried out as expected at what are the lacuna and loop holes in each functional element.

Site visits to the Karnataka Compost development Authority, Terra Firma Biotechnologies, Betahalli dump yard, K. R. Puram dump yard and quarry site in Bomanhalli.

\section{Geographic Information System (GIS)}

Bangalore city base layer was prepared in consultation with Survey of India toposheet 59 H/9 and 59 G/12 (scale 1:50,000) using Mapinfo 6.0 (GIS software). Ward maps and city boundary maps were created with reference to the existing base layer. 


\section{Difficulties and limitations}

Time and financial constraints precluded the possibility of a more rigorous approach for data collection in Bangalore. There was a lack of data available in few aspects such as weight of waste generated and composition per ward, the trip record of trucks, etc. The site visits to the wards was not sufficient to get the exact picture of the process. It was difficult to identify all the open dumps and quarry sites used for disposal, as the authorities didn't have knowledge about the location of open dumps. Data on the informal sector was not obtained, as there was no 'single window' data source about them. 


\section{A Case Study- Environmental Audit of MSWM in Bangalore city}

The city of Bangalore, the State capital of Karnataka is located on the southern part of the Deccan Plateau near the border of two other South Indian states namely Tamil Nada and Andhra Pradesh. At an elevation of $900 \mathrm{~m}$ it is known for its mild, salubrious climate. Since 1980s, Bangalore has enjoyed the reputation of being one of the fastest growing cities in Asia (Dittrich, 2004). The Bangalore metropolitan area covers an area of $223 \mathrm{sq} \mathrm{km}$, and is the fifth largest city in India. It falls on latitudes $12.97^{\circ} \mathrm{N}$ and $77.56^{\circ} \mathrm{E}$. It has many industries and it is home to more than $30 \%$ of the IT companies in India. For many years, Bangalore has ranked first among the other Indian cities in terms of Image and popularity. However, with burgeoning population and increasing necessities of the IT sector, the local authorities are not being able to provide the necessary services like solid waste management, water supply, road maintenance etc to a satisfactory level. The authorities however have taken initiatives and measures to achieve compliance with regulations and reduce complaints from citizens especially in the MSWM sector. The case study would help to identify the positive measures taken by the authorities and the other stakeholders. This would help to identify techniques suitable for the present scenario, the lacuna or the loopholes in the adopted methods and the possible alternatives. 
Figure 3: Bangalore Ward Map

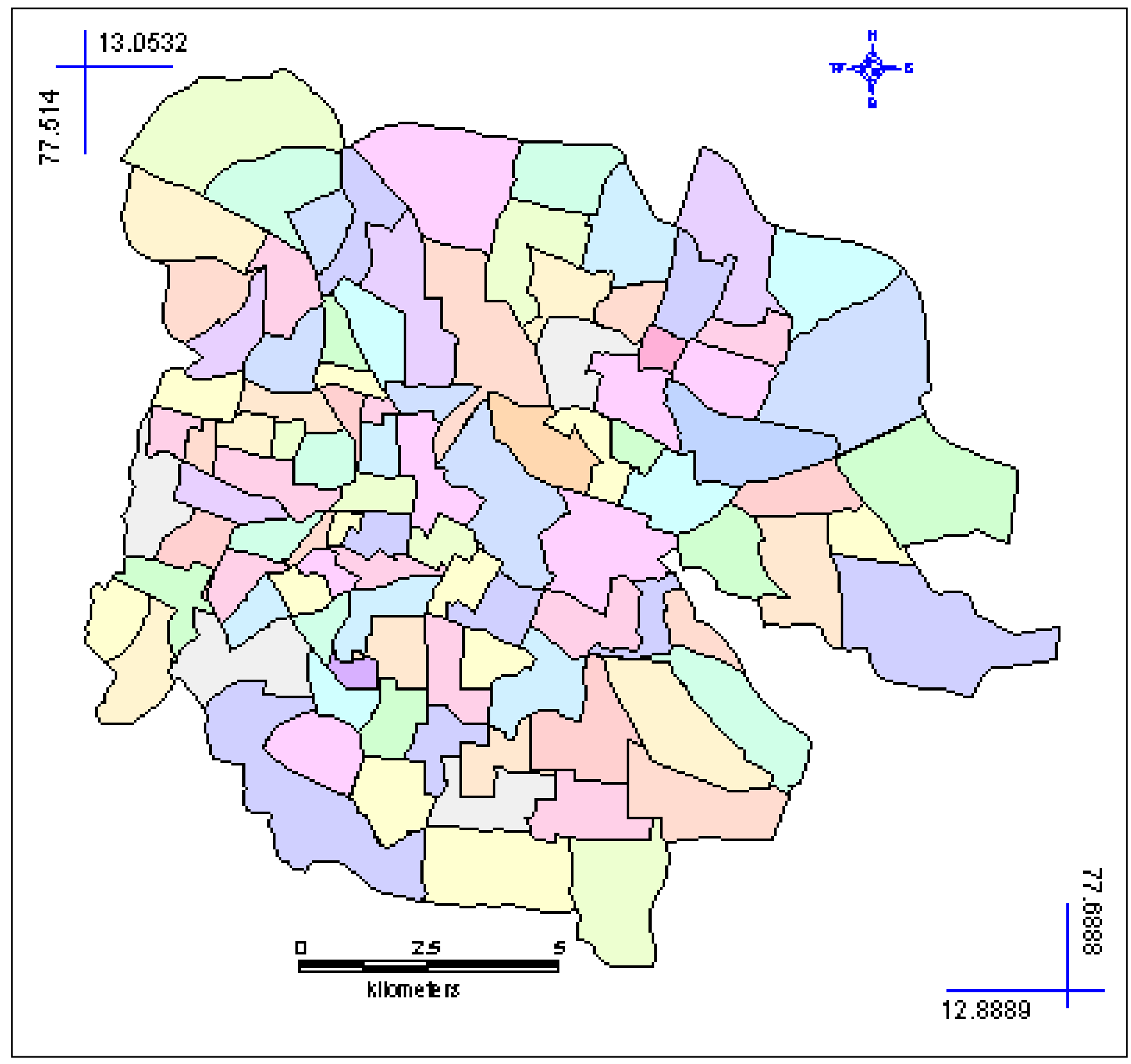


Figure 4: Bangalore map representing population density per ward

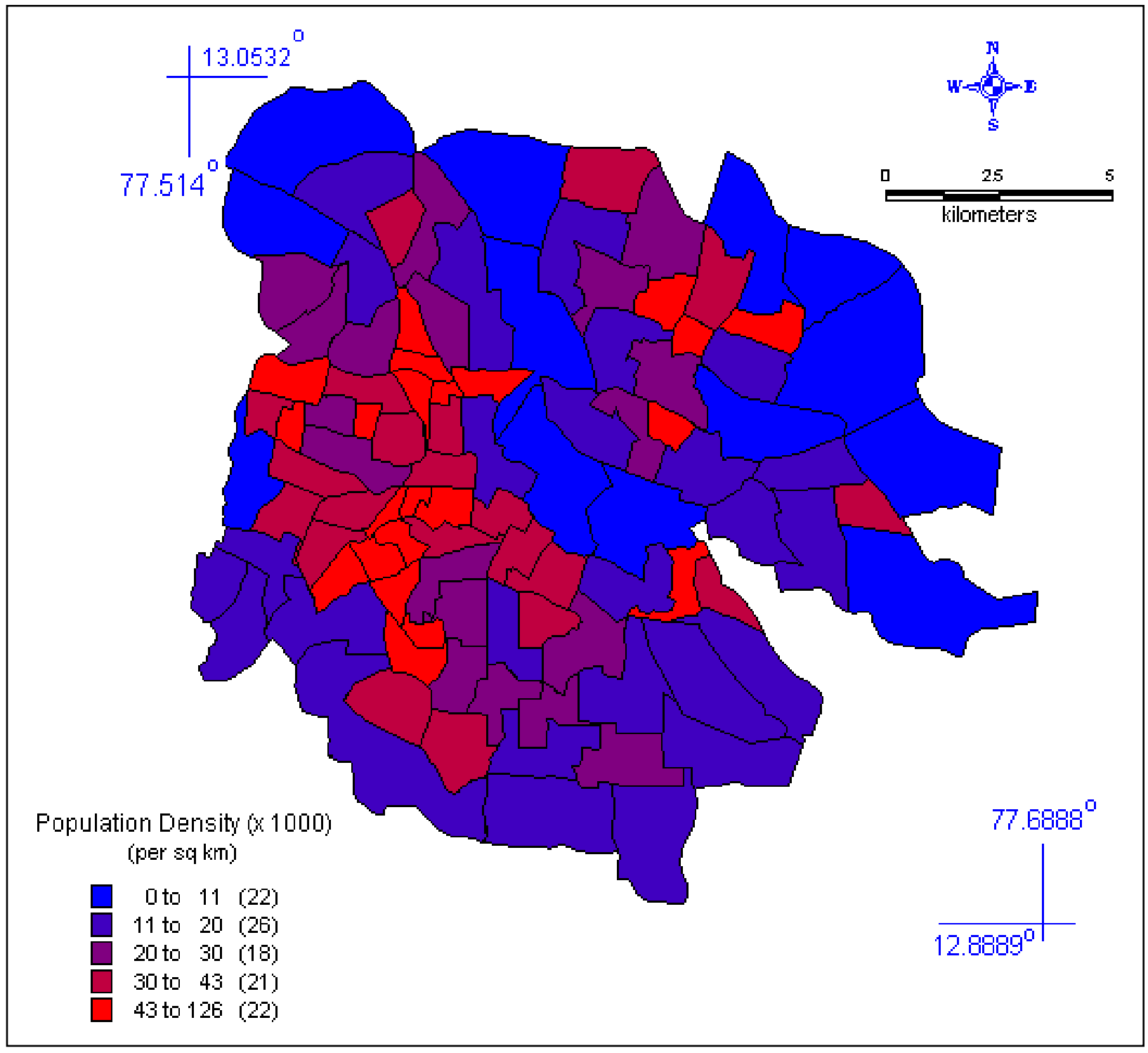




\subsection{Sanitation}

The Department of Health as a separate department was felt in 1887 when the Senior Surgeon was appointed as ex-officio Sanitary Commissioner. The out break of Plague in Bangalore in 1898 caused the creation of the post of the Health Officer for Bangalore City and the first health officer was appointed on Second October 1898. The health department was reorganized in 1907 with the appointment of whole-time Deputy Sanitary Commissioner in 1907. A central sanitary board and District sanitary board was organized for the improvement of Sanitation. In 1917 a full time Sanitary Commissioner was appointed. In 1929 the sanitary department was separated for the medical department and the department was named as the Health Department and the Sanitary Commissioner as the Director of Health. A central health committee was created. The Department of Health was divided into seven bureaux, the Bureau of Administration, the Bureau of Epidemiology and Communicable diseases, Bureau of Laboratories, Bureau of Vital Statistics, Bureau of Health Education, Bureau of Sanitary Engineering and the bureau of Rural Health.

The Sanitary conditions of the city prior to 1877 were irregular. The open drainage caused bad smell and there was only one sewage cart to dispose of the filth. Public health measures assumed much importance with the out break of plague in 1898. In March 1898, a loan was granted to the Bangalore Municipality by the Government for sanitary improvements, such as cleaning and repairing of drains, repairing of buildings, demolishing of dirty and unoccupied buildings, etc.

In June 1960, the curative and preventive services, which were separate till then, were amalgamated at the taluk level and below under the control of the District Health Officer and the Health and Medical department were combined into Directorate of Health services, each district being headed by a District Health Officer. The duties of the Health Officer consist of supervision and control of epidemics supervision of sanitary arrangements, examination of drinking water supply, health propaganda work, etc. He is responsible for all the health programmes, both National and State at the district level. The Bangalore City Corporation has its own heath department headed by the Health Officer to look after the sanitation and to carry out health programs in the city. 
District Health and Family Welfare: In 1988 the City Corporation Health Department was headed by the Health Officer, assisted by Four divisional health officers, two surgeons, 43 assistant surgeons, 15 medical officers, one chemical analyst, Aurvedic and Unani pandits one each, 30 lady medical officers, one senior biologist, one district health educator, 50 senior and 161 junior health supervisors, 34 lady health visitors, 13 managers and 9451 other staff including medical, para-medical, office staff and others. There were 6,851 Pourakamikas in the city.

\subsection{Ward Wise Population of Bangalore City Corporation, 2001}

Bangalore City Corporation with seven wards was formed in 1949 by merging two independent municipalities viz., Bangalore City and Bangalore Cantonment. Since then, the number of wards has been on the increase due to incorporation of surrounding areas on a continuous basis and also due to the ever-increasing population of the city. In the 1971 Census Bangalore City was divided into 63 wards, which remained the same in the 1981 Census. In the 1991 Census, Bangalore City had 87 wards and in the 2001 Census the number of wards has gone up to 100. The Bangalore City Corporation, which has 100 wards within its municipal jurisdiction, has a population of 4,292,223 accounting for 75.48 per cent of the total population of Bangalore Urban Agglomeration of which 2,240,956 are males and 2,051,267 are females. The decadal growth rate of population for the decade 1991-2001 for Bangalore City is as high as 61.36 per cent. This high growth rate can be attributed not only to the extension of the municipal limits of Bangalore City but also to the ever-increasing population. 


\subsection{Current MSWM practice in Bangalore City}

The current MSWM has been shown below in the flow chart and is explained in detail in the

Figure 5: Current MSWM practice in Bangalore city

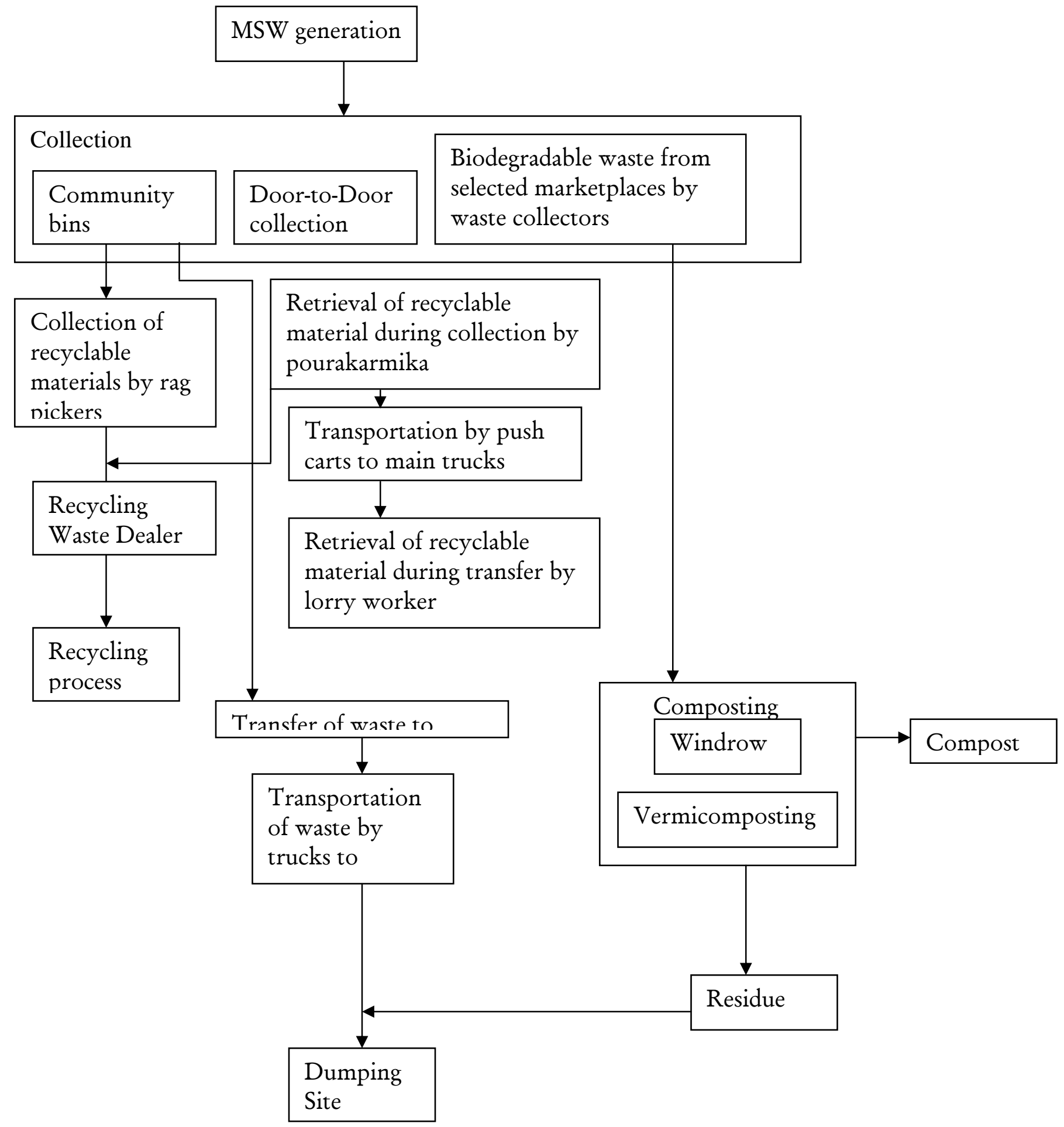


The Bangalore Metropolitan Area is on the whole divided into 30 ranges and 100 Revenue wards. For the proper management of the sanitation functions these wards have been further divided into 294 health wards. Out of these 294 health wards 112 are BMP wards and 182 are Contract wards. The budget allocation for MSWM is approximately Rs.70 crores per annum. There are 5000 employees and 7000 contract persons working in two shifts, their salaries alone cost the corporation 24 crores per annum. The amount of waste generated in Bangalore city varies from $1700 \mathrm{MT} /$ day to $2300 \mathrm{MT} /$ day and the composition of waste is as given in Table 11.

Table 11: Physical characteristics of Bangalore Municipal Solid Waste

\begin{tabular}{ll}
\hline Organic waste (\%) & 60 \\
\hline Dust (\%) & 5 \\
Paper (\%) & 12 \\
Plastic (\%) & 14 \\
Glass (\%) & 4 \\
Metal (\%) & 1 \\
Bio Medical Waste & 1 \\
Card Board & 1 \\
Rubber & 1 \\
Miscellaneous (\%) & 1 \\
\hline
\end{tabular}

Source : BMP

The quantification of the solid waste is essential for designing and monitoring the sanitary landfill sites for the solid waste disposal. However, BMP does not possess weighing facility and thus information is not available for the quantity of waste generated in the past. The composition of waste for the entire city has been found as given in table 11, but the composition of waste ward wise has still not been identified.

\section{Collection}

The most common method of collection in Bangalore city right now is door-to-door collection method followed by the community bin collection method. In 2003, the door-to-door collection method was implemented in 60 health wards. Table 12 gives the details of health wards having door-to-door collection in 2003. 
Table 12: Health Wards Covered under House-to-House Collection in 2003

\begin{tabular}{llll}
\hline $\begin{array}{l}\text { Sr. } \\
\text { No. }\end{array}$ & Zone No. & Health Wards & $\begin{array}{l}\text { No } \\
\text { Wards }\end{array}$ \\
\hline 1. & East Zone & 69a, 70a, 71a, 74c, 75a, 77b, 78c, 80b, 86a, 90b, 91b, 15 \\
& & $92 b, 98 a, 99 b$ & \\
2. & South & 31, 32a, 33a, 34a, 36c, 42b, 43b, 44a, 44b, 45a, 46a, 27 \\
& Zone & 47a, 47b, 48a, 49a, 50a, 50c, 51a, 51b, 52a, 58a, 58c, \\
& & 59a, 60a, 61a, 62a, 62b & \\
3. & West & 4b, 5a, 7b, 8a, 9b, 10, 14a, 15a, 21c, 24a, 25a, 27a, 18 \\
& Zone & 28a, 29b, 30 & \\
Total Wards & &
\end{tabular}

Source: BMP

As per the current record all the wards in the city have door-to-door collection and all the community bins have been removed. However, during site survey it was observed that many of the wards still have community bins that are in a very dilapidated state.

Table 13: Vegetable / Fruit Markets

\begin{tabular}{|c|c|}
\hline Sr. No. & Name of the Market \\
\hline 1. & Yeshwantpur Vegetable Market \\
\hline 2. & Malleshwaram Vegetable and Fruit Market \\
\hline 3. & Shadhadavpuram Vegetable Market \\
\hline 4. & City Market \& Vegetable Market \\
\hline 5. & Kalasi Palyan Mix Market \\
\hline 6. & Basansuda market \\
\hline 7. & Jainagar General Vegetable Market \\
\hline 8. & Madiwala Market \\
\hline 9. & Jhaman Market, Chicken, Poultry, Vegetable etc. \\
\hline 10. & Ulsoor Market, Vegetables \\
\hline 11. & Russel Market \\
\hline 12. & Vinaynagar Market \\
\hline
\end{tabular}


A large quantity of organic waste is generated from the markets. This waste is collected using separate trucks once every morning and evening.

\section{Transfer and Transport}

The waste collected in pushcarts from lanes is transferred to a truck at a meeting point called a synchronization point. The truck arrives at the synchronisation point at a specified time and place. The waste is transported to disposal site by means of a large capacity tipper truck and in few wards by a small capacity tipper truck or dumper placers. The truck is covered with a mesh and a polythene sheet to prevent scattering. Currently Bangalore city has no transfer stations for intermediate storage of waste and intermediate segregation of waste.

Table 14: The Type and number of vehicles in Bangalore Metropolitan Area

\begin{tabular}{ll}
\hline Type of Vehicle & Number of vehicle \\
\hline Compacter Vehicle (large capacity) & 9 \\
Compacter Vehicle (small capacity) & 26 \\
Tipper (large capacity) & 254 \\
Tipper (small capacity) & 24 \\
Dumper placer with one container (3.5 m3 cap.) & 13 \\
\hline
\end{tabular}

\section{Process}

\section{Karnataka Compost Development Authority (KCDC)}

The Karnataka Compost Development Corporation (KCDC) was one of 11 composting units set up in 1975 based on the technology suggested by WHO. Within a year, 10 of these units had to be closed, because the technology suggested by WHO was unable to successfully handle composting of unsegregated Indian waste. Also the usage of raspers (crushing and grinding machines) caused problems selling the compost because the quality was poor due to existence of glass splinters and other non-biodegradable material.

In the 70ies, on 15 acres of land KCDC processed 50-60 tons of mixed waste per day. By 2002 the capacity was expanded to 8.95 hectares, processing 150 tons/day. Currently the units process 
250 tons/day of mixed waste plus 50 tons/day of market waste, which is collected using vehicles owned by KCDC.

Waste heaps (approx. 3.96m wide, 3.05m high and of varying length) are shaped using 3 pay loaders (Front End Loaders). These vehicles are also used for turning the heaps. Cowdung slurry (made by adding 2 baskets of fresh cowdung to 200 litres of water) is used as starter culture, which is sprayed onto the waste heaps.

The microbial degradation process starts on the same day the waste is made into windrows on the compost yard. This degradation occurs as a two staged process. First a high temperature stage (70-75 ${ }^{\circ} \mathrm{C}$ ) lasting for $10-15$ days is performed followed by a middle temperature stage (40-45 $\left.{ }^{\circ} \mathrm{C}\right)$. Waste material only going through a composting process stays in the heaps for about 60 days. For the planned vermicomposting process, partly composted material (after 25-30 days) is taken from the heaps and piled into bins. After leaving the waste for 3-4 days to bring the temperature down to 27-30 degrees, worms are introduced. Four species of African worms are used for this process. This vermicomposting in bins takes about 30-40 days, depending on worm density. A top layer of vermicastings is harvested every 3 days and sieved by a rotary screen.

Aerobic windrows go through 4 sieving stages after 60 days. Mesh size is $50 \mathrm{~mm}, 25 \mathrm{~mm}, 8 \mathrm{~mm}$ and $4 \mathrm{~mm}$, all through rotary screen. The $50 \mathrm{~mm}$ screen removes $80-90 \%$ of the nonbiodegradables, which amount to $30 \%$ by weight. Two Bobcats are used for cleaning the site and feeding the rotary screens and spreading coarse compost for soaking up leachate from the heaps. The compost is then packed and sold and the rejects are emptied into the Adgowdi quarry site, which is $7 \mathrm{~km}$ away from the composting plant. It is observed that waste pickers are active at the plant site for collection of recyclables such as tin, glass, plastic, rubber, etc. The plant authorities have given contract for waste picking and transport rejects to a private contractor.

Plain $4 \mathrm{~mm}$ compost is sold at Rs 950/ton. Enriched compost contains $75 \%$ plain compost $+2.5-$ 3\% Rock phosphate ( Rs 3300/t) + Neem cake ( Rs 3900/ton) + 5-6\% poultry manure (400/ton) + 5-6\% sugar-factory press mud ( 350/ton). It is sold for Rs 1600 per ton locally or Rs 2700 per ton at Bidar in far north Karnataka. The composts are used on farms, estates and plantations, and 
sold through the Dept of Agriculture or Horticulture, with subsidies. These Departments are given 2 months' credit, and dealer margins are $10-15 \%$. Vermicompost is sold at Rs 2.75 per $\mathrm{kg}$ unbagged, or Rs 3.40-3.50 per kg in 50-kg bags. City sales are at Rs 4 per kg, door delivery.

\section{Terra Firma Bio-technologies}

Terra-Firma Bio-Technologies Limited is one of the first private enterprises in India, which produces compost from urban waste by applying a vermicomposting technology on a medium scale (Shah et al., 1997). It was motivated by opportunities caused by liberalization in India, decreasing subsidies for chemical fertilizers and the garbage problem in Bangalore. Commercial

production was started in 1994 after several years of experimentation with the composting process and the cultivation of earthworms.

Terra-Firma is a sister company of Blue Crystal Agro, which has been producing agrochemicals and other fertilizers since 1985. Currently they have 2.03 hecatres of land at the Baneragatta Road. The present input to the plant site is approximately 100TPD. Out of this input lesser than 25 TPD is collected and transported from Bangalore vegetable markets. The rest of the inputs come from agricultural waste. The waste received is stored in storage tanks and is mixed with coir, press mud, EM solution and allowed to decompose for 30 days. Many additives are also used to enrich the waste including poultry waste, cow dung, water hyacinth, algae, micronutrients etc. It is transferred to RCC tanks to which earthworms are added. The waste in the tank is turned regularly and aerated through pipes. The castings are scrapped from the top layer, sieved and packed for sale. The entire process takes about 2 months to complete.

The total Municipal waste generated is estimated to be around 2500 TPD. Out of this quantity, a total of about $400 \mathrm{TPD}$ is sent to three facilities for converting to compost or vermicompost. The rejects from these facilities are disposed off into nearby quarry pits or debris yards. The balance of 2100TPD is not processed and being disposed in either one of the official or unauthorized dump yard around the city. 


\section{Proposal for Waste to Energy Plant}

Srinivas Gayathri Resource Recovery (SGRR) has proposed to set up a plant for Waste to Energy conversion. This plant is to be located adjacent to Mandur landfill site. At present 10.12 hectares of land has been allotted for this project. This project proposes to set up a plant for converting Municipal Solid Waste (MSW) to fuel pellets, as well as fuel that finds use in the industry for heating purposes. This MSW processing plant proposal is based on the technology developed on pilot scale by the Department of Science and Technology, Government of India. The fuel fluff/pellets made of segregated Indian waste has proven to have a calorific value of 3000- $3500 \mathrm{Kcal} / \mathrm{kg}$ with a moisture content of $10 \%$ at the final stage. It is proposed that excess fuel being produced at SGRR Pvt. Ltd will be sold to industries having Coal fired boilers as well as biomass based power plants.

However, no plan has yet been proposed for the selection of wards from where the waste is to be collected and the strategy to be adopted for segregated waste collection.

\section{Disposal}

\section{Betahalli (Mavallipuram) dump yard}

The Betahalli dump yard is situated $18 \mathrm{~km}$ North West of Bangalore city. This is a private property of 4.86 hectares out of which 3.24 hecatres is being used for dumping of MSW. The remaining acreage has banana plantations. This property has eucalyptus plantations surrounding it on two sides. There are few localities that are coming up in the vicinity of the dump yard at about $2 \mathrm{~km}$ distance. There is a water body at a distance of $3 \mathrm{~km}$ and an Air force airbase at a distance of $8.5 \mathrm{~km}$.

The waste is brought in by the municipal and contract lorries. This waste is dumped in the yard in a form a heap. There are three JCB's (Front End Loaders) in the dump yard for the leveling of waste once it is dumped. As per the instructions given by BMP, the waste should be sprayed with EM (Effective Micro organisms) solution, covered with a $10 \mathrm{~cm}$ layer of debris and sprayed with water once it is leveled. The solution used for spraying is prepared by mixing 4 lts of EM solution with $8 \mathrm{~kg}$ of molasses or Jaggery and 150 lts of water. After mixing it is allowed to stay 
for 7-8 days after which the $\mathrm{pH}$ reduces to 3.4. Once the $\mathrm{pH}$ reaches 3.4 the solution is said to be ready for use. The EM stock solution composition is as follows:

Lactic Acid Bacteria

Actinomycetes

Photosynthetic bacteria

Yeast

Bacteria

Lactobacillus sp.

Streptococcus sp.

Streptomyces sp.

Rhodopseudomonas sp.

Saccharomyces $\mathrm{sp}$.

Propionibacterium sp.

This solution speeds up the degradation process of the MSW and reduces the volume, flies and odour.

The observations made on the site are:

- A large number of rag pickers collect recyclable waste from the landfill and pay a small amount to have access to the waste.

- There is a recycling dealer in the dump yard itself who buys the recyclable material from the rag pickers and there is one dealer on the way to the dump yard that buys the recyclable waste from the lorry driver.

- The leveling of MSW after dumping is not carried out efficiently due to less number of front end loaders

- The foul odour was strong and could be got at long distances.

- Large number of flies, birds and stray dogs.

- There is emission of methane gas from the dump yard, due to which the waste can be easily set on fire.

- There is always a queue of at least 5-10 Lorries waiting to unload; this is due to the lack of number of front-end loaders to level the MSW.

- This dump yard has no fencing, weigh bridge and no proper approach roads. 


\section{Proposed Sanitary landfill Sites}

There are currently four composting plants cum sanitary landfill sites cum proposed, they are Mavallipura- Bangalore North Taluk

Mandur- Bangalore East Taluk

Kananhalli- Bangalore North Taluk

\section{Mavallipura Site Features}

The proposed site situated at Mavallipura village, Hesargatta Zone, Bangalore North, Bangalore, Karnataka shall be used for the processing of municipal solid waste generated from Bangalore city. The features of the site are given below:

Table 15: Mavallipura Site Features

\begin{tabular}{|c|c|}
\hline Features & Details \\
\hline Latitude and Longitude & $\begin{array}{l}\text { Latitude } 13^{\circ} 50 \text { ’m North } \\
\text { Longitude } 77^{\circ} 36^{\prime} \text { East }\end{array}$ \\
\hline Mean elevation of the site & Ranging from $51.38 \mathrm{~m}$ to $38.65 \mathrm{~m}$ above MSL \\
\hline Land area & 40.49 hecatres \\
\hline Land use & Barren \\
\hline Nearest highway & $\begin{array}{l}7.5 \mathrm{~km} \text { away from the National highway No. } 7 \text { connecting } \\
\text { Mangalore to Chennai }\end{array}$ \\
\hline Access Road & Approach road to the site is well developed \\
\hline Water bodies and dams & Hessargatta water tank - $5.5 \mathrm{~km}$ \\
\hline $\begin{array}{l}\text { Reserve forests, Ecological zones, } \\
\text { Monuments, railway station, } \\
\text { major settlement }\end{array}$ & None within $10 \mathrm{~km}$ \\
\hline Socioeconomic & Agriculture based \\
\hline Minor settlement & Mahvallipura village with $3 \mathrm{~km}$ \\
\hline Airport & $\begin{array}{l}\text { Bangalore airport more than } 30 \quad \mathrm{~km} \\
\text { Deccan aviation center at } 8 \mathrm{~km}\end{array}$ \\
\hline
\end{tabular}




\section{Mandur Site Features}

The Mandur village is located in the Bangalore south taluka of Bangalore Urban District

Table 16: Mandur Site features

\begin{tabular}{ll}
\hline Features & Details \\
\hline Latitude and Longitude & Latitude $13^{\circ} 05^{\prime \prime} 01^{\prime}$ North Longitude $77^{\circ} 43^{\prime \prime} 45^{\prime}$ East \\
Land area & 66.80 hectares \\
Land use & Barren \\
Access Road & Approach road to the site is well developed \\
Water bodies and dams & Hoskote Lake- within 5 km radius \\
& Medahalli lake- within 5 km radius \\
& Irrigation bore well-adjacent to lake \\
& Drinking water bore well-Marasandra village \\
Reserve forests, Ecological & None within 10 km \\
zones, Monuments, railway & \\
station, major settlement & Drinking water bore well-Gundur village \\
Socioeconomic & Agriculture based \\
Minor settlement & Mandur village within 3 km \\
Airport & Bithin 3 km \\
\hline
\end{tabular}

This site is suitable for a sanitary landfilling. However, since the vicinity to the village and drinking water supply is close. The landfilling should be carried out with strict monitoring.

\section{Kannahalli Site}

Kannahalli site is located near Magadi Road at approximately 20km from Bangalore. The land currently available is 11.60 hectares. BMP would endeavor to make available a total of 28.34 hectares for the project. The soil cover is suitable for landfill cover with permeability coefficient of $1.76 * 10^{-6} \mathrm{~cm} / \mathrm{sec}$. There is a level difference of approximately $17 \mathrm{~m}$ in the middle of the site. Ground water is available at $76-107 \mathrm{~m}$. Karnataka Pollution Control Board has 
authorized this site, but due to public agitation against the setting up sanitary landfill, this project has been stalled.

\subsection{The Stakeholders and their responsibilities}

Ministry of Environment and Forests is responsible for all of the environmental policy at the national level, including the management of waste. The Ministry has an overview of all the activities of the MSWM sector and makes sure that it is performed well.

Central Pollution Control Board keeps a check on all the activities that have potential to pollute the environment, which includes the monitoring of the municipal solid waste management in the country. It has divisions in each state that report to СPCB on the environmentally hazardous activities in the state, the actions taken towards them and the improvements made by the industries and public towards a cleaner environment.

Karnataka Pollution Control Board keeps a check on all the activities that have potential to pollute the environment, which includes the monitoring of the municipal solid waste management in the state. It reviews the Environmental Impact Assessment carried out by the agencies prior to the construction of a landfill site, installation of an incinerator or any other processing plant. It carries out public participation meeting to make the public aware of the proposed project and its benefits. Public participation is especially important so that once the project is started there should not be any agitation against the project.

Bangalore Mahanagara Palike is responsible for the making of the solid waste management policy, setting up the targets and objectives. They are responsible for managing the solid waste in the city and are answerable to the State Board and Karnataka pollution control Board. They also have the authority to privatize the solid waste management sector.

\section{Organizational Structure of Health Department}

The MSWM is the responsibility of the Bangalore Mahangara Palike, where the health department has been mainly in charge of all the activities. The hierarchy of the Health 
Department in charge of SWM is a pyramidal structure headed by Chief Health Officer. For effective administration, the city has been divided three zones namely east, west and south. A Zonal Health Officer administers each zone. There are two Deputy Health Officers to assist him. Each zone consists of 10 ranges headed by a Medical Officer of Health. Each Medical Officer of Health is assisted by Senior, Junior Health Inspectors and Sanitary Daffedars. The field worker who is employed in the sanitation work is known as pourakarmika.

\section{NGOs / CBOs}

Swabhimana, Waste wise, Swachha Bangalore, Shuchi Mitras etc are few of the NGOs/CBOs that support the MSWM in the city. Their functions are stated below:

- They carry out public grievance meeting to identify the problem spots and convey these complaints to the authorities

- They collaborate with authorities to carry out the door-to-door collection of segregated waste

- They identify public volunteers to monitor the solid waste management in their respective areas.

- Few NGOs have also set up decentralized composting plants in residential areas and for this they also carry out door-to-door collection and educate public to segregate the waste prior to disposal.

- They carry out public meetings in schools, colleges, public places etc to educate the public about segregation of waste, non-littering, etc

\section{Private formal sector}

Currently out of the 294 health wards in Bangalore city, 182 wards have been given out on a private contract. This includes the functions of collection of waste, transfer of waste to trucks, transport of waste to the specified dump yard. The dump yards that are currently being used are all owned by private entities They have the responsibility of disposing of the waste by alternative layering of waste and soil, spraying it with EM solution and water.

Karnataka Pollution Control Board (KCDC) is a government-aided organization. This carries out the function of composting (windrow and vermicomposting). 
Terra Firma Biotechnologies is a private organization that carries out vermicomposting Ramky Consultants is a private consultancy proposing to set up a sanitary landfill site in Bangalore.

Srinivas Gayathri Resource Recovery is a private consultancy proposing to set up a waste to energy plant and a sanitary landfill site in Bangalore.

\section{Private informal sector}

The informal sector in the city is very large and plays a very vital role in the MSWM. It comprises of the rag pickers who retrieve recyclable waste from the community bins and landfills, the people who buy recyclable waste from households usually called as 'batli wallas', the middlemen who buy waste from the rag pickers and 'batli wallas' and sell it to either bigger dealers or to recycling factories. Municipal workers like the pourakarmika collects waste from the households and retrieve the recyclable waste, even the lorry workers retrieve the recyclable waste before transferring the waste into the lorry. The waste retrieved by them is sold to the informal sector.

\section{Donor agencies}

DCN (Development corporation of Norway), GTZ (Deutsch Gesellschaft fur Technische Zusammenarbeit) and WHO (World Health Organization) are few of the international organizations that have sponsored projects in Bangalore. WHO has sponsored large scale composting plants all over India and DCN has sponsored decentralized plants all over Bangalore.

Service users comprise of the entire public in the city and also include the tourists visiting the city. 
Table 17: Existing partnerships for managing solid wastes

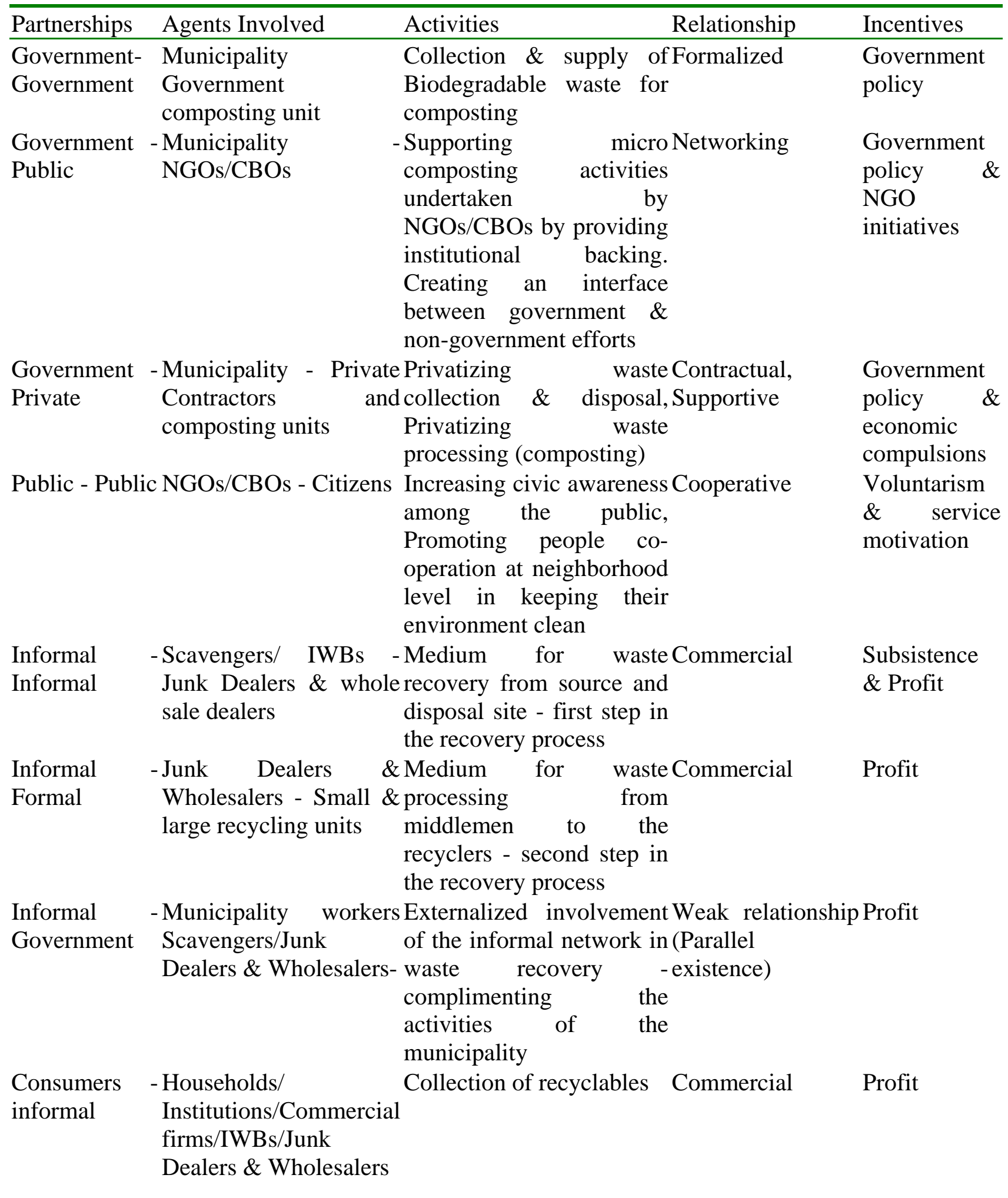

Modified from (Beukering, et al 1999) 


\section{RESULTS AND DISCUSSION}

From the audit carried out ward wise, the techniques adopted in each ward and the shortcomings of the techniques adopted have been identified. In Table 18, 19, 20, 21, 22, 23 and 24 the techniques used, the shortcomings and the measures to be taken to fulfill these shortcomings have been given has been given ward wise.

Table 18: MSWM in Shivaji Nagar (Ward 79)

\begin{tabular}{|c|c|c|}
\hline Function & Short coming & Suggestion \\
\hline \multicolumn{3}{|l|}{ Storage } \\
\hline \multirow{2}{*}{$\begin{array}{l}\text { About }(5-8) \quad \text { Open } \\
\text { circular cement bins }-0.9 \\
\text { m diameter and } 0.6 \mathrm{~m} 3 \\
\text { storage capacity, in } \\
\text { residential areas }\end{array}$} & Few of the cement bins are broken & $\begin{array}{l}\text { Regular repair and replacement of } \\
\text { the bins }\end{array}$ \\
\hline & $\begin{array}{l}\text { The cement and metal bins are } \\
\text { open to the atmosphere }\end{array}$ & Bins kept covered \\
\hline \multirow{2}{*}{$\begin{array}{l}\text { large Metal Bins - 1.5m } \\
\text { wide and 1m high, in } \\
\text { commercial areas }\end{array}$} & $\begin{array}{l}\text { Metal bins are broken, rusted and } \\
\text { have sharp edges }\end{array}$ & Removal of rusted bins \\
\hline & $\begin{array}{l}\text { No provision for separate storage } \\
\text { of segregated waste }\end{array}$ & $\begin{array}{l}\text { Partitioned bins or separate bins } \\
\text { for different types of waste }\end{array}$ \\
\hline \multicolumn{3}{|l|}{ Collection } \\
\hline \multirow{2}{*}{$\begin{array}{l}\text { Door to Door method - } \\
\text { Adopted in the whole } \\
\text { ward, for residential and } \\
\text { commercial areas }\end{array}$} & $\begin{array}{l}\text { Not all drums are painted as per } \\
\text { the regulations of green for } \\
\text { biodegradable, white for } \\
\text { recyclable and black for mixed }\end{array}$ & $\begin{array}{l}\text { Painting of drums at regular } \\
\text { intervals to make it more } \\
\text { convenient to workers }\end{array}$ \\
\hline & \begin{tabular}{|l} 
Segregation not carried out by \\
worker nor householder, though \\
separate bins are provided
\end{tabular} & $\begin{array}{l}\text { Workers accept only segregated } \\
\text { waste from households }\end{array}$ \\
\hline $\begin{array}{l}\text { The recyclable waste is } \\
\text { retrieved by the worker } \\
\text { and it is sold to the } \\
\text { informal sector }\end{array}$ & $\begin{array}{l}\text { PET bottles and thin plastic bags } \\
\text { are not retrieved. The soiled } \\
\text { recyclable material cannot be } \\
\text { retrieved. }\end{array}$ & \\
\hline $\begin{array}{l}\text { Community bin method - } \\
\text { adopted partially in } \\
\text { commercial area }\end{array}$ & Waste is stored in the mixed state & $\begin{array}{l}\text { Provision of separate bins with } \\
\text { labels or bins with partition }\end{array}$ \\
\hline
\end{tabular}




\begin{tabular}{|c|c|c|}
\hline $\begin{array}{l}\text { Recyclable material is } \\
\text { retrieved by rag pickers } \\
\text { from bins }\end{array}$ & $\begin{array}{l}\text { PET bottles and thin plastic bags } \\
\text { are not retrieved. The soiled } \\
\text { recyclable material cannot be } \\
\text { retrieved. }\end{array}$ & \\
\hline \multirow[t]{2}{*}{ Sweeping } & $\begin{array}{l}\text { The dirt is pushed into the drains } \\
\text { which blocks the drains }\end{array}$ & $\begin{array}{l}\text { Workers educated on effect of } \\
\text { blocked drains and regular } \\
\text { inspection of drains }\end{array}$ \\
\hline & $\begin{array}{l}\text { Workers do not use the gloves and } \\
\text { footwear that are provided for } \\
\text { protection }\end{array}$ & $\begin{array}{l}\text { Mandatory usage of the protection } \\
\text { gear provided }\end{array}$ \\
\hline \multicolumn{3}{|c|}{\begin{tabular}{|l|l|} 
Transfer and Transport \\
\end{tabular}} \\
\hline \multicolumn{2}{|c|}{$\begin{array}{l}\text { Waste is collected in The waste even if segregated by } \\
\text { pushcarts from narrowthe workers and stored in separate } \\
\text { lanes and meets at adrums, the waste gets mixed } \\
\text { synchronization point at during transfer from pushcarts to } \\
\text { a specified time. Thellorry. This is because there is no } \\
\text { waste is transferred from facility in the lorry for separate } \\
\text { the pushcart to the truck. storage of waste }\end{array}$} & $\begin{array}{l}\text { A small capacity truck and a large } \\
\text { capacity truck can be assigned for } \\
\text { the collection of dry and wet waste } \\
\text { respectively. A better option is to } \\
\text { have a partition in a single truck } \\
\text { for the collection of segregated } \\
\text { waste. }\end{array}$ \\
\hline $\begin{array}{l}\text { The lorry worker } \\
\text { retrieves recyclable } \\
\text { material during transfer } \\
\text { of waste from push cart } \\
\text { to lorry }\end{array}$ & $\begin{array}{l}\text { PET bottles and thin plastic bags } \\
\text { are not retrieved. The soiled } \\
\text { recyclable material cannot be } \\
\text { retrieved. }\end{array}$ & $\begin{array}{l}\text { Only segregated waste should be } \\
\text { accepted to be filled into the lorry }\end{array}$ \\
\hline \multirow[t]{2}{*}{$\begin{array}{l}\text { The truck also stops near } \\
\text { every community bin and } \\
\text { the waste is transferred } \\
\text { from the bin to the truck }\end{array}$} & Manual transfer of waste & $\begin{array}{l}\text { Mechanical loading collection } \\
\text { vehicles or proper equipment for } \\
\text { transfer of waste }\end{array}$ \\
\hline & $\begin{array}{l}\text { During transfer of waste from bins } \\
\text { to trucks, there is a small amount } \\
\text { of spillage and the waste is not } \\
\text { completely cleared out }\end{array}$ & $\begin{array}{l}\text { Mechanically loading collectior } \\
\text { vehicles or trained personnel }\end{array}$ \\
\hline \multirow[t]{3}{*}{$\begin{array}{l}\text { BMP truck - } 4 \text { large } \\
\text { Capacity tipper truck }\end{array}$} & $\begin{array}{l}\text { Mesh covering - } 4 \text { trucks, Partial } \\
\text { Polythene covering }-3 \text { trucks, } \\
\text { Complete polythene covering- } 1 \\
\text { truck }\end{array}$ & $\begin{array}{l}\text { Trucks completely covered with } \\
\text { polythene to prevent scattering o } \\
\text { waste and foul odour }\end{array}$ \\
\hline & $\begin{array}{l}\text { Leakage of wet waste from truck } \\
\text { during transportation }\end{array}$ & Provision of proper enclosure \\
\hline & $\begin{array}{l}\text { Foul odour emitted from the waste } \\
\text { during transportation }\end{array}$ & Regular inspections \\
\hline
\end{tabular}




\begin{tabular}{|c|c|c|}
\hline & $\begin{array}{l}\text { The waste is not segregated at an } \\
\text { intermediate level and is directly } \\
\text { transported to the disposal site }\end{array}$ & $\begin{array}{l}\text { Transfer stations need to be } \\
\text { introduced in cities where waste } \\
\text { can be further segregated and }\end{array}$ \\
\hline & $\begin{array}{l}\text { Long distance from ward to dump } \\
\text { site, hence only one trip a day is } \\
\text { made by each truck }\end{array}$ & $\begin{array}{l}\text { higher efficiency for transportation } \\
\text { can achieved by increasing the } \\
\text { number of trips made by each truck }\end{array}$ \\
\hline Process & $\begin{array}{l}\text { No processing carried out prior to } \\
\text { disposal }\end{array}$ & Anaerobic digestion \\
\hline & & $\begin{array}{l}\text { Ward } 79 \text { has a market that sells } \\
\text { meat, vegetables and fruit. This } \\
\text { can be directly sent to an anaerobic } \\
\text { digester or an anaerobic digester } \\
\text { can be installed close by. }\end{array}$ \\
\hline & & Composting \\
\hline & & $\begin{array}{l}\text { The organic waste collected from } \\
\text { the other parts of the ward can be } \\
\text { transported to a compost plant }\end{array}$ \\
\hline & & $\begin{array}{l}\text { The recyclable material should be } \\
\text { retrieved for recycling or reuse }\end{array}$ \\
\hline Disposal & & \\
\hline Dump yard in Betahalli & Foul odour, flies and bird menace & $\begin{array}{l}\text { Usage of higher quantity of EM } \\
\text { solution }\end{array}$ \\
\hline & Stray dog nuisance & \\
\hline & $\begin{array}{l}\text { Waste burnt emitting toxic fumes } \\
\text { and causing air pollution }\end{array}$ & $\begin{array}{l}\text { Waste burning should be } \\
\text { prohibited and strict action should } \\
\text { be taken if still continued }\end{array}$ \\
\hline & $\begin{array}{l}\text { Waste is dumped in heaps causing } \\
\text { scattering }\end{array}$ & $\begin{array}{l}\text { Usage of front end loaders for } \\
\text { leveling and use soil cover }\end{array}$ \\
\hline & Soil contamination & \\
\hline & $\begin{array}{l}\text { The lorry workers and drivers are } \\
\text { exposed to diseases }\end{array}$ & Provision of masks and safety gear \\
\hline $\begin{array}{l}\text { Rag pickers retrieve the } \\
\text { recyclable material from } \\
\text { the landfill }\end{array}$ & High exposure to diseases & Provision of masks and safety gear \\
\hline & & $\begin{array}{l}\text { Closure of dumpsite and replace } \\
\text { with sanitary landfill }\end{array}$ \\
\hline
\end{tabular}




\begin{tabular}{|c|c|c|}
\hline $\begin{array}{l}\text { Shivajinagar ward } \\
\text { Population }-34988 \\
\text { Area- } 1.33561 \mathrm{sq} \mathrm{km} \\
\end{array}$ & & \\
\hline Functional element & Implement and workforce & \\
\hline Storage & $\begin{array}{l}\text { Bins } \\
\text { Cement bins- } 0.9 \text { m diameter } \\
\text { and } 0.6 \mathrm{~m} 3-9 \text { in number } \\
\text { Metal bins- } 1.5 \mathrm{~m} \text { wide and } 1 \mathrm{~m} \\
\text { high- } 4 \text { in number }\end{array}$ & $\begin{array}{l}70 \% \text { of the bins used are } \\
\text { cement bins } \\
30 \% \text { are metal bins } \\
30 \% \text { of bins have cover }\end{array}$ \\
\hline Collection & $\begin{array}{l}\text { Community bin } \\
\text { Once in a day } \\
\text { Door to door } \\
\text { Once in a day }\end{array}$ & $\begin{array}{l}40 \% \text { of the commercial areas } \\
10 \% \text { of the residential areas } \\
90 \% \text { of the commercial areas } \\
100 \% \text { of the residential areas } \\
30 \% \text { of the commercial areas } \\
\text { have community bins and door } \\
\text { to collection } \\
10 \% \text { of the residential areas } \\
\text { have door to door and } \\
\text { community bin }\end{array}$ \\
\hline & $\begin{array}{l}\text { Pourakarmikas-192 } \\
\text { Pushcarts-126 }\end{array}$ & $\begin{array}{l}\text { Sufficient number of } \\
\text { pourakarmikas } \\
\text { Sufficient number of pushcarts }\end{array}$ \\
\hline Transfer and transport & $\begin{array}{l}\text { No transfer station } \\
\text { Trucks -4 } \\
\text { Mesh covering - } 4 \text { trucks } \\
\text { Polythene covering - } 3 \text { trucks }\end{array}$ & $\begin{array}{l}\text { Waste transported directly to } \\
\text { disposal site } \\
100 \% \text { of the trucks have mesh } \\
\text { cover } \\
75 \% \text { have polythene cover }\end{array}$ \\
\hline Process & Recycling by informal sector & \\
\hline Disposal & Dump yard & Open dump \\
\hline
\end{tabular}

The community bin storage that has been provided in Shivajinagar is of two types metal bin and cement bin. Only the metal bins are provided with cover i.e. only $30 \%$ of the bins have cover. The remaining uncovered bins lead to foul odour, flies and unaesthetic appearance. The community bin storage has been provided only to $40 \%$ of the commercial area resulting in disposal of waste on roadsides due to high rate of waste generation in these areas. The door-todoor collection is carried out in residential and commercial areas. In residential areas there are few dilapidated bins that have unaesthetic appearance, and are not used efficiently. $75 \%$ of the 
trucks used have partial polythene covering that has lead to scattering of waste and foul odour during transportation.

Recycling is carried out by the informal sector this has lead to a high efficiency in recovery of waste, but PET and thin plastic bags are not recovered. The final disposal is carried out in open dump yard resulting in scattering, foul odour, leachate formation and air pollution. 
Table 19: MSWM in Malleswaram (Ward 7)

\begin{tabular}{|c|c|c|}
\hline Function & Short coming & Suggestion \\
\hline \multicolumn{3}{|l|}{ Storage } \\
\hline \multicolumn{3}{|l|}{$\begin{array}{l}\text { The waste is stored in } \\
\text { households and in shops } \\
\text { until it is collected by the } \\
\text { door to door collector }\end{array}$} \\
\hline \multicolumn{3}{|l|}{ Collection } \\
\hline \multirow[t]{2}{*}{$\begin{array}{l}\text { Door to Door method - } \\
\text { Adopted in the whole } \\
\text { ward, for residential and } \\
\text { commercial areas }\end{array}$} & $\begin{array}{l}70 \% \text { of drums are not painted as } \\
\text { per the regulations of green for } \\
\text { biodegradable, white for } \\
\text { recyclable and black for mixed }\end{array}$ & $\begin{array}{l}\text { Painting of drums at regular } \\
\text { antervals to make it more } \\
\text { convenient to workers }\end{array}$ \\
\hline & $\begin{array}{l}\text { Segregation not carried out by } \\
\text { worker nor householder, though } \\
\text { separate bins are provided }\end{array}$ & $\begin{array}{l}\text { Workers accept only segregated } \\
\text { waste from households }\end{array}$ \\
\hline \multirow[t]{3}{*}{$\begin{array}{l}\text { The recyclable waste is } \\
\text { retrieved by the worker } \\
\text { and sells it separately to } \\
\text { the informal sector }\end{array}$} & $\begin{array}{l}\text { PET bottles and thin plastic bags } \\
\text { are not retrieved. } \\
\text { recyclable material } \\
\text { retrieved. }\end{array}$ & \\
\hline & \begin{tabular}{|lc} 
Waste heaps found near \\
commercial areas
\end{tabular} & $\begin{array}{l}\text { Placement of large community bins } \\
\text { in commercial areas (in } \\
\text { commercial area there is a } \\
\text { possibility of sudden generation of } \\
\text { a large quantity of waste that } \\
\text { cannot be stored in the shop till the } \\
\text { next day) }\end{array}$ \\
\hline & & $\begin{array}{l}\text { Small litter bins should be } \\
\text { provided for the pedestrians in } \\
\text { commercial areas and bus stands }\end{array}$ \\
\hline \multirow[t]{2}{*}{ Sweeping } & $\begin{array}{l}\text { The dirt is pushed into the drains } \\
\text { which blocks the drains }\end{array}$ & $\begin{array}{l}\text { The workers educated on the } \\
\text { affects of blocked drains and } \\
\text { regular inspection of drains }\end{array}$ \\
\hline & $\begin{array}{l}\text { Workers do not use the gloves and } \\
\text { footwear that are provided for } \\
\text { protection }\end{array}$ & $\begin{array}{l}\text { Mandatory usage of the protection } \\
\text { gear provided }\end{array}$ \\
\hline Transfer and Transport & & \\
\hline
\end{tabular}


The waste collected in The waste even if segregated by|A small capacity truck and a large pushcarts from narrowthe workers and stored in separate capacity truck can be assigned for lanes and meet at adrums, the waste gets mixedthe collection of dry and wet waste synchronization point atduring transfer from pushcarts torespectively. A better option is to a specified time. Thelorry. This is because there is nothave a partition in a single truck waste is transferred fromfacility in the lorry for separatefor the collection of segregated the pushcart to the truck. storage of waste waste.

The lorry worker|PET bottles and thin plastic bags Only segregated waste should be retrieves recyclableare not retrieved. The soiled accepted to be filled into the lorry material during transferrecyclable material cannot be of waste from push cart retrieved. to lorry BMP truck - 3 Large Mesh covering - 5 trucks, No Trucks completely covered with \begin{tabular}{l|l} 
capacity tipper & Polythene covering - 1, Partial polythene to prevent scattering of
\end{tabular} Polythene covering - 2 trucks, waste and foul odour Complete polythene covering - 2 trucks

Contract truck - 1 large There is leakage of wet waste from Provision of proper enclosure capacity tipper truck during transportation

Trip truck - 1 large Foul odour emitted from the waste Regular inspections \begin{tabular}{ll|}
\hline capacity tipper & during transportation \\
\hline
\end{tabular}

The waste is not segregated at an Transfer stations to be provided intermediate level and is directly|where waste can be further transported to the disposal site segregated and higher efficiency Long distance from ward to dump for transportation can achieved by site, hence only one trip a day is made by each truck ncreasing the number of trips made by each truck

Manual transfer of waste

Mechanical loading collection vehicles or proper equipment for transfer of waste

\begin{tabular}{|l|l|l|}
\hline Process & $\begin{array}{l}\text { No processing carried out prior to } \\
\text { disposal }\end{array}$ & $\begin{array}{l}\text { Recycling of the recyclable } \\
\text { material retrieved from waste }\end{array}$ \\
\hline & & Composting \\
\hline & & $\begin{array}{l}\text { High quantity of yard waste } \\
\text { generated in the ward and also high } \\
\text { quantity of organic waste } \\
\text { generated from the market and } \\
\text { households }\end{array}$ \\
\hline Disposal & & $\begin{array}{l}\text { Usage of higher quantity of EM } \\
\text { solution }\end{array}$ \\
\hline Dump yard in Betahalli & Foul odour, flies and bird menace \\
\hline & Stray dog nuisance & \\
\hline
\end{tabular}




\begin{tabular}{|c|c|c|}
\hline & $\begin{array}{l}\text { Waste burnt emitting toxic fumes } \\
\text { and causing air pollution }\end{array}$ & $\begin{array}{l}\text { Waste burning should be } \\
\text { prohibited and strict action should } \\
\text { be taken if still continued }\end{array}$ \\
\hline & $\begin{array}{l}\text { Waste is dumped in heaps causing } \\
\text { scattering }\end{array}$ & $\begin{array}{l}\text { Usage of front end loaders for } \\
\text { leveling and use soil cover }\end{array}$ \\
\hline & Soil contamination & \\
\hline & $\begin{array}{l}\text { The lorry workers and drivers are } \\
\text { exposed to diseases }\end{array}$ & Provision of masks and safety gear \\
\hline \multirow[t]{2}{*}{$\begin{array}{l}\text { Rag pickers retrieve the } \\
\text { recyclable material from } \\
\text { the landfill }\end{array}$} & High exposure to diseases & Provision of masks and safety gear \\
\hline & & $\begin{array}{l}\text { Closure of dumpsite and replace } \\
\text { with sanitary landfill }\end{array}$ \\
\hline
\end{tabular}

\begin{tabular}{|c|c|c|}
\hline $\begin{array}{l}\text { Malleswaram } \\
\text { Population- } 37760 \\
\text { Area- } 1.69263 \mathrm{sq} \mathrm{km}\end{array}$ & & \\
\hline Storage & $\begin{array}{l}\text { No community bins } \\
\text { Door to door }\end{array}$ & $100 \%$ storage in push carts \\
\hline Collection & $\begin{array}{l}\text { Community Bin method } \\
\text { Door to door collection } \\
\text { Once in a day }\end{array}$ & $\begin{array}{l}\text { Entire area covered by door to } \\
\text { door method of collection }\end{array}$ \\
\hline Transfer and Transport & $\begin{array}{l}\text { No transfer station } \\
\text { Truck with mesh- } 5 \\
\text { Truck with partial polythene } \\
\text { cover- } 2 \\
\text { Truck with Complete } \\
\text { polythene covering - } 2\end{array}$ & $\begin{array}{l}\text { Direct transportation of waste } \\
\text { to disposal site } \\
100 \% \text { of the trucks have mesh } \\
40 \% \text { have partial polythene } \\
\text { cover } \\
40 \% \text { have complete polythene } \\
\text { cover } \\
20 \% \text { have no polythene cover }\end{array}$ \\
\hline Process & Recycling by informal sector & \\
\hline Disposal & Dump yard & Open dump \\
\hline
\end{tabular}

Door to door collection is adopted in the entire area, which has resulted in efficient collection of waste, reduction of littering, foul odour and unaesthetic appearance of bins. However, in commercial areas due to the absence of community bins, sudden waste generated in odd hours, is disposed in the street. Few waste heaps can be found on the roadsides in commercial areas. All the trucks that are used for transportation of waste have meshes that prevent littering of waste, but $40 \%$ of the trucks have partial polythene cover and $20 \%$ have no polythene cover that 
results in scattering of waste and foul odour during transport. The recycling process is carried out by the informal sector that has resulted in high efficiency of recovery of recyclable material. There is no other process carried out leading to the entire waste being disposed. There is a large quantity of organic waste that is produced in this ward, including organic waste generated in a market. The waste is disposed in the Betahalli dump yard, causing foul odour, scattering, leachate formation, and air pollution from burning and methane emission from decomposing organic matter. 
Table 20: MSWM in Koramangala (Ward 67)

\begin{tabular}{|c|c|c|}
\hline Function & Short coming & Suggestion \\
\hline \multicolumn{3}{|l|}{ Storage } \\
\hline \multicolumn{3}{|l|}{$\begin{array}{l}\text { The waste is stored in the } \\
\text { households and in the } \\
\text { shops until it is collected } \\
\text { by the door to door } \\
\text { collector }\end{array}$} \\
\hline \multicolumn{3}{|l|}{ Collection } \\
\hline \multirow[t]{2}{*}{$\begin{array}{l}\text { Door to Door method - } \\
\text { Adopted in the whole } \\
\text { ward, for residential and } \\
\text { commercial areas }\end{array}$} & $\begin{array}{l}20 \% \text { of drums are not painted as } \\
\text { eper the regulations of green for } \\
\text { dbiodegradable, white for } \\
\text { recyclable and black for mixed }\end{array}$ & $\begin{array}{l}\text { Painting of drums at regular } \\
\text { intervals to make it more } \\
\text { convenient to workers }\end{array}$ \\
\hline & $\begin{array}{l}\text { The householders segregate about } \\
20 \% \text { of the waste. The workers } \\
\text { segregate the waste to a certain } \\
\text { level. }\end{array}$ & $\begin{array}{l}\text { Workers accept only segregated } \\
\text { waste from households }\end{array}$ \\
\hline $\begin{array}{l}\text { The recyclable waste is } \\
\text { retrieved by the worker. } \\
\text { and sells it separately to } \\
\text { the informal sector }\end{array}$ & $\begin{array}{l}\text { PET bottles and thin plastic bags } \\
\text { rare not retrieved. The soiled. } \\
\text { precyclable material cannot be } \\
\text { retrieved. }\end{array}$ & $\begin{array}{l}\text { Litter bins in commercial areas and } \\
\text { bus stands for pedestrians to use }\end{array}$ \\
\hline \multirow[t]{2}{*}{ Sweeping } & $\begin{array}{l}\text { The dirt is pushed into the drains } \\
\text { which blocks the drains }\end{array}$ & $\begin{array}{l}\text { Workers educated on effect of } \\
\text { blocked drains and regular } \\
\text { inspection of drains }\end{array}$ \\
\hline & $\begin{array}{l}\text { Workers do not use the gloves } \\
\text { and footwear that are provided for } \\
\text { protection }\end{array}$ & $\begin{array}{l}\text { Mandatory usage of the protection } \\
\text { gear provided }\end{array}$ \\
\hline \multicolumn{3}{|l|}{ Transfer and Transport } \\
\hline $\begin{array}{l}\text { The waste collected in } \\
\text { pushcarts from narrowt } \\
\text { lanes and meet at a } \\
\text { synchronization point at a } \\
\text { specified time. The waste } \\
\text { is transferred from the } \\
\text { pushcart to the truck. }\end{array}$ & $\begin{array}{l}\text { The waste even if segregated by } \\
\text { the workers and stored in separate } \\
\text { adrums, the waste gets mixed } \\
\text { a during transfer from pushcarts to } \\
\text { elorry. This is because there is no } \\
\text { efacility in the lorry for separate } \\
\text { storage of waste }\end{array}$ & $\begin{array}{l}\text { A small capacity truck and a large } \\
\text { capacity truck can be assigned for } \\
\text { the collection of dry and wet waste } \\
\text { respectively. A better option is to } \\
\text { have a partition in a single truck } \\
\text { for the collection of segregated } \\
\text { waste. }\end{array}$ \\
\hline
\end{tabular}


The lorry worker retrieves PET bottles and thin plastic bags Only segregated waste should be recyclable material during are not retrieved. The soiled accepted to be filled into the lorry transfer of waste from recyclable material cannot be push cart to lorry retrieved.

BMP truck - 2 Large Mesh covering - 4 trucks, No Trucks completely covered with \begin{tabular}{l|l} 
capacity tipper & Polythene covering - 1, Completepolythene to prevent scattering of
\end{tabular} polythene covering - 3 trucks waste and foul odour

Contract truck - 1 large There is leakage of wet waste Provision of proper enclosure capacity tipper $\quad$ from truck during transportation

Trip truck - 1 small Foul odour emitted from the Regular inspections capacity compacter

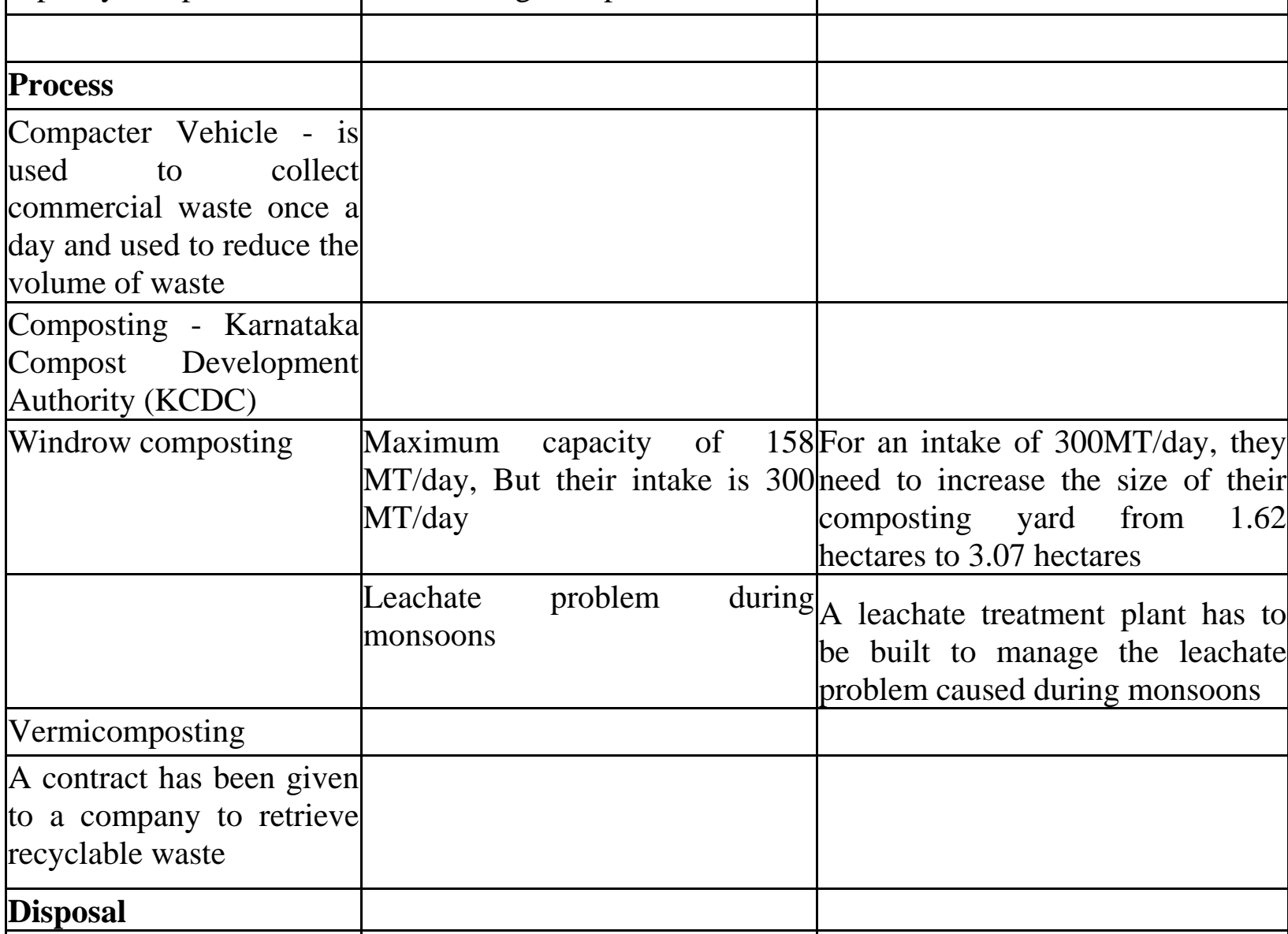

The rejects from KCDC is The waste is dumped more The waste pushed into the quarry sent to a quarry site $2 \mathrm{~km}$ outside the quarry than inside away.

This quarry also receives Quarry is too close to human Immediate closure of quarry waste from other wards habitation that come directly without processing 


\begin{tabular}{|l|l|l|}
\hline & $\begin{array}{l}\text { The waste is burnt and toxic gases } \\
\text { are emitted }\end{array}$ & $\begin{array}{l}\text { The waste redirected to a sanitary } \\
\text { landfill site }\end{array}$ \\
\hline & Stray dog nuisance & \\
\hline & Stray cattle nuisance & \\
\hline & $\begin{array}{l}\text { Foul odour, flies and bird } \\
\text { nuisance }\end{array}$ & \\
\hline & $\begin{array}{l}\text { The lorry workers and drivers are } \\
\text { exposed to diseases }\end{array}$ & $\begin{array}{l}\text { Masks and other protective gear for } \\
\text { safety }\end{array}$ \\
\hline $\begin{array}{l}\text { Rag pickers retrieve the } \\
\text { recyclable material from } \\
\text { the landfill }\end{array}$ & High exposure to diseases & $\begin{array}{l}\text { Masks and other protective gear for } \\
\text { safety }\end{array}$ \\
\hline
\end{tabular}

\begin{tabular}{|c|c|c|}
\hline $\begin{array}{l}\text { Koramangala } \\
\text { Population- } 45929 \\
\text { Area- } 3.692\end{array}$ & & \\
\hline Storage & No community bins & $\begin{array}{l}100 \% \text { of the area is covered by } \\
\text { door to door collection }\end{array}$ \\
\hline Collection & $\begin{array}{l}\text { Community Bins } \\
\text { Door to door method } \\
\text { Once in day }\end{array}$ & $100 \%$ door to door collection \\
\hline Transfer & $\begin{array}{l}\text { No transfer station } \\
\text { Truck with mesh-4 } \\
\text { Truck with mesh and } \\
\text { polythene-3 }\end{array}$ & $\begin{array}{l}\text { Direct transport to disposal } \\
\text { yard } \\
100 \% \text { of the trucks have mesh } \\
\text { cover } \\
75 \% \text { of the trucks have } \\
\text { polythene cover }\end{array}$ \\
\hline Process & $\begin{array}{l}\text { Composting (KCDC) } \\
\text { Intake 300MT/day } \\
\text { Compost yard- } 1.69433 \\
\text { hectare } \\
\text { Composting of 100MT/day of } \\
\text { compost requires } 1 \text { hectare of } \\
\text { compost yard }\end{array}$ & $\begin{array}{l}3.07 \text { hectares required for } \\
\text { composting of } 300 \mathrm{MT} / \text { day of } \\
\text { MSW } \\
\text { Compost yard shortage by } \\
1.37 \text { hectares }\end{array}$ \\
\hline Disposal & Rejects sent to quarry & Open dump \\
\hline
\end{tabular}


Table 21: MSWM in Indian Institute of Science

\begin{tabular}{|c|c|c|}
\hline Function & Short coming & Suggestion \\
\hline \multicolumn{3}{|l|}{ Storage } \\
\hline \multicolumn{3}{|l|}{ Green metal bins with cover - 32} \\
\hline $\begin{array}{l}\text { Small cylindrical metal bins with } \\
\text { cover - } 16\end{array}$ & $\begin{array}{l}67 \% \text { of the bins do not } \\
\text { have cover, resulting in } \\
\text { foul odour }\end{array}$ & Provide proper enclosure for bin \\
\hline \multicolumn{3}{|c|}{\begin{tabular}{|l|l|} 
Cement concrete bins -35 & \\
\end{tabular}} \\
\hline \multicolumn{3}{|l|}{ Stone/ brick huts with cover -10} \\
\hline \multicolumn{3}{|l|}{$\begin{array}{l}\text { Open rectangular large stone bins } \\
-4\end{array}$} \\
\hline \multicolumn{3}{|l|}{ Collection } \\
\hline Door to Door method & $\begin{array}{l}\text { Drums are not painted as } \\
\text { per the regulations of } \\
\text { green for biodegradable, } \\
\text { white for recyclable and } \\
\text { black for mixed }\end{array}$ & $\begin{array}{l}\text { Painting of drums at regular } \\
\text { intervals to make it more } \\
\text { convenient to workers }\end{array}$ \\
\hline $\begin{array}{l}\text { Few of the bocks in the residential } \\
\text { area }\end{array}$ & $\begin{array}{l}\text { Waste segregated by the } \\
\text { householders to a certain } \\
\text { level }\end{array}$ & $\begin{array}{l}\text { Workers accept only segregated } \\
\text { waste from households }\end{array}$ \\
\hline \multicolumn{3}{|l|}{ Community Bin method } \\
\hline $\begin{array}{l}\text { All the departments, } \\
\text { administrative buildings, messes, } \\
\text { canteens etc. }\end{array}$ & $\left\{\begin{array}{l}\text { No separate bins provided } \\
\text { for the collection of } \\
\text { segregated waste }\end{array}\right.$ & $\begin{array}{l}\text { Provision of separate bins for } \\
\text { collection of segregated waste or } \\
\text { partition of bins }\end{array}$ \\
\hline Sweeping & $\begin{array}{l}\text { Gloves and footwear not } \\
\text { provided to workers for } \\
\text { protection }\end{array}$ & \begin{tabular}{|l|l|} 
Regular inspection of contract \\
wards by BMP
\end{tabular} \\
\hline \multicolumn{3}{|l|}{ Transfer and Transport } \\
\hline \multirow[t]{2}{*}{$\begin{array}{l}\text { The truck stops at every } \\
\text { community bin and the waste is } \\
\text { transferred from the community } \\
\text { bin to the truck }\end{array}$} & $\begin{array}{l}\text { Spillage during transfer } \\
\text { of waste from bin to truck }\end{array}$ & $\begin{array}{l}\text { Moveable bins with mechanical } \\
\text { loading collection vehicles or } \\
\text { proper equipment for transfer of } \\
\text { waste }\end{array}$ \\
\hline & Manual transfer of waste & \\
\hline $\begin{array}{l}\text { Contract truck - } 1 \text { large capacity } \\
\text { tipper, } 1 \text { small capacity tipper, } 1 \\
\text { tractor }\end{array}$ & $\begin{array}{l}\text { Mesh cover - } 1 \text { truck and } \\
1 \text { tractor, No Polythene } \\
\text { covering for all vehicles }\end{array}$ & $\begin{array}{l}\text { Trucks completely covered with } \\
\text { polythene to prevent scattering of } \\
\text { waste and foul odour }\end{array}$ \\
\hline
\end{tabular}




\begin{tabular}{|c|c|c|}
\hline & $\begin{array}{l}\begin{array}{l}\text { Foul odour and leakage of } \\
\text { truck }\end{array} \\
\end{array}$ & Provision of proper enclosure \\
\hline & $\begin{array}{l}\text { The segregated waste is } \\
\text { again mixed during } \\
\text { transfer }\end{array}$ & $\begin{array}{l}\text { A small capacity truck and a large } \\
\text { capacity truck can be assigned for } \\
\text { the collection of dry and wet waste } \\
\text { respectively. A better option is to } \\
\text { have a partition in a single truck } \\
\text { for the collection of segregated } \\
\text { waste. }\end{array}$ \\
\hline \multicolumn{3}{|l|}{\begin{tabular}{|l} 
IISc truck - 1 small capacity tipper \\
- The dry twigs, leaves, etc is \\
collected separately by this truck
\end{tabular}} \\
\hline \multicolumn{3}{|l|}{$\mid \begin{array}{lll}\text { IISc truck - } 1 \text { large capacity tipper } \\
- \text { to collect } & \text { bulky } & \text { waste } \\
\text { recyclable } & \text { waste } & \text { from } \\
\text { departments } & & \end{array}$} \\
\hline \multicolumn{3}{|l|}{ Process } \\
\hline $\begin{array}{l}\text { The litter from the vegetation that } \\
\text { is collected separately is dumped } \\
\text { in heaps in a park inside campus }\end{array}$ & $\begin{array}{l}\text { No processing of a large } \\
\text { quantity of organic waste } \\
\text { that is generated in the } \\
\text { messes }\end{array}$ & $\begin{array}{l}\text { Composting can be carried out for } \\
\text { the litter from vegetation and the } \\
\text { anaerobic digester present in the } \\
\text { campus for the processing of food } \\
\text { waste from the messes }\end{array}$ \\
\hline \multicolumn{3}{|l|}{$\begin{array}{l}\text { The Bulky and recyclable material } \\
\text { collected separately is auctioned } \\
\text { to dealers }\end{array}$} \\
\hline \multicolumn{3}{|l|}{ Disposal } \\
\hline \multirow[t]{6}{*}{ Dump yard in Betahalli } & $\begin{array}{l}\text { Foul odour, flies and bird } \\
\text { menace }\end{array}$ & $\begin{array}{l}\text { Usage of higher quantity of EM } \\
\text { solution }\end{array}$ \\
\hline & Stray dog nuisance & \\
\hline & $\begin{array}{l}\text { Waste burnt emitting } \\
\text { toxic fumes and causing } \\
\text { air pollution }\end{array}$ & $\begin{array}{l}\text { Waste burning should be } \\
\text { prohibited and strict action should } \\
\text { be taken if still continued }\end{array}$ \\
\hline & $\begin{array}{l}\text { Waste is dumped in heaps } \\
\text { causing scattering }\end{array}$ & $\begin{array}{l}\text { Usage of front end loaders for } \\
\text { leveling and use soil cover }\end{array}$ \\
\hline & Soil contamination & \\
\hline & $\begin{array}{l}\text { The lorry workers and } \\
\text { drivers are exposed to } \\
\text { diseases }\end{array}$ & Provision of masks and safety gear \\
\hline
\end{tabular}




\begin{tabular}{|l|l|l|}
\hline $\begin{array}{l}\text { Rag pickers retrieve the recyclable } \\
\text { material from the landfill }\end{array}$ & High exposure to diseases & Provision of masks and safety gear \\
\hline & & $\begin{array}{l}\text { Closure of dumpsite and replace } \\
\text { with sanitary landfill }\end{array}$ \\
\hline
\end{tabular}

\begin{tabular}{|c|c|c|}
\hline \multicolumn{3}{|c|}{$\begin{array}{l}\text { IISc } \\
\text { Population- } 2500 \\
\text { Area- } 200 \text { hectares }\end{array}$} \\
\hline Storage & $\begin{array}{l}\text { Community Bin } \\
\text { Green metal bins with cover - } 32 \\
\text { Small cylindrical metal bins with cover - } 16 \\
\text { Cement concrete bins }-35 \\
\text { Stone/ brick huts with cover - } 10 \\
\text { Open rectangular large stone bins - } 4 \\
\\
\text { Door to door- in few residential blocks }\end{array}$ & $\begin{array}{l}\text { Entire area is } \\
\text { provided with bins } \\
67 \% \text { of the bins do } \\
\text { not have cover }\end{array}$ \\
\hline Collection & $\begin{array}{l}\text { Community Bin } \\
\text { Once in day } \\
\text { Door to Door } \\
\text { Once in a day } \\
\text { Pourakarmikas- } 20\end{array}$ & $\begin{array}{l}100 \% \text { community bin } \\
10 \% \text { door to door } \\
\text { Sufficient number }\end{array}$ \\
\hline $\begin{array}{l}\text { Transfer and } \\
\text { Transport }\end{array}$ & $\begin{array}{l}\text { No transfer station } \\
\text { Number of trucks-3 } \\
\text { Truck with mesh- } 2 \\
\text { Polythene covering- } 0 \\
\end{array}$ & $\begin{array}{l}75 \% \text { trucks have mesh } \\
\text { None have polythene } \\
\text { covering }\end{array}$ \\
\hline Process & $\begin{array}{l}\text { Recycling carried out by informal sector and } \\
\text { Institute authorities } \\
\text { Vegetative litter is composted }\end{array}$ & \\
\hline Disposal & Betahalli & Open dump yard \\
\hline
\end{tabular}

The storage method adopted is community bin method. The bins are designed as per the type and quantity of waste generated. The placement of bin is uniformly distributed. This results in reduced number of overflowing bins. $67 \%$ of the bins provided are open to the atmosphere, resulting in foul odour. Few of the residential quarters have door-to-door collection that has segregation of waste at source. The waste from the bins is transferred manually to the trucks resulting in spillage of waste. All the trucks do not have polythene covering, resulting in scattering of waste and foul odour. The bulky recyclable material is collected separately and sold to the informal sector; the vegetative litter is collected separately and disposed in an area for composting. The waste id disposed in Betahalli dump yard, causing foul odour, scattering of 
waste, toxic emissions due to burning of waste and water pollution due to leachate contamination.

Table 22: MSWM in H.M.T Layout (Ward 1)

\begin{tabular}{|c|c|c|}
\hline Function & Short coming & Suggestion \\
\hline Storage & & \\
\hline $\begin{array}{l}\text { The waste is stored in the } \\
\text { households and in the } \\
\text { shops until it is collected } \\
\text { by the door to door } \\
\text { collector }\end{array}$ & & \\
\hline Collection & & \\
\hline
\end{tabular}

Door to door collection The drums are not painted as per Painting of drums at regular method adopted in thethe regulations of green for intervals to make it more entire ward biodegradable, white for convenient to workers

\begin{tabular}{|c|c|c|}
\hline 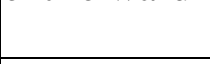 & recyclable and black for mixed & 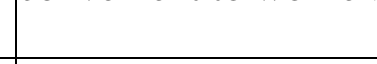 \\
\hline & $\begin{array}{l}\text { No segregation of waste b } \\
\text { householders and workers }\end{array}$ & $\begin{array}{l}\text { Workers } \\
\text { segregated } \\
\text { households }\end{array}$ \\
\hline
\end{tabular}

Recyclable waste is PET bottles and thin plastic bags retrieved by the ragare not retrieved pickers

Sweeping $\quad$ Gloves and footwear not provided Regular inspection of contract

\begin{tabular}{|l|l|l|} 
& to workers for protection & wards by BMP \\
\hline & & \\
\hline Transfer and Transport & \\
\hline The waste collected in & & \\
\hline
\end{tabular}

The waste collected in The waste even if segregated by A small capacity truck and a pushcarts from narrow the workers and stored in separatelarge capacity truck can be lanes and meet at adrums, the waste gets mixed assigned for the collection of synchronization point atduring transfer from pushcarts todry and wet waste a specified time. Thelorry. This is because there is no respectively. A better option waste is transferred fromfacility in the lorry for separate is to have a partition in a \begin{tabular}{l|l} 
the pushcart to the truck. storage of waste & single truck for the collection
\end{tabular} of segregated waste.

The lorry worker The thin plastic bags and bottles Only segregated waste should retrieves recyclableare not retrieved, the soiled be accepted to be filled into material during transfer recyclable material can not be the lorry retrieved

Contract truck - 4 large All trucks have mesh covering, Regular inspection of contract \begin{tabular}{l|l|l} 
capacity tipper trucks none have polythene covering & wards by BMP
\end{tabular} 


\begin{tabular}{|c|c|c|}
\hline & \multicolumn{2}{|c|}{\begin{tabular}{|l|l|}
$\begin{array}{l}\text { Foul odour emitted from the waste } \\
\text { during transportation }\end{array}$ & $\begin{array}{l}\text { Trucks completely covered } \\
\text { with polythene to prevent } \\
\text { scattering of waste and foul } \\
\text { odour and provision of proper } \\
\text { enclosure }\end{array}$ \\
\end{tabular}} \\
\hline & $\begin{array}{l}\text { No segregation of waste in } \\
\text { intermediate station }\end{array}$ & \begin{tabular}{|l} 
Transfer station should be \\
provided
\end{tabular} \\
\hline Process & $\begin{array}{l}\text { No processing carried out prior to } \\
\text { disposal }\end{array}$ & $\begin{array}{l}\text { Composting of the organic } \\
\text { material and retrieval of } \\
\text { recyclable waste for recycling }\end{array}$ \\
\hline & & \\
\hline \multicolumn{3}{|l|}{ Disposal } \\
\hline \multirow[t]{6}{*}{ Dump yard in Betahalli } & Foul odour, flies and bird menace & $\begin{array}{l}\text { Usage of higher quantity of } \\
\text { EM solution }\end{array}$ \\
\hline & Stray dog nuisance & \\
\hline & $\begin{array}{l}\text { Waste burnt emitting toxic fumes } \\
\text { and causing air pollution }\end{array}$ & $\begin{array}{l}\text { Waste burning should be } \\
\text { prohibited and strict action } \\
\text { should be taken if still } \\
\text { continued }\end{array}$ \\
\hline & $\begin{array}{l}\text { Waste is dumped in heaps causing } \\
\text { scattering }\end{array}$ & $\begin{array}{l}\text { Usage of front end loaders for } \\
\text { leveling and use soil cover }\end{array}$ \\
\hline & Soil contamination & \\
\hline & $\begin{array}{l}\text { The lorry workers and drivers are } \\
\text { exposed to diseases }\end{array}$ & $\begin{array}{l}\text { Provision of masks and safety } \\
\text { gear }\end{array}$ \\
\hline \multirow[t]{3}{*}{$\begin{array}{l}\text { Rag pickers retrieve the } \\
\text { recyclable material from } \\
\text { the landfill }\end{array}$} & eHigh exposure to diseases & $\begin{array}{l}\text { Provision of masks and safety } \\
\text { gear }\end{array}$ \\
\hline & & $\begin{array}{l}\text { Closure of dumpsite and } \\
\text { replace with sanitary landfill }\end{array}$ \\
\hline & Unauthorized dumping & $\begin{array}{l}\text { Identification and closure of } \\
\text { unauthorized dumps }\end{array}$ \\
\hline
\end{tabular}

\begin{tabular}{|l|l|l|}
\hline $\begin{array}{l}\text { H.M.T Layout } \\
\text { Population- 27637 } \\
\text { Area- 6.13 sq km }\end{array}$ & \\
\hline Storage & $\begin{array}{l}\text { Community bin } \\
3 \text { cement bins }\end{array}$ & \\
\hline Collection & $\begin{array}{l}\text { Community bin } \\
\text { Once in 2-3 days } \\
\text { Door to door } \\
\text { Once in a day }\end{array}$ & $100 \%$ door to door collection \\
\hline
\end{tabular}




\begin{tabular}{|l|l|l|}
\hline Transfer and Transport & $\begin{array}{l}\text { No transfer station } \\
\text { Truck-4 } \\
\text { Truck with mesh-4 } \\
\text { Truck with mesh and } \\
\text { polythene-0 } \\
\text { Pourakarmikas- } 190 \\
\text { Pushcarts-185 }\end{array}$ & $\begin{array}{l}\text { Direct transfer to disposal site } \\
\text { 0\% polythene cover } \\
\text { Sufficient number of } \\
\text { pourakarmikas and pushcarts }\end{array}$ \\
\hline Process & $\begin{array}{l}\text { Recycling carried out by } \\
\text { informal sector }\end{array}$ & \\
\hline Disposal & Betahalli & Open dump yard \\
\hline
\end{tabular}

Door to door collection is carried out in the entire ward. There are 3 community bins present which are in a very dilapidated state. These bins are not being used to its capacity. They are all open to the atmosphere causing foul odour and unaesthetic appearance. The door-to-door collection is carried out for the entire ward. There is no segregation of waste at source. There is no transfer station present, resulting in high transportation cost and no intermediate segregation of waste. All the trucks have mesh covering, but none of the trucks have polythene cover. This results in scattering and foul odour during transportation. The recycling of waste is carried out by the informal sector that results in high efficiency of recyclable waste recovery. However, the PET and thin plastic bags are avoided. The waste is then directly disposed to the Betahalli dump yard causing foul odour, scattering of waste, water pollution through leachate contamination and emission of toxic gases. 
Table 23: MSWM in Airport Road (Ward 73)

\begin{tabular}{|c|c|c|}
\hline Function & Short coming & Suggestion \\
\hline \multicolumn{3}{|l|}{ Storage } \\
\hline \multicolumn{3}{|l|}{$\begin{array}{l}\text { The waste is stored in the } \\
\text { households and in the } \\
\text { shops until it is collected } \\
\text { by the door to door } \\
\text { collector }\end{array}$} \\
\hline \multicolumn{3}{|l|}{ Collection } \\
\hline \multirow{2}{*}{\begin{tabular}{|l|} 
Door to door collection \\
method adopted in the \\
entire ward
\end{tabular}} & \begin{tabular}{|l} 
The drums are not painted as per \\
the regulations of green for \\
biodegradable, white \\
recyclable and black for mixed
\end{tabular} & $\begin{array}{l}\text { Painting of drums at regular } \\
\text { fintervals to make it more } \\
\text { convenient to workers }\end{array}$ \\
\hline & $\begin{array}{l}\text { There is no segregation of waste } \\
\text { by householders and workers }\end{array}$ & $\begin{array}{l}\text { Workers accept only segregated } \\
\text { waste from households }\end{array}$ \\
\hline $\begin{array}{l}\text { The recyclable waste is } \\
\text { retrieved by the worker } \\
\text { and sells it separately to } \\
\text { the informal sector }\end{array}$ & $\begin{array}{l}\text { PET bottles and thin plastic bags } \\
\begin{array}{l}\text { are not retrieved. The soiled } \\
\text { recyclable material cannot be } \\
\text { retrieved. }\end{array} \\
\end{array}$ & \\
\hline \multirow[t]{2}{*}{\begin{tabular}{|l|l} 
Sweeping & t \\
\end{tabular}} & $\begin{array}{l}\text { Gloves and footwear not provided } \\
\text { to workers for protection }\end{array}$ & $\begin{array}{l}\text { Regular inspection of contract } \\
\text { wards by BMP }\end{array}$ \\
\hline & $\begin{array}{l}\text { The dirt is pushed into the drains } \\
\text { which blocks the drains }\end{array}$ & $\begin{array}{l}\text { Workers educated on effect of } \\
\text { blocked drains and regular } \\
\text { inspection of drains }\end{array}$ \\
\hline \multicolumn{3}{|c|}{\begin{tabular}{|l|l|} 
Transfer and Transport & \\
\end{tabular}} \\
\hline \multicolumn{2}{|c|}{$\begin{array}{l}\text { The waste collected in The waste even if segregated by } \\
\text { pushcarts from narrow the workers and stored in separate } \\
\text { lanes and meet at a drums, the waste gets mixed } \\
\text { synchronization point at during transfer from pushcarts to } \\
\text { a specified time. The lorry. This is because there is no } \\
\text { waste is transferred from facility in the lorry for separate } \\
\text { the pushcart to the truck. storage of waste }\end{array}$} & $\begin{array}{l}\text { A small capacity truck and a large } \\
\text { capacity truck can be assigned for } \\
\text { the collection of dry and wet waste } \\
\text { respectively. A better option is to } \\
\text { have a partition in a single truck } \\
\text { for the collection of segregated } \\
\text { waste. }\end{array}$ \\
\hline $\begin{array}{l}\text { The lorry } \text { worker } \\
\text { retrieves recyclable| } \\
\text { material during transfer } \\
\text { of waste from push cart } \\
\text { to lorry }\end{array}$ & $\begin{array}{l}\text { PET bottles and thin plastic bags } \\
\text { are not retrieved. The soiled } \\
\text { recyclable material cannot be } \\
\text { retrieved. }\end{array}$ & $\begin{array}{l}\text { Only segregated waste should be } \\
\text { accepted to be filled into the lorry }\end{array}$ \\
\hline
\end{tabular}




\begin{tabular}{|c|c|c|}
\hline $\begin{array}{l}\text { Contract truck - } 3 \text { large } \\
\text { capacity tipper trucks }\end{array}$ & $\begin{array}{l}\text { All trucks have mesh covering, } \\
\text { none have polythene covering }\end{array}$ & \begin{tabular}{|l|l|} 
Regular inspection of contract \\
wards by BMP
\end{tabular} \\
\hline & \begin{tabular}{|l|} 
There is leakage of wet waste from \\
truck during transportation
\end{tabular} & $\begin{array}{l}\text { Trucks completely covered with } \\
\text { polythene to prevent scattering of } \\
\text { waste and foul odour }\end{array}$ \\
\hline & $\begin{array}{l}\text { Foul odour emitted from the waste } \\
\text { during transportation }\end{array}$ & Provision of proper enclosure \\
\hline & & Regular inspections \\
\hline & $\begin{array}{l}\text { No segregation of waste in } \\
\text { intermediate station }\end{array}$ & Transfer station \\
\hline \multicolumn{3}{|l|}{ Process } \\
\hline \multirow[t]{2}{*}{$\begin{array}{l}\text { Currently no process in } \\
\text { place }\end{array}$} & & \begin{tabular}{|l|} 
Recycling material should be \\
retrieved for recycling
\end{tabular} \\
\hline & & $\begin{array}{l}\text { The organic material transported to } \\
\text { a compost plant }\end{array}$ \\
\hline \multicolumn{3}{|l|}{ Disposal } \\
\hline K R Puram & Foul odour, flies and bird nuisance & $\begin{array}{l}\text { Identification and closure of dump } \\
\text { sites }\end{array}$ \\
\hline \multirow[t]{5}{*}{ 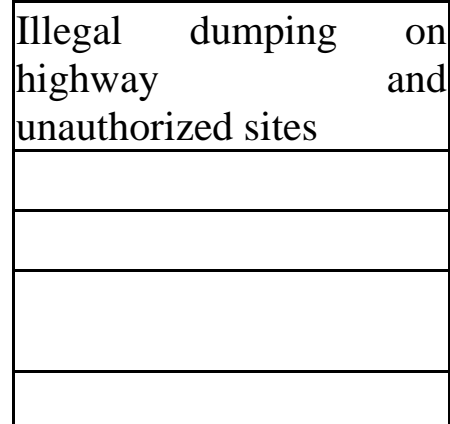 } & Stray dog nuisance & \\
\hline & Soil contamination & \\
\hline & Lake water contamination & \\
\hline & $\begin{array}{l}\text { Burning of waste emitting toxic } \\
\text { fumes }\end{array}$ & \\
\hline & Scattering of waste & \\
\hline
\end{tabular}

\begin{tabular}{|c|c|c|}
\hline $\begin{array}{l}\text { Airport Road } \\
\text { Population-42288 } \\
\text { Area- } 6.66 \mathrm{sq} \mathrm{km}\end{array}$ & & \\
\hline Storage & No community bins & $\begin{array}{l}100 \% \text { of the area is covered by } \\
\text { door to door collection }\end{array}$ \\
\hline Collection & $\begin{array}{l}\text { Community Bins } \\
\text { Door to door method } \\
\text { Once in a day } \\
\text { Pourakarmikas-120 } \\
\text { Pushcarts- } 100\end{array}$ & $100 \%$ door to door collection \\
\hline Transfer and transport & $\begin{array}{l}\text { No transfer station } \\
\text { Trucks - } 3\end{array}$ & $\begin{array}{l}\text { Direct transport to disposal } \\
\text { yard }\end{array}$ \\
\hline
\end{tabular}




\begin{tabular}{|l|l|l|}
\hline & $\begin{array}{l}\text { Truck with Mesh cover- 3 } \\
\text { Truck with mesh and } \\
\text { polythene cover- 0 }\end{array}$ & $\begin{array}{l}100 \% \text { mesh cover } \\
0 \% \text { polythene cover }\end{array}$ \\
\hline Process & $\begin{array}{l}\text { Recycling carried out by } \\
\text { informal sector }\end{array}$ & \\
\hline Disposal & K R Puram & Open dump \\
\hline
\end{tabular}

The door-to-door collection method has been adopted in entire area; there are no community bins present which has improved the aesthetic appearance of the area. There is no segregation at source implemented. All the trucks have mesh cover, but no polythene cover, resulting in scattering of waste and foul odour during transportation. The recovery and recycling of materials is carried out by the informal sector, resulting in high efficiency of recycling. However PET and thin plastic bags are not recovered. The waste is disposed in K. R. Puram open quarry. This has resulted in leachate formation of pollution of nearby water bodies. The waste is burnt causing emission of toxic gases. 
Table 24: MSWM in Chickpet (Ward 28)

\begin{tabular}{|c|c|c|}
\hline Function & Short coming & Suggestion \\
\hline \multicolumn{3}{|l|}{ Storage } \\
\hline $\begin{array}{|lrr|}\text { About } \quad(10-12) & \text { Open } \\
\text { circular cement bins }-0.9 \\
\text { m diameter and } 0.6 \mathrm{~m} 3 \\
\text { storage capacity }\end{array}$ & Few of the cement bins are broken & $\begin{array}{l}\text { Regular repair and replacement of } \\
\text { the bins }\end{array}$ \\
\hline \multirow[t]{3}{*}{$\begin{array}{l}2 \text { large Metal Bins - 1.5m } \\
\text { wide and } 1 \mathrm{~m} \text { high }\end{array}$} & $\begin{array}{l}\text { Metal bins are broken, rusted and } \\
\text { have sharp edges }\end{array}$ & Removal of rusted bins \\
\hline & $\begin{array}{l}\text { No provision for separate storage } \\
\text { of segregated waste }\end{array}$ & $\begin{array}{l}\text { Partitioned bins or separate bins } \\
\text { for different types of waste }\end{array}$ \\
\hline & $\begin{array}{l}\text { The cement and metal bins are } \\
\text { open to the atmosphere }\end{array}$ & Bins kept covered \\
\hline \multicolumn{3}{|l|}{ Collection } \\
\hline \multirow[t]{2}{*}{$\begin{array}{l}\text { Door to Door method - } \\
\text { Adopted in the whole } \\
\text { ward }\end{array}$} & $\begin{array}{l}75 \% \text { of the drums are painted as } \\
\text { per the regulations of green for } \\
\text { biodegradable, white for } \\
\text { recyclable and black for mixed }\end{array}$ & $\begin{array}{l}\begin{array}{l}\text { Painting of drums at regular } \\
\text { intervals to make it more } \\
\text { convenient to workers }\end{array}\end{array}$ \\
\hline & $\begin{array}{l}\text { Though provision has been made } \\
\text { for collection of segregated waste, } \\
\text { neither the householder nor the } \\
\text { worker segregates the waste. So } \\
\text { the waste in the mixed form is } \\
\text { collected in the drums }\end{array}$ & $\begin{array}{l}\text { Workers accept only segregated } \\
\text { waste from households }\end{array}$ \\
\hline $\begin{array}{l}\text { The recyclable waste is } \\
\text { retrieved by the worker } \\
\text { and sells it separately to } \\
\text { the informal sector }\end{array}$ & $\begin{array}{l}\text { PET bottles and thin plastic bags } \\
\text { are not retrieved. } \\
\text { recyclable material cannot be } \\
\text { retrieved. }\end{array}$ & \\
\hline \multirow{2}{*}{$\begin{array}{l}\text { Community bin method - } \\
\text { few old bins present in } \\
\text { residential area and 2 } \\
\text { large metal bins present } \\
\text { in commercial area } \\
\end{array}$} & $\begin{array}{l}\text { Heaps of waste found on road } \\
\text { sides }\end{array}$ & $\begin{array}{l}\text { Placement of few more large bins } \\
\text { in the commercial area }\end{array}$ \\
\hline & $\begin{array}{l}\text { The waste is stored in a mixed } \\
\text { form }\end{array}$ & $\begin{array}{l}\text { Provision for separate collection of } \\
\text { segregated of waste }\end{array}$ \\
\hline
\end{tabular}




\begin{tabular}{|c|c|c|}
\hline \begin{tabular}{|l|l|l} 
Recyclable material is & $\mid$ \\
retrieved by rag pickers & \\
& \\
& \\
& $r$
\end{tabular} & $\begin{array}{l}\text { PET bottles and thin plastic bags } \\
\text { are not retrieved. } \\
\text { recyclable material } \\
\text { retrieved. }\end{array}$ & \\
\hline & $\begin{array}{l}\text { There is a lot of littering on the } \\
\text { roads }\end{array}$ & $\begin{array}{l}\text { Small litter bins on road sides for } \\
\text { pedestrians }\end{array}$ \\
\hline Sweeping & $\begin{array}{l}\text { The dirt is pushed into the drains } \\
\text { which blocks the drains }\end{array}$ & $\begin{array}{l}\text { Workers educated on effect of } \\
\text { blocked drains and regular } \\
\text { inspection of drains }\end{array}$ \\
\hline & $\begin{array}{l}\text { Workers do not use the gloves and } \\
\text { footwear that are provided for } \\
\text { protection }\end{array}$ & $\begin{array}{l}\text { Mandatory usage of the protection } \\
\text { gear provided }\end{array}$ \\
\hline Transfer and Transport & & \\
\hline $\begin{array}{l}\text { The waste collected in } \\
\text { pushcarts from narrow } \\
\text { lanes and meet at a } \\
\text { synchronization point at } \\
\text { a specified time. The } \\
\text { waste is transferred from } \\
\text { the pushcart to the truck. }\end{array}$ & $\begin{array}{l}\text { The waste even if segregated by } \\
\text { the workers and stored in separate } \\
\text { drums, the waste gets mixed } \\
\text { during transfer from pushcarts to } \\
\text { lorry. This is because there is no } \\
\text { facility in the lorry for separate } \\
\text { storage of waste }\end{array}$ & $\begin{array}{l}\text { A small capacity truck and a large } \\
\text { capacity truck can be assigned for } \\
\text { the collection of dry and wet waste } \\
\text { respectively. A better option is to } \\
\text { have a partition in a single truck } \\
\text { for the collection of segregated } \\
\text { waste. }\end{array}$ \\
\hline $\begin{array}{l}\text { The lorry } \\
\text { retrieves } \\
\text { material during transfer } \\
\text { of waste from push cart }\end{array}$ & $\begin{array}{l}\text { PET bottles and thin plastic bags } \\
\text { are not retrieved. } \\
\text { recyclable material } \\
\text { retrieved. }\end{array}$ & $\begin{array}{l}\text { Only segregated waste should be } \\
\text { accepted to be filled into the lorry }\end{array}$ \\
\hline & Manual transfer of waste & $\begin{array}{l}\text { Mechanical loading collection } \\
\text { vehicles or proper equipment for } \\
\text { transfer of waste }\end{array}$ \\
\hline & $\begin{array}{l}\text { During transfer of waste from bins } \\
\text { to trucks, there is a small amount } \\
\text { of spillage and the waste is not } \\
\text { completely cleared out }\end{array}$ & $\begin{array}{l}\text { Mechanically loading collection } \\
\text { vehicles or trained personnel }\end{array}$ \\
\hline \begin{tabular}{|lr} 
BMP truck - 5 Large \\
capacity tipper & - All \\
trucks have a mesh & and \\
Polythene Sheet covering
\end{tabular} & $\begin{array}{l}\text { The waste is not segregated at an } \\
\text { intermediate level and is directly } \\
\text { transported to the disposal site }\end{array}$ & $\begin{array}{l}\text { Transfer stations need to be } \\
\text { introduced in cities where waste } \\
\text { can be further segregated and } \\
\text { higher efficiency for transportation }\end{array}$ \\
\hline & $\begin{array}{l}\text { Long distance from ward to dump } \\
\text { site, hence only one trip a day is } \\
\text { made by each truck }\end{array}$ & number of trips made by each truck \\
\hline
\end{tabular}




\begin{tabular}{|c|c|c|}
\hline \multirow[t]{2}{*}{ Process } & \multirow[t]{2}{*}{$\begin{array}{l}\text { No processing carried out prior to } \\
\text { disposal }\end{array}$} & \multirow{2}{*}{\begin{tabular}{|l|} 
Retrieval of recyclable material \\
$\begin{array}{l}\text { The organic matter can be } \\
\text { transported to a compost plant }\end{array}$ \\
\end{tabular}} \\
\hline & & \\
\hline \multicolumn{3}{|l|}{ Disposal } \\
\hline \multirow[t]{6}{*}{ Dump yard in Betahalli } & Foul odour, flies and bird menace & $\begin{array}{l}\text { Usage of higher quantity of EM } \\
\text { solution }\end{array}$ \\
\hline & Stray dog nuisance & \\
\hline & $\begin{array}{l}\text { Waste burnt emitting toxic fumes } \\
\text { and causing air pollution }\end{array}$ & $\begin{array}{l}\text { Waste burning should be } \\
\text { prohibited and strict action should } \\
\text { be taken if still continued }\end{array}$ \\
\hline & $\begin{array}{l}\text { Waste is dumped in heaps causing } \\
\text { scattering }\end{array}$ & $\begin{array}{l}\text { Usage of front end loaders for } \\
\text { leveling and use soil cover }\end{array}$ \\
\hline & Soil contamination & \\
\hline & $\begin{array}{l}\text { The lorry workers and drivers are } \\
\text { exposed to diseases }\end{array}$ & Provision of masks and safety gear \\
\hline \multirow[t]{2}{*}{$\begin{array}{l}\text { Rag pickers retrieve the } \\
\text { recyclable material from } \\
\text { the landfill }\end{array}$} & High exposure to diseases & Provision of masks and safety gear \\
\hline & & $\begin{array}{l}\text { Closure of dumpsite and replace } \\
\text { with sanitary landfill }\end{array}$ \\
\hline
\end{tabular}

\begin{tabular}{|c|c|c|}
\hline $\begin{array}{l}\text { Chikpet } \\
\text { Population- } 31851 \\
\text { Area- } 0.94 \mathrm{sq} \mathrm{km}\end{array}$ & & \\
\hline Storage & $\begin{array}{l}\text { Community Bin } \\
\text { Open circular cement bins - } \\
0.9 \text { m diameter and } 0.6 \mathrm{~m} 3 \\
\text { storage capacity- } 12 \\
\text { Metal Bins - } 1.5 \mathrm{~m} \text { wide and } \\
1 \mathrm{~m} \text { high- } 2\end{array}$ & $\begin{array}{l}16 \% \text { of the bins are provided } \\
\text { with cover }\end{array}$ \\
\hline Collection & $\begin{array}{l}\text { Community Bin } \\
\text { Door to door }\end{array}$ & $\begin{array}{l}\text { Community bins are provided } \\
\text { in commercial areas, } 30 \% \text { of } \\
\text { area } \\
\begin{array}{l}\text { Door to door for the entire } \\
\text { area }\end{array}\end{array}$ \\
\hline Transfer and Transport & $\begin{array}{l}\text { No transfer station } \\
\text { Trucks-5 } \\
\text { Truck with mesh-5 } \\
\text { Truck with mesh and } \\
\text { polythene-5 }\end{array}$ & $\begin{array}{l}\text { Disposed directly to transfer } \\
\text { site } \\
100 \% \text { of the trucks have mesh } \\
\text { and polythene covering }\end{array}$ \\
\hline Process & Recycling carried out by & \\
\hline
\end{tabular}




\begin{tabular}{|l|l|l|}
\hline & informal sector & \\
\hline Disposal & Betahalli & Open dump yard \\
\hline
\end{tabular}

Community bin and door-to-door method of collection is adopted in this commercial area. The community bins are not well maintained that has resulted in rusting of bins and broken bins with sharp edges. Only $16 \%$ of the bins have covered resulting in foul odour, spread of germs and scattering of waste. The bins are not designed as per the generation of waste and not properly placed resulting in overflowing bins. The bins are also not sufficient in number. The door-todoor method adopted is not sufficient for collection of waste in a crowded commercial area like Chikpet. The segregation of waste is not taking place during collection. There is no transfer station present and the waste is directly disposed in dump, resulting in high transportation cost. There is also no processing of waste that is done prior to disposal. The waste is disposed in Betahalli dump yard causing foul odour, scattering of waste, water pollution through leachate contamination and emission of toxic gases. 
Table 25: Overall Result of the wards

\begin{tabular}{|c|c|c|c|c|c|c|c|c|c|c|}
\hline Function & Technique & & $\begin{array}{l}\text { Shivajin } \\
\text { agar }\end{array}$ & $\begin{array}{l}\text { Mallesw } \\
\text { aram }\end{array}$ & $\begin{array}{l}\text { Koram } \\
\text { angala }\end{array}$ & IISc & H.M.T & $\begin{array}{l}\text { Airport } \\
\text { Road }\end{array}$ & Chickpet & $\begin{array}{l}\text { Average } \\
\text { \%age }\end{array}$ \\
\hline Storage & $\begin{array}{l}\text { Community } \\
\text { bin }\end{array}$ & $\begin{array}{l}\% \text { Of covered } \\
\text { bins }\end{array}$ & 30 & & & 33 & & & 84 & 49.00 \\
\hline Collection & $\begin{array}{l}\text { Community } \\
\text { bin }\end{array}$ & $\begin{array}{l}\% \text { Area covered } \\
\text { in commercial } \\
\text { areas }\end{array}$ & 40 & 0 & 0 & 100 & 2 & 0 & 30 & 34.40 \\
\hline & $\begin{array}{l}\text { Door to } \\
\text { door }\end{array}$ & $\begin{array}{l}\text { \% Area covered } \\
\text { in residential } \\
\text { areas }\end{array}$ & 100 & 100 & 100 & 60 & 100 & 100 & 100 & 94.29 \\
\hline & & $\begin{array}{l}\% \text { Of waste } \\
\text { segregated }\end{array}$ & 0 & 0 & 20 & 5 & 0 & 0 & 0 & 3.57 \\
\hline Transfer & & Transfer station & A & $A$ & $A$ & $A$ & $A$ & $A$ & $A$ & $A$ \\
\hline Transport & Truck & $\begin{array}{l}\text { Truck with mesh } \\
\%\end{array}$ & 100 & 100 & 100 & 75 & 100 & 100 & 100 & 96.43 \\
\hline & & $\begin{array}{l}\text { Truck with mesh } \\
\text { and polythene } \\
\text { cover \% }\end{array}$ & 75 & 40 & 75 & 0 & 0 & 0 & 100 & 41.43 \\
\hline Process & \begin{tabular}{|l}
$\%$ Of \\
waste \\
recycled
\end{tabular} & Informal & 18 & 18 & 18 & 18 & 18 & 18 & 18 & 18.00 \\
\hline & & Formal & & & & & & & & \\
\hline & \begin{tabular}{|l|}
$\%$ Of \\
waste \\
composted
\end{tabular} & & & & 22 & & & & & 3.14 \\
\hline & \begin{tabular}{|l|}
$\%$ Of \\
waste for \\
anaerobic \\
digestion
\end{tabular} & & & & & & & & & \\
\hline & $\begin{array}{l}\% \text { Of } \\
\text { waste } \\
\text { incinerated }\end{array}$ & & & & & & & & & \\
\hline Disposal & \begin{tabular}{|l|} 
Sanitary \\
landfill
\end{tabular} & & & & & & & & & \\
\hline & Dump yard & & 85 & 85 & & 85 & 85 & & 85 & 60.71 \\
\hline & Quarry & & & & 63 & & & 85 & & 21.14 \\
\hline
\end{tabular}

Considering the above wards to be a representative sample of Bangalore city, we can infer the following: In Bangalore the waste is stored in open or closed community bins. Out of the community bins present the average percentage of bins covered is $49 \%$. The collection of the waste is carried out by community bin method and door-to-door method. From the previous explanations, we know that it is essential that we have community bins along with door-to-door collection in commercial areas. The percentage of area covered by community bin in commercial areas is 34\%. Door to door collection method has been implemented in all areas of 
the city as it is a suitable method for collection from residential areas and also suitable for collection of segregated waste. In Bangalore door-to-door collection has been implemented in $94 \%$ of the residential areas. However, only $3 \%$ of the waste is segregated at source. There are currently no transfer stations in Bangalore and all the waste is directly transported to the disposal site. This is very expensive and the efficiency of the trucks is not utilized to the maximum. As per regulations all trucks should have mesh and polythene covering. However, only $96 \%$ of the trucks have mesh covering and $41.43 \%$ of the trucks have polythene covering. The quantity of waste processed is very low. The informal sector in the city manages the recycling sector, 18\% of the total waste generated is recycled by this sector. The other process method adopted in the city is composting. $3.14 \%$ of the waste is reduced through composting. The final quantity of waste sent to the dump yard and quarry (open dump) is $60.71 \%$ and 21.14 respectively. 
Table 26: Technique adopted and Resource management in all wards

\begin{tabular}{|c|c|c|c|c|c|c|c|c|c|}
\hline \multicolumn{3}{|c|}{ Resource management } & & & & & & & \\
\hline & & & \multicolumn{7}{|c|}{ Ward name and Number } \\
\hline $\begin{array}{l}\text { Functional } \\
\text { element }\end{array}$ & Technique & Resource & \begin{tabular}{|l|} 
Shivaji \\
nagar \\
79
\end{tabular} & $\begin{array}{l}\text { Mallesw } \\
\text { aram } 7\end{array}$ & $\begin{array}{l}\text { Koraman } \\
\text { gala } 67\end{array}$ & IISc & $\begin{array}{l}\text { HMT } \\
1\end{array}$ & $\begin{array}{l}\text { Airport } \\
\text { Road } \\
73\end{array}$ & $\begin{array}{l}\text { Chick } \\
\text { pet } 28\end{array}$ \\
\hline \multirow[t]{5}{*}{ Storage } & $\begin{array}{l}\text { Community } \\
\text { bin }\end{array}$ & Cement bin with cover & & & & & & & \\
\hline & & Cement bin without cover & $\mathrm{V}$ & & & $\mathrm{V}$ & $\mathrm{V}$ & & V \\
\hline & & Metal bin with cover & $\mathrm{V}$ & & & & & & $\mathrm{V}$ \\
\hline & & Metal bin without cover & & & & & & & \\
\hline & $\begin{array}{ll}\text { Door } & \text { to } \\
\text { door } & \end{array}$ & Push cart with drum & $\mathrm{V}$ & $\mathrm{V}$ & $\mathrm{V}$ & $\mathrm{V}$ & $\mathrm{V}$ & $\mathrm{V}$ & $\mathrm{V}$ \\
\hline \multirow[t]{5}{*}{ Collection } & $\begin{array}{l}\text { Community } \\
\text { bin }\end{array}$ & Bin without partition & $\mathrm{V}$ & & & $\mathrm{V}$ & $\mathrm{V}$ & & $\mathrm{V}$ \\
\hline & & \begin{tabular}{|l}
$\begin{array}{l}\text { Bin with partition with } \\
\text { segregation }\end{array}$ \\
\end{tabular} & & & & & & & \\
\hline & $\begin{array}{l}\text { Door } \\
\text { door }\end{array}$ & $\begin{array}{l}\text { Push cart with drum (with } \\
\text { segregation) }\end{array}$ & & & & & & & \\
\hline & & $\begin{array}{l}\text { Pushcart with drum (without } \\
\text { segregation) }\end{array}$ & $\mathrm{V}$ & V & $\mathrm{V}$ & $\mathrm{V}$ & $\mathrm{V}$ & $\mathrm{V}$ & $\mathrm{V}$ \\
\hline & & \begin{tabular}{|l|l} 
Pourakarmikas & I \\
\end{tabular} & $\mathrm{V}$ & $\mathrm{V}$ & $\mathrm{V}$ & $\mathrm{V}$ & V & $\mathrm{V}$ & V \\
\hline \multirow[t]{3}{*}{ Transfer } & & $\begin{array}{l}\text { Lorry with partition for } \\
\text { collection of segregated } \\
\text { waste }\end{array}$ & & & & & & & \\
\hline & & Lorry with out partition & $\mathrm{V}$ & V & V & $\mathrm{V}$ & V & $\mathrm{V}$ & $\mathrm{V}$ \\
\hline & & Lorry worker & $\mathrm{V}$ & V & V & V & $\mathrm{V}$ & $\mathrm{V}$ & $\mathrm{V}$ \\
\hline \multirow[t]{2}{*}{ Transport } & & Lorry with mesh cover & $\mathrm{V}$ & V & $\mathrm{V}$ & $\mathrm{V}$ & $\mathrm{V}$ & $\mathrm{V}$ & $\mathrm{V}$ \\
\hline & & \begin{tabular}{|l} 
Lorry with mesh and \\
polythene cover
\end{tabular} & & & & & & & $\mathrm{V}$ \\
\hline \multirow[t]{5}{*}{ Process } & \begin{tabular}{|l|} 
Anaerobic \\
digestion
\end{tabular} & & & & & & & & \\
\hline & Incineration & & & & & & & & \\
\hline & Recycling & Recycling by formal sector & & & & & & & \\
\hline & & Recycling by informal sector & $\mathrm{V}$ & $\mathrm{V}$ & V & $\mathrm{V}$ & $\mathrm{V}$ & $\mathrm{V}$ & $\mathrm{V}$ \\
\hline & Composting & & & & $\mathrm{V}$ & & & & \\
\hline
\end{tabular}




\begin{tabular}{|c|c|c|c|c|c|c|c|c|c|}
\hline & & Compost yard present & & & $\mathrm{V}$ & & & & \\
\hline & & Rotary screen present & & & V & & & & \\
\hline & & Front end loaders present & & & $\mathrm{V}$ & & & & \\
\hline Disposal & $\begin{array}{l}\text { Sanitary } \\
\text { landfill }\end{array}$ & & & & & & & & \\
\hline & Dump yard & & $\mathrm{V}$ & $\mathrm{V}$ & & $\mathrm{V}$ & $\mathrm{V}$ & & I \\
\hline & & Soil covering & & & & & & & \\
\hline & & Water spray & V & $\mathrm{V}$ & & $\mathrm{V}$ & $\mathrm{V}$ & & $\mathrm{I}$ \\
\hline & & EM solution sprayed & $\mathrm{V}$ & $\mathrm{V}$ & & $\mathrm{V}$ & $\mathrm{V}$ & & $\mathrm{T}$ \\
\hline & & Front end loaders present & $\mathrm{V}$ & $\mathrm{V}$ & & $\mathrm{V}$ & $\mathrm{V}$ & & t \\
\hline & & Rotary screens & $\mathrm{V}$ & $\mathrm{V}$ & & $\mathrm{V}$ & $\mathrm{V}$ & & $\mathrm{T}$ \\
\hline & Quarry & & & & $\mathrm{V}$ & & & $\mathrm{V}$ & \\
\hline
\end{tabular}

Table 27: Advantages and Disadvantages of Resource used

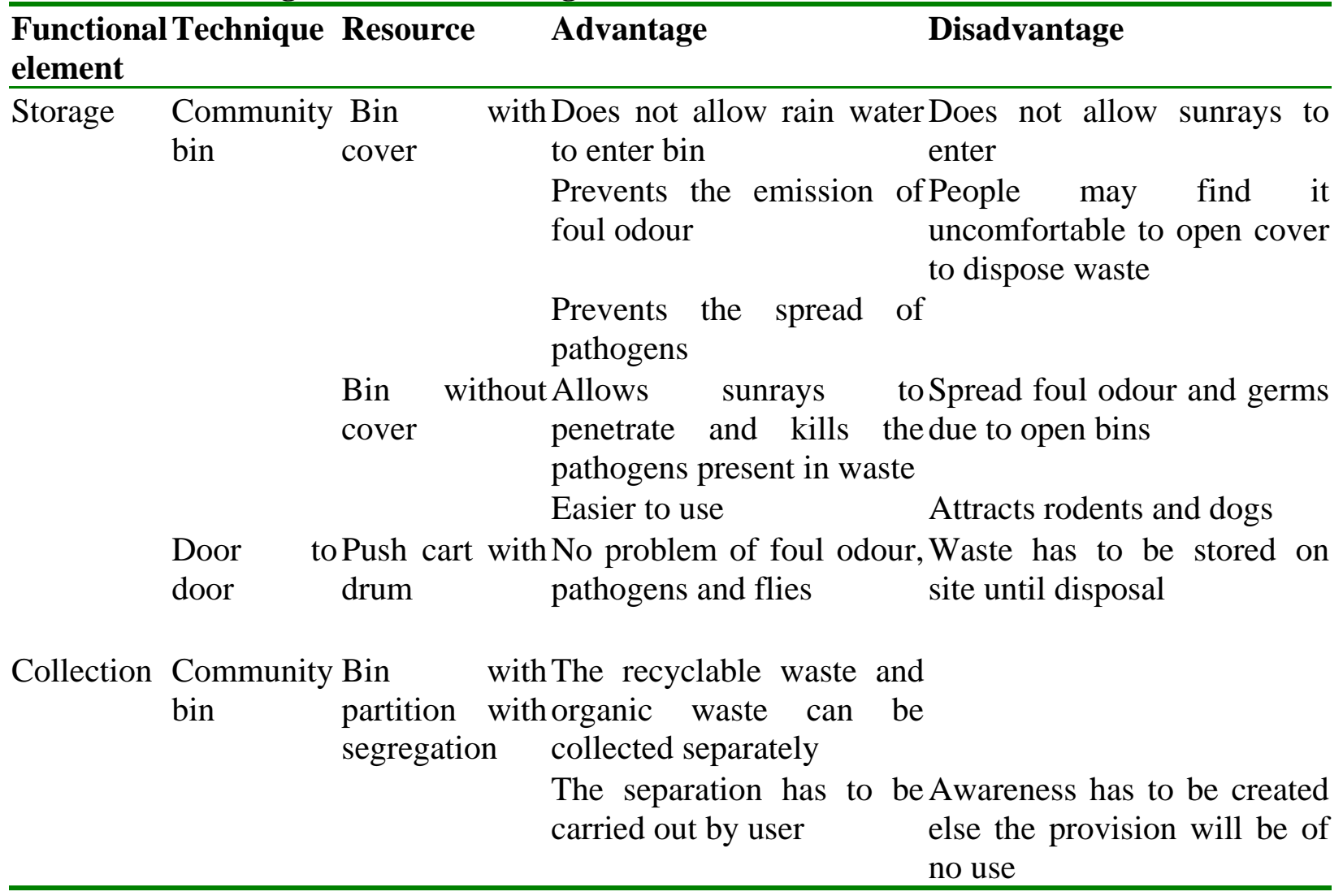




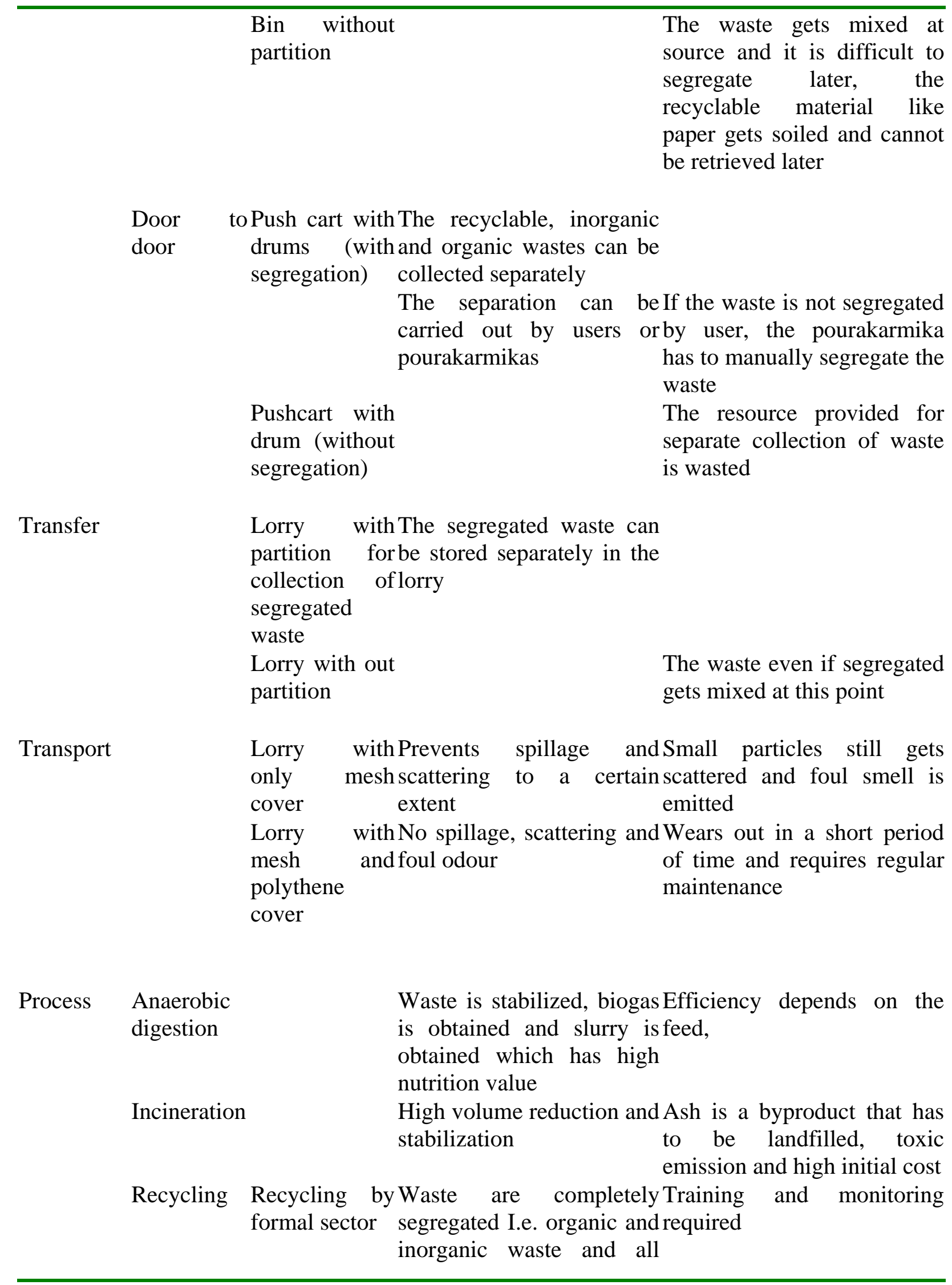




\section{recyclable materials are \\ recovered}

Recycling byHigh efficiency of PET and thin plastic bags not informal recyclable waste recovery recovered

sector and no cost to be borne by

BMP

Composting The waste can be Leachate effluent has to be composted even if not treated before disposal segregated

Volume reduction by $22 \%$

Manure is obtained

Low cost compared to other processing methods

Disposal Sanitary Waste is safely Prevents pollution, etc.

landfill disposed

Dump yard Precaution There is water and soil

taken to contamination due to

prevent foul leachate transport in the odour, flies, soil

scattering.

The waste is

stabilized

Soil covering Soil covering prevents waste from scattering, fastens the stabilization process and prevents odour

Water spray Settles the dust and helps in waste degradation

EM solution Prevents foul smell, flies sprayed and rodents

Front end Levels the waste that is loaders present dumped

Quarry

Excess number of flies, rodents, stray cattle and dogs and odour. The scattering of waste is also high.

In the Table 27 the benefits of the techniques and resources used in relation to the pollution prevention system, medical health facility and occupational health, emergency plan and safety 
Table 28: Advantages of the techniques implemented

\begin{tabular}{|c|c|c|c|c|c|}
\hline $\begin{array}{l}\text { Functional } \\
\text { Elements }\end{array}$ & ITechnique & $\begin{array}{l}\text { Pollution prevention } \\
\text { system and procedure }\end{array}$ & $\begin{array}{l}\text { Medical health facility and } \\
\text { Occupational Health }\end{array}$ & $\begin{array}{l}\text { Emergency plan and safety } \\
\text { system }\end{array}$ & $\begin{array}{l}\text { Confirmation to } \\
\text { regulatory } \\
\text { requirement }\end{array}$ \\
\hline \multirow[t]{7}{*}{ Storage } & Community Bin & & & $\begin{array}{l}\text { Community bins are better } \\
\text { suited to handle sudden } \\
\text { generation of waste, } \\
\text { especially during festivals } \\
\text { and in commercial areas }\end{array}$ & $\begin{array}{l}\text { Bins prevent littering } \\
\text { on streets }\end{array}$ \\
\hline & Bin with cover & $\begin{array}{l}\text { Bin cover prevents spread of } \\
\text { pathogens, foul odour and } \\
\text { germs }\end{array}$ & & & $\begin{array}{l}\text { Bin cover should be } \\
\text { provided as per } \\
\text { regulation }\end{array}$ \\
\hline & Bin without cover & & & & \\
\hline & Metal Bin & & $\begin{array}{l}\text { Maintenance of bins to } \\
\text { prevent rusting and regular } \\
\text { replacement of broken metal } \\
\text { bins with sharp edges. } \\
\text { Gloves provided for } \\
\text { precaution }\end{array}$ & & \\
\hline & Cement Bin & & & & \\
\hline & Door to Door & & & & \\
\hline & $\begin{array}{l}\text { Push cart with } \\
\text { drum }\end{array}$ & $\begin{array}{l}\text { Push cart store the waste } \\
\text { only for a short period of } \\
\text { time and hence do not spread } \\
\text { pathogens and does not emit } \\
\text { foul odour }\end{array}$ & $\begin{array}{l}\text { The workers manually } \\
\text { handle the waste during } \\
\text { collection and are provided } \\
\text { with gloves, footwear and } \\
\text { apron. Masks and goggles to } \\
\text { be provided for safety }\end{array}$ & $\begin{array}{l}\text { In case of hazardous } \\
\text { household waste being } \\
\text { disposed, it can be stored } \\
\text { separately by a } \\
\text { pourakarmika. Masks, } \\
\text { gloves and goggles should be } \\
\text { provided for such emergency } \\
\text { handling }\end{array}$ & $\begin{array}{l}\text { As per regulations } \\
\text { containerized carts are } \\
\text { to be used for collection } \\
\text { and transfer of waste } \\
\text { into trucks }\end{array}$ \\
\hline
\end{tabular}




\begin{tabular}{|c|c|c|c|c|c|}
\hline & & & & & $\begin{array}{l}\text { Push carts with drums } \\
\text { help in preventing } \\
\text { littering around bins, as } \\
\text { per regulations }\end{array}$ \\
\hline & & & & & $\begin{array}{l}\text { Helps in segregating at } \\
\text { source as per regulation }\end{array}$ \\
\hline & & & & & $\begin{array}{l}\text { The bins are cleared } \\
\text { every } 24 \text { hrs, bins to be } \\
\text { designed taking into } \\
\text { consideration the } \\
\text { population density }\end{array}$ \\
\hline \multirow{6}{*}{ Collection } & Community Bin & & & & \\
\hline & Bin with partition & $\begin{array}{l}\text { Waste is segregated at } \\
\text { source, making the treatment } \\
\text { process more efficient }\end{array}$ & & & \\
\hline & $\begin{array}{l}\text { Bin without } \\
\text { partition }\end{array}$ & & & & \\
\hline & Door to Door & & & & \\
\hline & $\begin{array}{l}\text { Push cart with } \\
\text { drum (with } \\
\text { segregation) }\end{array}$ & $\begin{array}{l}\text { Waste is segregated at } \\
\text { source, making the treatment } \\
\text { process more efficient }\end{array}$ & $\begin{array}{l}\text { The workers segregate the } \\
\text { waste manually during } \\
\text { collection. Hence, are } \\
\text { provided with gloves, } \\
\text { footwear and apron for } \\
\text { safety. Masks and goggles to } \\
\text { be provided for safety. }\end{array}$ & $\begin{array}{l}\text { During segregation of waste } \\
\text { the worker can get hurt or } \\
\text { infected. Every ward should } \\
\text { be provided with a first aid } \\
\text { kit }\end{array}$ & $\begin{array}{l}\text { As per regulations } \\
\text { containerized carts are } \\
\text { to be used for collection } \\
\text { and transfer of waste } \\
\text { into trucks }\end{array}$ \\
\hline & $\begin{array}{l}\text { Push cart with } \\
\text { drum (without } \\
\text { segregation) }\end{array}$ & & & & $\begin{array}{l}\text { Drums to be painted } \\
\text { green for biodegradable } \\
\text { waste, white for } \\
\text { recyclable waste and } \\
\text { black for mixed waste }\end{array}$ \\
\hline
\end{tabular}




\begin{tabular}{|c|c|c|c|c|c|}
\hline & $\begin{array}{l}\text { No manual } \\
\text { handling }\end{array}$ & & & $\begin{array}{l}\text { During manual handling of } \\
\text { waste, the worker could get } \\
\text { cut by sharp objects, to } \\
\text { prevent this gloves should be } \\
\text { provided and every ward } \\
\text { should have a first aid kit }\end{array}$ & $\begin{array}{l}\text { Manual handling } \\
\text { should be avoided as } \\
\text { per regulations }\end{array}$ \\
\hline & $\begin{array}{l}\text { Manual handling } \\
\text { with proper } \\
\text { precaution }\end{array}$ & & $\begin{array}{l}\text { For precaution the workers } \\
\text { are provided with gloves, } \\
\text { footwear and apron. Masks } \\
\text { and goggles to be provided } \\
\text { for safety }\end{array}$ & & $\begin{array}{l}\text { If manual handling is } \\
\text { carried out with } \\
\text { precaution then it } \\
\text { complies with the } \\
\text { regulations }\end{array}$ \\
\hline \multirow[t]{3}{*}{ Transfer } & $\begin{array}{l}\text { Lorry with } \\
\text { partition for } \\
\text { separate storage } \\
\text { of segregated } \\
\text { waste }\end{array}$ & $\begin{array}{l}\text { The segregated waste is } \\
\text { stored separately and } \\
\text { facilitates further treatment } \\
\text { process }\end{array}$ & & & \\
\hline & $\begin{array}{l}\text { Lorry without } \\
\text { partition }\end{array}$ & & & & \\
\hline & Manual transfer & & $\begin{array}{l}\text { The workers are provided } \\
\text { with gloves, footwear and } \\
\text { apron for safety. Masks and } \\
\text { goggles to be provided for } \\
\text { safety. }\end{array}$ & $\begin{array}{l}\text { During manual handling of } \\
\text { waste, sharp objects could } \\
\text { cut the worker, to prevent } \\
\text { this gloves should be } \\
\text { provided and every ward } \\
\text { should have a first aid kit. } \\
\text { Long exposure to waste can } \\
\text { cause eye and respiratory } \\
\text { infection, so masks and } \\
\text { goggles are to be provided. }\end{array}$ & \\
\hline
\end{tabular}




\begin{tabular}{|c|c|c|c|c|c|}
\hline & $\begin{array}{l}\text { Mechanical } \\
\text { transfer }\end{array}$ & $\begin{array}{l}\text { Mechanical transfer prevents } \\
\text { workers from coming in } \\
\text { direct contact with waste }\end{array}$ & $\begin{array}{l}\text { This method is safe, prevents } \\
\text { workers from coming in } \\
\text { contact with waste and } \\
\text { workers don't have to carry } \\
\text { heavy bins that can cause } \\
\text { accidents }\end{array}$ & $\begin{array}{l}\text { Workers can get hurt when } \\
\text { carrying heavy bins, by } \\
\text { having mechanical transfer } \\
\text { this can be prevented }\end{array}$ & $\begin{array}{l}\text { Manual handling } \\
\text { should be avoided as } \\
\text { per regulations }\end{array}$ \\
\hline \multirow[t]{3}{*}{ Transport } & $\begin{array}{l}\text { Lorry with mesh } \\
\text { cover }\end{array}$ & Prevents scattering of waste & & & $\begin{array}{l}\text { Lorry with mesh } \\
\text { complies with the rule } \\
\text { of transportation } \\
\text { vehicles should be } \\
\text { covered }\end{array}$ \\
\hline & $\begin{array}{l}\text { Lorry with mesh } \\
\text { and polythene } \\
\text { cover }\end{array}$ & $\begin{array}{l}\text { Prevents scattering, spread of } \\
\text { pathogens, dirt and foul } \\
\text { odour }\end{array}$ & & & $\begin{array}{l}\text { Polythene covering } \\
\text { complies with the law } \\
\text { of the waste not being } \\
\text { visible to the public eye } \\
\text { and not scattered during } \\
\text { transportation. }\end{array}$ \\
\hline & $\begin{array}{l}\text { Transfer station } \\
\text { for segregation of } \\
\text { waste }\end{array}$ & $\begin{array}{l}\text { Transfer station facilitates } \\
\text { intermediate segregation of } \\
\text { waste and better treatment }\end{array}$ & $\begin{array}{l}\text { Gloves, footwear, masks, } \\
\text { goggles and apron to be } \\
\text { worn during segregation of } \\
\text { waste in transfer station }\end{array}$ & $\begin{array}{l}\text { Manual segregation of waste } \\
\text { can cause accidents, so } \\
\text { proper precaution should be } \\
\text { provided like gloves and } \\
\text { aprons. Long exposure to } \\
\text { waste can cause eye and } \\
\text { respiratory infection, so } \\
\text { masks and goggles are to be } \\
\text { provided. }\end{array}$ & \\
\hline Process & $\begin{array}{l}\text { Anaerobic } \\
\text { Digestion }\end{array}$ & $\begin{array}{l}\text { Kills pathogens, stabiles } \\
\text { waste, removes foul odour } \\
\text { and fly nuisance }\end{array}$ & & & \\
\hline
\end{tabular}




\begin{tabular}{|c|c|c|c|c|}
\hline Incineration & $\begin{array}{l}\text { Kills pathogens, stabilizes } \\
\text { waste, removes foul odour } \\
\text { and fly nuisance }\end{array}$ & & & \\
\hline $\begin{array}{l}\text { Recycling by } \\
\text { formal sector }\end{array}$ & $\begin{array}{l}\text { The waste is segregated } \\
\text { completely, facilitating } \\
\text { treatment process and all } \\
\text { types of recyclables are } \\
\text { retrieved indifferent to cost }\end{array}$ & & & \\
\hline $\begin{array}{l}\text { Recycling by } \\
\text { informal sector }\end{array}$ & $\begin{array}{l}\text { High efficiency of recycling } \\
\text { achieved by this sector }\end{array}$ & & & \\
\hline Composting & $\begin{array}{l}\text { Kills germs, stabilizes waste, } \\
\text { removes foul odour and fly } \\
\text { nuisance }\end{array}$ & $\begin{array}{l}\text { A belt conveyor should be } \\
\text { provided for the safe } \\
\text { segregation of waste prior to } \\
\text { the process }\end{array}$ & $\begin{array}{l}\text { The recyclable material is } \\
\text { retrieved from heaps of } \\
\text { waste; this can prove to be } \\
\text { dangerous, sharp objects in } \\
\text { the waste can cause } \\
\text { accidents. Precaution should } \\
\text { be taken by provision of } \\
\text { gloves, footwear and apron }\end{array}$ & $\begin{array}{l}\text { Precautions is taken to } \\
\text { minimize nuisance of } \\
\text { odour, flies, rodents, } \\
\text { bird menace and fire } \\
\text { hazard }\end{array}$ \\
\hline $\begin{array}{l}\text { Windrow } \\
\text { composting- } \\
\text { impermeable base } \\
\text { layer }\end{array}$ & $\begin{array}{l}\text { Prevents the leachate from } \\
\text { leaching into the soil and } \\
\text { econtaminating soil and } \\
\text { ground water }\end{array}$ & $\begin{array}{l}\text { Gloves, footwear and apron } \\
\text { should be provided to lorry } \\
\text { drivers, JCB drivers, rag } \\
\text { pickers }\end{array}$ & & $\begin{array}{l}\text { Provided with } \\
\text { impermeable base }\end{array}$ \\
\hline & & $\begin{array}{l}\text { Provision of first aid in } \\
\text { compost plant }\end{array}$ & & $\begin{array}{l}\text { Made of concrete or } \\
\text { compacted clay, } 50 \mathrm{~cm} \\
\text { thick, having } \\
\text { permeability coefficient } \\
\text { less than } 10-7 \mathrm{~cm} / \mathrm{sec} \text {. }\end{array}$ \\
\hline
\end{tabular}




\begin{tabular}{|c|c|c|c|c|}
\hline & & $\begin{array}{l}\text { A slope is provided to collect } \\
\text { the leachate. This prevents } \\
\text { the leachate from stagnating } \\
\text { and causing mosquito } \\
\text { breeding }\end{array}$ & & $\begin{array}{l}\text { The base shall be } \\
\text { provided with } 1 \text { to } 2 \text { per } \\
\text { cent slope and circled } \\
\text { by lined drains for } \\
\text { collection of leachate or } \\
\text { surface run-off; }\end{array}$ \\
\hline & & $\begin{array}{l}\text { Leachate is treated to prevent } \\
\text { pollution of water bodies }\end{array}$ & & $\begin{array}{l}\text { Ambient air quality } \\
\text { monitoring is regularly } \\
\text { carried out }\end{array}$ \\
\hline & & & & $\begin{array}{l}\text { Compost quality as per } \\
\text { standards }\end{array}$ \\
\hline & & & & $\begin{array}{l}\text { Treated leachate should } \\
\text { comply to standards }\end{array}$ \\
\hline \multirow[t]{3}{*}{ Disposal } & Sanitary landfill & $\begin{array}{l}\text { Waste handled as per ISWM } \\
\text { principles only inert } \\
\text { materials are disposed in a } \\
\text { landfill (reduced quantity) } \\
\text { and is a safe method of } \\
\text { disposal }\end{array}$ & $\begin{array}{l}\text { Gloves, footwear and apron } \\
\text { should be provided to lorry } \\
\text { drivers, JCB drivers, rag } \\
\text { pickers }\end{array}$ & $\begin{array}{l}\text { Landfilling should be } \\
\text { restricted to inert and } \\
\text { non-biodegradable } \\
\text { waste and rejects from } \\
\text { other processing } \\
\text { facilities }\end{array}$ \\
\hline & & $\begin{array}{l}\text { Leachate collection pipes are } \\
\text { provided to prevent leachate } \\
\text { from polluting water bodies }\end{array}$ & & $\begin{array}{l}\text { Leachate collection } \\
\text { pipes, treatment for } \\
\text { leachate and non- } \\
\text { permeable lining } \\
\text { system at the base }\end{array}$ \\
\hline & & $\begin{array}{l}\text { Non-permeable lining system } \\
\text { at the base prevents leachate } \\
\text { from prevent leachate from } \\
\text { contaminating soil and water. }\end{array}$ & & \\
\hline
\end{tabular}




\begin{tabular}{|c|c|c|c|c|}
\hline Dump yard & & $\begin{array}{l}\text { Gloves, footwear and apron } \\
\text { should be provided to lorry } \\
\text { drivers, JCB drivers, rag } \\
\text { pickers }\end{array}$ & $\begin{array}{l}\text { There can be fire, due to the } \\
\text { high methane gas emission. } \\
\text { So a fire brigade should be } \\
\text { kept alert and fire emergency } \\
\text { training should be given to } \\
\text { the staff }\end{array}$ & $\begin{array}{l}\text { Should be improved to } \\
\text { the standard of sanitary } \\
\text { landfill }\end{array}$ \\
\hline & & $\begin{array}{l}\text { A belt conveyor should be } \\
\text { provided for the safe } \\
\text { segregation of waste }\end{array}$ & $\begin{array}{l}\text { Dogs and rodents are } \\
\text { rampant in dump yards. The } \\
\text { necessary medicines should } \\
\text { be kept ready in case of dog } \\
\text { or rodent bites }\end{array}$ & \\
\hline Soil covering & $\begin{array}{l}\text { Soil covering prevents waste } \\
\text { from scattering, fastens the } \\
\text { stabilization process and } \\
\text { prevents odour }\end{array}$ & & & \\
\hline Water spray & $\begin{array}{l}\text { Settles the dust and helps in } \\
\text { degradation }\end{array}$ & & & \\
\hline $\begin{array}{l}\text { EM solution } \\
\text { sprayed }\end{array}$ & $\begin{array}{l}\text { Prevents foul smell, flies and } \\
\text { rodents }\end{array}$ & & & \\
\hline $\begin{array}{l}\text { Front end loaders } \\
\text { present }\end{array}$ & $\begin{array}{l}\text { Levels waste and prevents } \\
\text { scattering }\end{array}$ & & & \\
\hline Rotary screens & & & & \\
\hline $\begin{array}{l}\text { Quarry/Open } \\
\text { dump }\end{array}$ & & $\begin{array}{l}\text { Gloves and footwear to be } \\
\text { provided to lorry drivers and } \\
\text { rag pickers }\end{array}$ & $\begin{array}{l}\text { There can be fire, due to the } \\
\text { high methane gas emission. } \\
\text { So a fire brigade should be } \\
\text { kept alert and fire emergency } \\
\text { training should be given to } \\
\text { the staff }\end{array}$ & $\begin{array}{l}\text { Open dumping is } \\
\text { prohibited }\end{array}$ \\
\hline
\end{tabular}


Dogs and rodents are

rampant in dump yards. The necessary medicines should

be kept ready in case of dog or rodent bites 
Storage: from the audit it was observed that the placement of bins has not been done keeping in mind the population density and the quantity of waste generated. There is a lack of community bins in few of the commercial area. Due to the high generation of waste in commercial areas, the waste is not always stored on site, but disposed on the roadsides causing unaesthetic appearance. Well-designed community bins have to be placed in commercial areas depending on the quantity of waste generated. The maintenance of the present bins is poor and has resulted in rusted bins having sharp edges. This can prove to be dangerous to the collection staff and also to the users. The staff must be provided with well fitting gloves for safety.

Community bins also should be provided with partition for separate collection of waste and proper coloring and labeling on the bins. To improve the separation of waste at source and throughout the MSWM process, adequate staffing, supervision, procedures, training, posters, verbal reminders, reporting, meetings and equipment are required.

Collection: Adopting door-to-door collection method has proved to have many advantages. The complaints from residents due unaesthetic bins near their houses have stopped, there is reduced number of stray dogs and stray cattle and the no bin system has also improved the waste handling by people or residents. This method is also better suited for collection of segregated waste. However, door-to-door collection method has its own considerations. In commercial areas, due to higher quantity of waste generation, the shopkeeper finds it difficult to store the waste on site and hence this waste ends up on the street.

Though separate drums have been provided for collection of segregated waste, neither the household nor the pourakarmika is carrying out segregation. This is due poor awareness and general attitude of public and pourakarmikas. The number of awareness programs and training programs carried out by the authorities need to be increased and should be at a regular frequency. It has to be kept in mind that such practices are not easy to instill and will take a many months or even years to implement. Here again adequate staffing, supervision, procedures, training, posters, verbal reminders, reporting, meetings and equipment are required to make it possible. The participation of NGOs/CBOs in such programs can prove to be very helpful to the authorities in making this a success. 
During door-to-door collection the pourakarmika manually segregates the waste. It is very important that this is carried out with proper protection like gloves. The staff should be provided with gloves, footwear, apron, masks and goggles for safety as they are in constantly exposed to waste every day.

\section{Transfer and Transport:}

The innovative idea of synchronization points that has been adopted by the municipality to transfer waste from pushcarts to trucks has proved to be successful. This has reduced the spillage, no space is occupied for intermediate storage and collection happens on time as the workers and trucks have to meet as a specified time and location for the transfer. The transfer of small drums is also much easier and safer than transfer of waste from large community bins. The trucks that are currently used do not have provision for separate collection of waste. This results to the mixing of waste even if the waste is collected separately. Trucks can either be provided with partition or two trucks can be provided. One truck for the collection of organic and mixed waste and another truck for collection of recyclable waste. The truck for recyclable waste can have a frequency of once in 3 days as the quantity of recyclable waste generated is much lesser compared to organic waste. Transfer of waste is carried out manually so it is very important to have proper safety gear like gloves, apron, masks and goggles during transfer.

The vehicles used for the transportation of waste are in a good condition. Most of the trucks have a mesh covering and about 50-60\% also have the polythene covering. However, there is no proper enclosure provided to prevent the wet waste from leaking on to the road. It is very essential that all trucks have mesh and polythene covering with a proper enclosure to prevent scattering of waste, foul odour and leakage when traveling on crowded roads.

\section{Treatment Process}

The only treatment option that is provided for Bangalore city is composting. This is carried out only for 400MT/day while the total amount of waste generated is $2300 \mathrm{MT} / \mathrm{day}$. There have been

proposals for setting up three integrated waste management sites that has composting and sanitary landfills. This actions needs to be hastened to prevent the excessive damage being caused by open dumping of large quantities of waste very day. Other treatment options also 
should be considered like decentralized anaerobic digesters near markets. This will not only produce biogas but also reduce the transportation cost of waste to landfill sites. Waste to Energy plants like production of refuse derived fuels and incineration plants can be set up to use waste from commercial areas once source segregation process is set in place.

\section{Disposal}

In the current MSWM system, the function that has been totally ignored is that of final disposal of MSW. The current method of disposal adopted as explained earlier is extremely hazardous to the environment and can cause irreversible damage to the surrounding area. The unauthorized open dumping of waste is also carried out near crowded slum areas. This is extremely hazardous to the people living around that area. The identification and closure of such dumps should be given the top most priority. The setting up the proposed sanitary landfill sites with integrated composting plants should be hastened.

Some important factors that need to be considered for the overall improvement of the waste management system are:

Data management: to improve data management there should be commitment to improving reliability of the waste data from the staff and authorities. Greater confidence in data will help in monitoring the efficiency of the collection, transportation, process and disposal option. It will also help in monitoring the unauthorized activities, by monitoring the number of trucks and trips made by trucks to the specified disposal site.

Training and Education: Environmental education is a way of increasing understanding of problems, cooperation among stakeholders, environmental entrepreneurship and environmental performance. The training should be a regular feature of MSWM. Demonstrations should be given on sorting and collection. After training there should be follow up of the practices. The staff should be made to understand the importance and the implication of their activity.

Health and Safety program: It has been a common observation that in Bangalore the staff does not use the protection gear that is provided to them. Regular health and safety programs should be carried out to educate the staff on the ill effects of manual handling of waste, walking bare foot in dump yards and continuous exposure to waste. Regular health check ups should be carried out to monitor the health of the workers. 
Involvement of the community: The community involvement in waste management monitoring programs like Suchi Mitra should be encouraged and more people should be involved in such activities. This increases the environmental awareness of the participants and the surrounding people. This is one of the fastest ways to make public understand the importance of activities like sorting.

Integration of Waste pickers: the NGOs/CBOs should organize waste pickers and methods of retrieving waste from the source by the waste pickers should be developed, instead of the waste pickers retrieving waste at the dump yard which is extremely hazardous to their health. Additionally, the waste pickers should be paid to retrieve waste from process plants and dump yards, instead of them paying to get access the waste. Ways of improving the working conditions of the waste pickers and providing safety gear for them should be developed

Planning: The waste management that is carried out currently is more of low cost measures to comply with regulation, avoid public agitation and complaints. There is no environmental management planning that is taken into consideration. Improper planning before the setting up the sanitary landfill sites has lead to increased public agitation and legal complications that have delayed the project for a very long period.

Although an informal approach to problem solving may have worked reasonably well while the program was relatively small, a more systematic and proactive approach to management is required when the complexity of the program increases. This would help to ensure that requirements are handled in a consistent and professional way and problems are addressed promptly and effectively. This would also ensure that the staff has a clear objective and goal while carrying out their activities.

Monitoring: the monitoring of the activities during collection, transfer, process and disposal needs to become an integral part of the waste management system until all the activities follow the required standard. The municipal authority not only has to monitor their own staff activities but also the activities carried out by the private organizations carrying out their services. The State pollution control board has to carry out regular inspections of the dump yards and stop open dumping as it causes serious air and water pollution problems.

Public participation: Currently the main hindrance for the implementation of the sanitary landfill sites is due to public agitation. It is very essential that before any project is implemented 
public participation meeting to make the public aware of the technology used in sanitary landfill and what will be the impacts. 


\section{FURTHER WORK}

Directions for future research emerging from this case study include a health study of waste workers, feasibility study of Waste to Energy plant and collection of methane gas from landfill site

An occupational health study of waste workers would increase knowledge about the impact on health of working with biodegradable and non-biodegradable waste streams. The study could include: identifying and assessing health concerns and causes of health effects, evaluating the adequacy of protective equipment, and comparing occupational risks from various professions. Findings from the study could be integrated in the health and safety program at the MRF to increase health awareness and develop strategies to reduce health risks.

Waste to energy plants using combustion of municipal solid waste is one of the controversial topics of today. Bangalore has also proposed to set up a Waste to Energy plant. The plant proposes to convert municipal solid waste to fuel pellets or fuel fluff to be used in industries for heating purposes. The study could bring to light if the Bangalore waste composition is suitable for such a process, select wards from which the waste composition is suitable for this process and develop segregation method in these wards.

Three landfill sites are being set up in Bangalore. All the three landfill sites do not propose collection of methane gas from landfill sites, as it is an integrated plant including composting and only the rejects will go into the landfill. Methane gas if not collected from the landfill sites, will rise into the atmosphere and will be a major contributor to global warming. The study can include investigating the composition of the rejects from a compost plant, the quantity of methane generated and the impact of the same. 


\section{CONCLUSION}

The audit has brought out the key issues that need immediate attention and minor lacunas that pose major hindrance in the further process of the system. The waste disposal needs immediate attention and strict monitoring. The setting up sanitary landfill sites has to speed up and this needs to be given top priority. The number of treatment process plants has to be increased to manage total quantity of waste generated. Many new techniques have been implemented for storage, collection, transfer and transportation. These techniques have brought about many positive changes and have increased the efficiency of the MSWM system. However, segregation of waste at each step is not being carried out. The segregation of waste during storage, collection and transportation has to be set in place for the efficient running of the process plants. Proper training and education needs to be provided to the workers and public awareness programs should be conducted regularly. The occupational and health and safety measures taken by the authorities are not sufficient. Health and safety programs has to be conducted regularly to check the health condition of the workers in the various areas of MSWM and they should be educated on the health hazards related to their work and the importance of wearing the safety gear. 


\section{REFERENCE}

A.Haque, A., Mujtaba, I.M and Bell,J. N. B., 2000. A simple model for complex waste recycling scenarios in developing economies. Waste Management 20, Issue 8, 625-63.

Agarwal, A., Singhmar, A., Kulshreshtha, M., Mittak, A. K., 2005. Municipal solid waste recycling and associated markets in Delhi, India. Resources, Conservation and Recycling 44, Issue 1, 73-90.

Ambulkar, A. R and Shekdar, A. V., 2004. Prospects of biomethanation technology in the Indian context: a pragmatic approach. Resources, Conservation and Recycling 40, Issue 2, 111128.

Association of Plastics Manufacturers in Europe (APME), 1995. Information system on plastic waste management in Western Europe: European overview, data 1997 France: APME Technical and Environmental Centre and SOFRES Counsel.

Bani Bhattacharya (March 15th 2005) Yet, life's in tatters, Down to Earth, pp. 42

Beukering, P., Sehker, M., Gerlagh, R and Kumar, V., 1999. Analysing Urban Solid Waste in Developing Countries: a Perspective on Bangalore, India. Working Paper 24, CREED, India.

Bhide, A. D. and Sundaresan, B. B., 1983. Solid Waste Management in Developing Countries. New Delhi, India: Indian National Scientific Documentation Center.

Bhoyar RV, Titus SK, Bhide AD, Khanna P., 1996. Municipal and industrial solid waste management in India, J Indian Assoc Environ Manag 23, 53-64.

Boyle, C. A (2000) Solid waste management in New Zealand. Waste Management 20, Issue 7, 517-526.

Central Pollution Control Board (СРCB), 1998. Collection, Transportation and Disposal of municipal solid wastes in Delhi (India)- a case study, Central Pollution Control Board, Delhi.

Chakraborti, N. K., 1994. Environmental Protection and the Law, Ashish Publishing house, New Delhi.

Channakya, H. N., Jagadish.K.S, and Rajabapaiah, P., 2002. Biogas plants: Towards a green and organic future. Rural Technology- A 25 year Perspective, Silver jubilee Proc. Volume 2. 
Devi, K and Satyanarayana, V., 2001. Financial resources and private sector participation in SWM in India. Indo-US Financial Reform and Expansion (FIRE) Project, New Delhi.

Dittrich, C., 2004. Bangalore: Divided under the impact of Globalization. Asia Journal of Water, environment and Pollution 2, No 2, 23-30.

DPCC (2002) Delhi pollution Control Committee, http://dpcc.delhigovt.nic.in/act_municipal.htm as on 15th May 2005

Dulac N., 2001. The organic waste flow in integrated sustainable waste management. In: Scheinberg A, editor. Integrated sustainable waste management. A set of five tools for decision-makers. Experiences from the urban waste expertise programme (1995-2001). The Netherlands: Waste Advisers on Urban Environment and Development.

Benjamin, N., (Editor) 1995. Environmental Management, UNESCO Series of Learning Materials in Engineering Sciences.

Edelmann, W., Schleiss, K and Joss, A., 2000. Ecological, energetic and economic comparison of anaerobic digestion with different competing technologies to treat biogenic waste. Water Sci. Technol. 41, 263-273.

Eiland, F., Klarner, M., Lind, M and Baath, E., 2001. Influence of Initial C/N Ratio on Chemical and Microbial Composition during Long Term Composting of Straw. Microbial Ecology 41, 272-280.

Fernandez, A. L. 1997. Introduction. In Fernandez, A. L. (ed.), K. Oya (co-ed.) and D. Dungate (co-ed.). 1997. Recycling in Asia: Partnerships for Responsive Solid Waste Management. Research Report Series No. 21. Nagoya, Japan: United Nations Centre For Regional Development (UNCRD).

Fritz, Jack. 1990. Comparatives Issues in Solid Waste Management in India and China. Paper presented at the "International Workshop on Waste Management and Resource Recovery", October 27 - November 4, Kathmandu.

Furedy, C. 1990. Social Aspects of Solid Waste Recovery in Asian Cities. Environmental Systems Review No. 30. Bangkok, Thailand: Environmental Systems Information Center (ENSIC), Asian Institute of Technology.

Garibay, S. V. and Jyothi, K., 2003. Market Opportunities and Challenges for Indian Organic products. Research Institute for Organic Agriculture and AC Nielson ORG-MARG.

Gopalakrishna (2005) The Indus Telegraph 
Gupta, S., Mohan, K., Prasad, R., Gupta, S., Kansal, A., 1998. Solid waste management in India: Options and opportunities, Resources, conservation and recycling 24, Issue 2, 137-154.

Haque, A., 1998. Limits to plastic recycling in the developing and developed economy. PhD thesis, Imperial College, London.

Harashima, Y., 2000. Environmental Governance in Selected Asian Countries. International Review for Environmental Strategies 1, no 1, 193-207.

Hester, R. E and Harrison, R. M., 2002. Environmental and Health impact of solid waste management activities, Royal Society of Chemistry, U. K.

Howard, A., 1940. An agricultural Testament, Oxford University Press, UK.

Huysman, M., 1994. A profile of Bangalore, Proceedings Workshop Linkages in Urban SWM Organized jointly by Karnataka State Council for Science and Technology, Bangalore, India and the University of Amsterdam Netherlands.

International Organisation of Supreme audit institutions (INTOSAI), 2002. Towards auditing Waste Management. INTOSAI working group on environmental Auditing.

IPE, 2004. Study of Management of Solid Waste in Indian Cities. Twelfth Finance Commission, Government of India. http://www.infrastructureindia.com/monitoreval_cs2.htm

Karadimas, N., 2004. Quality of Service Ensuring in Urban Solid Waste Management. Second IEEE International conference on intelligent system.

Kumar, S., Mondal, A. N., Gaikwad, S. A., Devotta, S., and Singh, R. N., 2004 Qualitative assessment of methane emission inventory from municipal solid waste disposal sites: a case study, Atmospheric environment 38, Issue 29, 4921- 4929.

Lardinios, I. and Klundert, van de, A. 1997 Integrated Sustainable Waste Management. Paper for the Programme Policy Meeting Urban Waste Expertise Programme. April 1997,1-6.

Linnas, R., 2001. Audit of prerequisites of implementing waste policies. Riigikontroll, Estonia, www.riiginkontroll.ee, as on $5^{\text {th }}$ June 2005

Mannan, 2002. Hazardous Waste Management- Successful practices at Asian Paints, Hyderabad. www.cleantechindia.com

Marandi, B. L., 1998. Hazardous Waste Management. Central Pollution Control Board (CPCB). http://www.cpcb.nic.in/news.htm as on 21st May 2005

Ministry of Environment and Forests (MoEF) www.envfor.nic.in as on $16^{\text {th }}$ June 2005 
Narayan, P., 2001. Analysing Plastic Waste Management in India, Case study of Polybags and PET bottles. IIIEE, Lund University, Sweden.

National Solid waste Association of India, 2003. Urban Municipal Solid Waste Management. Special Bulletin of the National Solid Waste Association of India (inaugural issue), Mumbai.

Nissim, I., Shohat, T and Inbar, Y., 2005 From dumping to sanitary landfills - solid waste management in Israel. Waste Management 25, Issue 3, 323-327

Nunan, F., 2000. Urban organic waste markets: responding to change in Hubli-Dharwad, India. Habitat International 24, Issue 3, 347-360.

Ostream, K.M., Millrath, K. and Themelis., 2004. Combining Anaerobic Digester and Waste to Energy, $12^{\text {th }}$ North American Waste to Energy Conference (NAWTEC 12), Columbia.

Ralf Buckley, 1991. Perspectives in Environmental Management, Springer-Verlag, Germany, 47-70.

Ramachandra, T. V. and Vargheses, S. K., 2003. Exploring Possibilities of Achieving Sustainability in Solid Waste Management. Indian Journal of Environmental Health 45, No 4, 255-264.

Ramasamy E.V. and Abbasi S.A., 2000. High - Solids Anaerobic Digestion for the Recovery of Energy from Municipal Solid Waste (MSW). Environmental Technology 21, 345-349.

Sachdeva, R. 2004. Private sector Participation in Municipal Solid Waste Services- An approach to sustainable waste management. Environmental Planning Collaborative, Ahmedabad, Gujarat, India.

Sathianathan, M.A., 1975. Biogas Achievements and Challenges. Assoc. Voluntary Agencies for Rural Development. New Delhi, India.

Satishkumar, R., Chanakya, H.N and Ramachandra, T. V., 2000. Feasible Solid Waste Management, CES Technical Report 85, Bangalore.

Selvam, P., 1996. A review of Indian experiences on composting of municipal solid wastes and a case study on private sector participation. Paper presented to a meeting on Recycling Waste for Agriculture: the Rural-Urban Connection, Washington, DC: The World Bank

Shekdar, A. V., 1993. A Strategy for the development for methane gas collection in developing countries. Waste management and Research 7, $111-123$. 
Shekdar, A. V., 1997. A Strategy for the development of Landfill Gas Technology in India. Waste Management and Research 15, 255-266.

Srinivas, S. V., 2003. Energy from Municipal and Industrial Wastes. Department of Chemical engineering, Indian Institute of Madras, Chennai.

Srivastava, A. K., 2003. Environment Audit, A. P. H Publishing Corporation, New Delhi.

Subramanian, K (Feb 23rd 2005) The Hindu, Chennai

Tchnobanoglous, G., Kreith, F., 2002. Handbook of Solid Waste Management, $2^{\text {nd }}$ edition, McGraw-Hill Handbooks.

Tchobanaglous, G., Theisen, H., and Eliassen, R., 1997. Solid wastes: Engineering principles and management issues. McGrawHill publications, NewYork, USA.

TERI, 2002. Energy audit of Hundai Motor India. Report No. 2002IS14. http://www.teriin.org/reports/reports.htm

TERI, 2004. Detailed energy audit of Units 1 and 2 of Relaxo Industries Limited, Bahadurgarh. Report No. 2003IE66. http://www.teriin.org/reports/reports.htm

The Expert Committee, 2000. Manual on Municipal Solid Waste Management, The Ministry of Urban Development, The Government of India, Volume 1 and 2.

The Expert Committee, 2000. Manual on Municipal Solid Waste Management. The Ministry of Urban Development, The Government of India, Volume 1 and 2.

United National Development Programme, 1991. World Bank, Regional Water and Sanitation Group for South Asia, 1991. Indian experience on composting as means of resource recovery, in: Proceedings of the UNDP/WB Water Supply and Sanitation Program Workshop on Waste Management Policies, Singapore 1-5

Vehlow, J., 1996. Municipal Solid Waste Management in Germany. Waste management 16, Issue 5, 367-374

World Health organization (2002), http://www.who.int/countries/ind/en/ as on $5^{\text {th }}$ July 2005

Zurbrügg, C., Drescher, S., Patel, A and Sharatchandra, H. C., 2004. Decentralised composting of urban waste - an overview of community and private initiatives in Indian cities. Waste Management 24, Issue 7, 655-662.

Zurbrügg, C., Drescher, S., Patel, A. H. and Sharatchandra, H. C., 2002. Decentralized Composting - An Option for Indian Cities? Report of a Workshop held in Bangalore, India. 


\section{Appendix 1}

List of Officers Interviewed

\begin{tabular}{ll}
\hline Council Officer & Mr Sridhar Murthy \\
\hline Special Commissioner & Mr. Subhash Chandra \\
Chief Health Officer & Dr Thandav Murthy \\
South Zonal Officer & Dr S. B. Nagaraj \\
West Zonal Officer & Dr Devki \\
East Zonal Officer & Dr Mala Chandra \\
Koramangala Range Officer & Dr Lokesh \\
Shivaji Nagar Range Officer & Dr Vijay Kumar S. Biradar \\
BMP Statistical department & Dr Gupta \\
Solid Waste Engineer & H.C. Anathswamy \\
Malleswaram Health Inspector & Mr Thime Gowda \\
H.M.T Health Inspector & Mr K. R. Gopinath \\
I.I.S.c MSW Contract Supervisor & Mr Srinivas \\
\hline
\end{tabular}




\section{Appendix 2}

Ward wise data

\begin{tabular}{|c|c|c|c|c|c|c|}
\hline \begin{tabular}{l|l} 
Ward & \\
Number Ward Name
\end{tabular} & Population & Area & $\begin{array}{l}\text { No. of } \\
\text { pourakarmikas }\end{array}$ & $\begin{array}{l}\text { No. of } \\
\text { pushcarts }\end{array}$ & $\begin{array}{l}\text { No. of } \\
\text { lorries }\end{array}$ & $\begin{array}{l}\text { Numbe } \\
\text { of } \\
\text { health } \\
\text { wards } \\
\end{array}$ \\
\hline 1H.M.T & 27637 & 6.13 & 71 & 185 & 4 & 2 \\
\hline 2 Jalahalli & 36125 & 3.018 & 60 & 150 & 3 & 2 \\
\hline 3 Yeshwanthpur & 46677 & 1.256 & 100 & 115 & 4 & 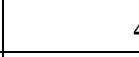 \\
\hline 4/Mathikere & 54704 & 2.031 & 135 & 135 & 4 & 2 \\
\hline 5|Kodandarama Pura & 36287 & 3.188 & 121 & 30 & 3 & : \\
\hline 6) Dattatreya Temple & 38723 & 0.87 & 88 & 40 & 2 & 2 \\
\hline 7|Malleshwaram & 37760 & 1.693 & 151 & 40 & 5 & 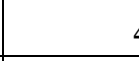 \\
\hline 8|Gayathrinagar & 40673 & 0.572 & 83 & 40 & 3 & 2 \\
\hline 9 Subramanyanagar & 38905 & 0.795 & 96 & 35 & 3 & $:$ \\
\hline 10|Mahalakshmipura & 34702 & 1.738 & & & & \\
\hline 11|Peenya Industrial Area & 35403 & 3.423 & & & & \\
\hline 12 Nandini layout & 43445 & 2.114 & 58 & 120 & 3 & $\therefore$ \\
\hline 13 Geleyara Balaga Layout & 38743 & 1.581 & 50 & 70 & 2 & 2 \\
\hline 14|Nagapur & 36918 & 1.74 & 99 & 76 & 3 & 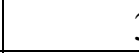 \\
\hline 15 Rajajinagara & 37005 & 1.157 & 82 & 30 & 2 & 2 \\
\hline 16|Kamalanagara & 61314 & 1.349 & 90 & 95 & 2 & 2 \\
\hline 17|Vrishabhavathi Nagara & 29275 & 0.724 & 44 & 75 & 2 & 2 \\
\hline 18|Kamakshipalya & 25742 & 0.499 & 46 & 72 & 2 & 2 \\
\hline 19 Basaveshwara Nagara & 23228 & 0.781 & 50 & 80 & 2 & 2 \\
\hline 20 Shivanagara & 28121 & 0.392 & 52 & 74 & 2 & 2 \\
\hline 21 Industrial Town & 47682 & 1.742 & 104 & 76 & 4 & - \\
\hline 22 Sri Ram Mandir & 41471 & 1.202 & 97 & 77 & 3 & 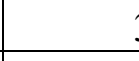 \\
\hline 23|Prakash Nagara & 35465 & 0.6 & 62 & 30 & 2 & 2 \\
\hline 24 Bashyam Nagara & 34595 & 0.276 & 70 & & 2 & 2 \\
\hline 25|Ramachandrapura & 35411 & 0.833 & 98 & 50 & 3 & 2 \\
\hline 26 Seva Ashrama & 37507 & 1.055 & 94 & 55 & 2 & 2 \\
\hline 27Gandhi Nagara & 32809 & 1.994 & 141 & 30 & 4 & 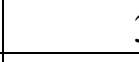 \\
\hline 28 Chickpet & 31851 & 0.94 & 149 & & 5 & $i$ \\
\hline 29 Cottonpet & 40704 & 0.925 & 104 & & 4 & 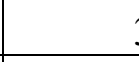 \\
\hline 30|S.K.R.Market & 39521 & 0.948 & 341 & 205 & 10 & 2 \\
\hline 31|Binnypet & 28069 & 0.301 & 86 & 71 & 2 & 2 \\
\hline 32|Kempapura Agrahara & 40047 & 0.344 & 105 & 95 & 2 & 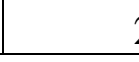 \\
\hline
\end{tabular}




\begin{tabular}{|c|c|c|c|c|c|c|}
\hline 33|Vijayanagara & 40867 & 1.042 & 64 & 50 & 2 & 2 \\
\hline 34 R.P.C.Layout & 44368 & 1.099 & 133 & 98 & 3 & 3 \\
\hline 35|Marenahalli & 40131 & 1.222 & 120 & 75 & 3 & 3 \\
\hline \begin{tabular}{l|l|}
36 & Govindaraja Nagara \\
\end{tabular} & 56340 & 1.34 & 143 & 85 & 4 & 3 \\
\hline 37|Amarjyothi Nagar & 21896 & 2.103 & 70 & 70 & 2 & 2 \\
\hline 38|Moodalapalaya & 15597 & 1.402 & 84 & 94 & 2 & 2 \\
\hline 39|Chandra Layout & 40478 & 2.166 & 70 & 84 & 3 & 3 \\
\hline 40 Atti Guppe & 25619 & 1.643 & 120 & 65 & 3 & 3 \\
\hline $\begin{array}{ll} & \text { Gali Anjaneya Swamy } \\
41 & \text { Temple }\end{array}$ & 51746 & 3.141 & 146 & 96 & 3 & 3 \\
\hline 42|Bapuji Nagar & 43223 & 0.93 & 82 & 64 & 3 & 3 \\
\hline 43 Padarayana Pura & 59933 & 0.767 & 102 & 84 & 4 & 3 \\
\hline 44Jaga Jeevana Ram Nagara & 43892 & 0.578 & 97 & 88 & 3 & 3 \\
\hline 45 Azad Nagar & 40821 & 0.757 & 139 & 105 & 3 & 3 \\
\hline 46 Chamrajpet & 40725 & 1.569 & 166 & 50 & 6 & 4 \\
\hline 47 Dharmaraya Swamy temple & 32938 & 1.092 & 149 & 40 & 6 & 4 \\
\hline 48 Sudhama Nagar & 42919 & 1.417 & 135 & 50 & 5 & 3 \\
\hline 49 Kempegowda Nagara & 41075 & 1.476 & 152 & 87 & 4 & 3 \\
\hline 50 Visweswara Puram & 31893 & 1.615 & 139 & 119 & 5 & 4 \\
\hline \begin{tabular}{|l|l|}
51 Basavanagudi \\
\end{tabular} & 39484 & 1.394 & 127 & 88 & 3 & 3 \\
\hline 52 Hanumanth Nagar & 35660 & 0.471 & 116 & 100 & 3 & 3 \\
\hline 53)Srinagar & 62163 & 1.105 & 152 & 138 & 4 & 3 \\
\hline 54 Srinivasa Nagar & 82630 & 2.137 & 140 & 120 & 4 & 4 \\
\hline 55|Padmanabha Nagar & 112407 & 6.924 & 269 & 226 & 4 & 4 \\
\hline 56 Ganesh Mandir & 87307 & 2.052 & 168 & 158 & 4 & 4 \\
\hline 57J.P.Nagar & 63906 & 4.265 & 135 & 135 & 5 & 5 \\
\hline 58 Jayanagar & 40430 & 2.132 & 159 & 122 & 5 & 4 \\
\hline 59 Yediyur & 34613 & 1.353 & 116 & 80 & 3 & 3 \\
\hline 60 Pattabhirama Nagar & 39308 & 1.343 & 138 & 90 & 4 & 3 \\
\hline 61 Mavalli & 39505 & 1.133 & 71 & 46 & 2 & 2 \\
\hline 62 Hombegowda & 53934 & 2.357 & 94 & 64 & 3 & 3 \\
\hline 63Lakkasandra & 48979 & 3.025 & 100 & 72 & 3 & 3 \\
\hline 64|Guruappanapalya & 63111 & 2.242 & 98 & 64 & 3 & 3 \\
\hline \begin{tabular}{l|l} 
65.T.M.Layout \\
\end{tabular} & 51545 & 3.992 & 160 & 80 & 4 & 4 \\
\hline 66|Madivala & 65820 & 3.415 & 143 & 104 & 5 & 4 \\
\hline 67/Koramangala & 45929 & 3.962 & 100 & 90 & 4 & 4 \\
\hline \begin{tabular}{l|l}
68 & Egipura \\
\end{tabular} & 40986 & 3.337 & 90 & 80 & & \\
\hline 69 Neelasandra & 52079 & 1.105 & 67 & 63 & & \\
\hline 70 Shanthi Nagar & 34682 & 2.174 & 69 & 40 & & \\
\hline
\end{tabular}




\begin{tabular}{|c|c|c|c|c|c|c|}
\hline 71 Austin Town & 39790 & 1.023 & 55 & 35 & & \\
\hline 72|Domlur & 44357 & 3.167 & 70 & 75 & & \\
\hline 73|Airport & 42288 & 6.661 & 120 & 100 & 4 & 4 \\
\hline 74 Jeevan bhima nagara & 39820 & 1.262 & 70 & 40 & & \\
\hline 75 Jogupalya & 36035 & 2.2 & 62 & 67 & & \\
\hline 76|Richmond Town & 36465 & 3.796 & 115 & 100 & & \\
\hline 77 Sampanginagar & 32451 & 4.326 & 192 & 99 & 5 & 5 \\
\hline 78 Vasanthnagar & 37028 & 2.237 & 140 & 124 & 5 & 5 \\
\hline 79 Shivajinagar & 34988 & 1.336 & 192 & 126 & 4 & 4 \\
\hline 80 Bharathi Nagar & 35681 & 0.706 & 25 & 26 & & \\
\hline 81Ulsoor & 39669 & 2.275 & 50 & 40 & & \\
\hline 82 Hoysala Nagar & 33359 & 1.843 & 65 & 45 & & \\
\hline 83 Sir.C.V.Raman Nagar & 50256 & 5.734 & 100 & 90 & & \\
\hline 84/Bennigana Halli & 31985 & 7.325 & 70 & 63 & & \\
\hline 85 Sarvagna Nagar & 34943 & 3.513 & 71 & 56 & & \\
\hline 86|Maruthi Seva Nagar & 39586 & 2.039 & 65 & 70 & & \\
\hline 87/Lingarajapuram & 56530 & 1.246 & 120 & 60 & & \\
\hline 88|Banaswadi & 26103 & 3.338 & 90 & 80 & & \\
\hline 89 Kacharakanahalli & 32889 & 3.828 & 70 & 65 & & \\
\hline 90|Sagayapura & 43432 & 0.611 & 52 & 30 & & \\
\hline 91 Pulikeshi Nagar & 42078 & 2.038 & 40 & 49 & & \\
\hline 92 Jayamahal & 39663 & 2.111 & 95 & 80 & & \\
\hline 93|Devara Jeevanahalli & 51578 & 1.114 & 65 & 54 & & \\
\hline 94|Kadugondanahalli & 60896 & 1.867 & 158 & 100 & & \\
\hline 95|Kaval Byrasandra & 84461 & 2.834 & 120 & 100 & & \\
\hline 96|Hebbal & 74126 & 2.372 & 100 & 50 & & \\
\hline 97/J.C.Nagar & 38042 & 1.727 & 96 & 65 & & \\
\hline 98 Ganga Nagara & 52546 & 2.774 & 155 & 80 & & \\
\hline 99Aramane Nagara & 32560 & 4.793 & 66 & 50 & & \\
\hline 100|Sanjay nagar & 52263 & 5.313 & 24 & 190 & 6 & 5 \\
\hline
\end{tabular}




\section{Appendix 3}

Photographs of Municipal solid waste management in Bangalore city

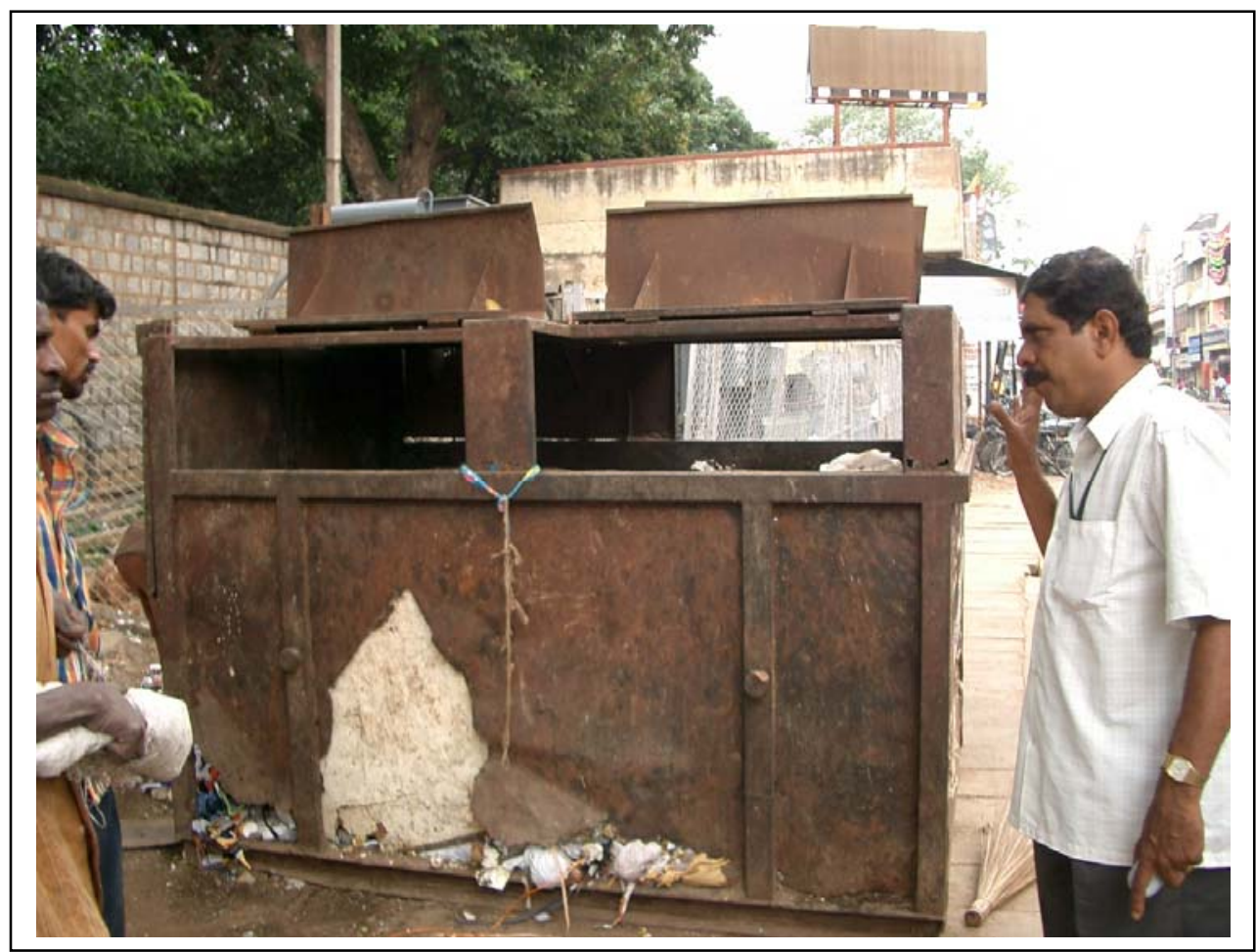

\section{Metal Bin Storage}

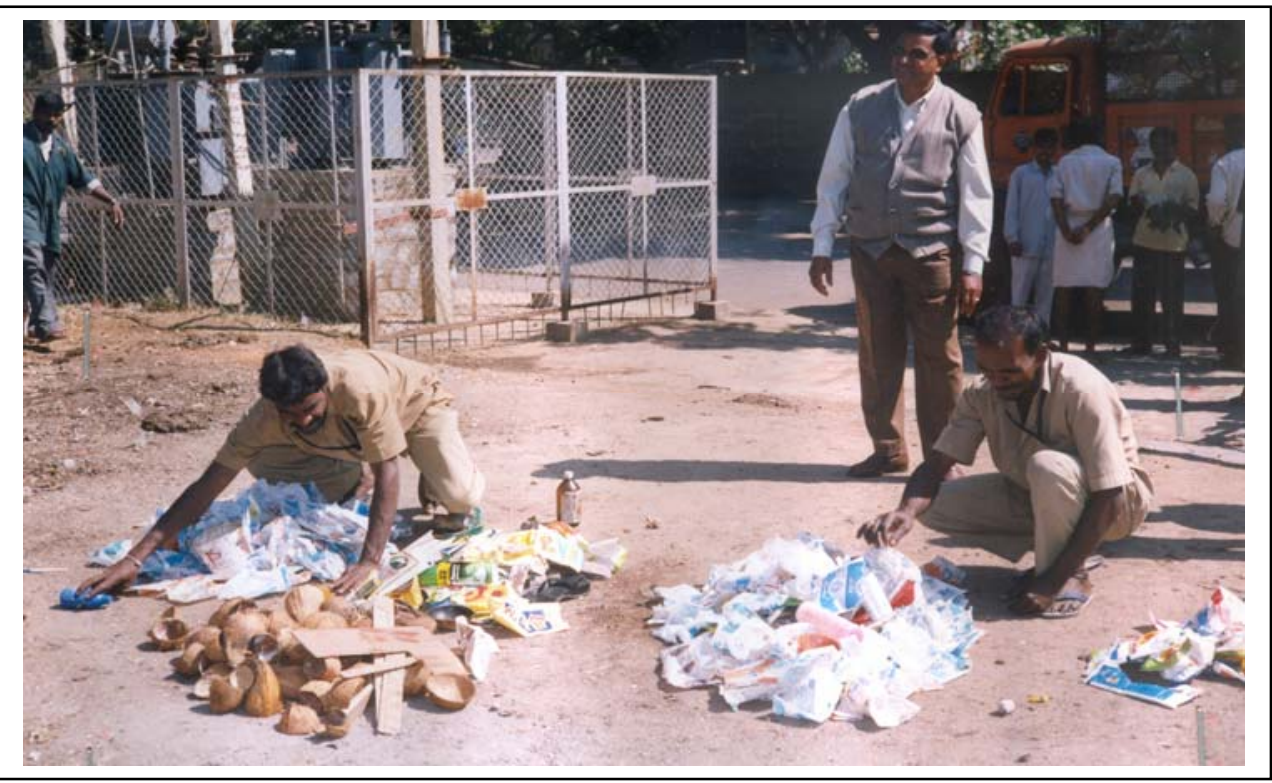

Segregation of waste by municipal workers 


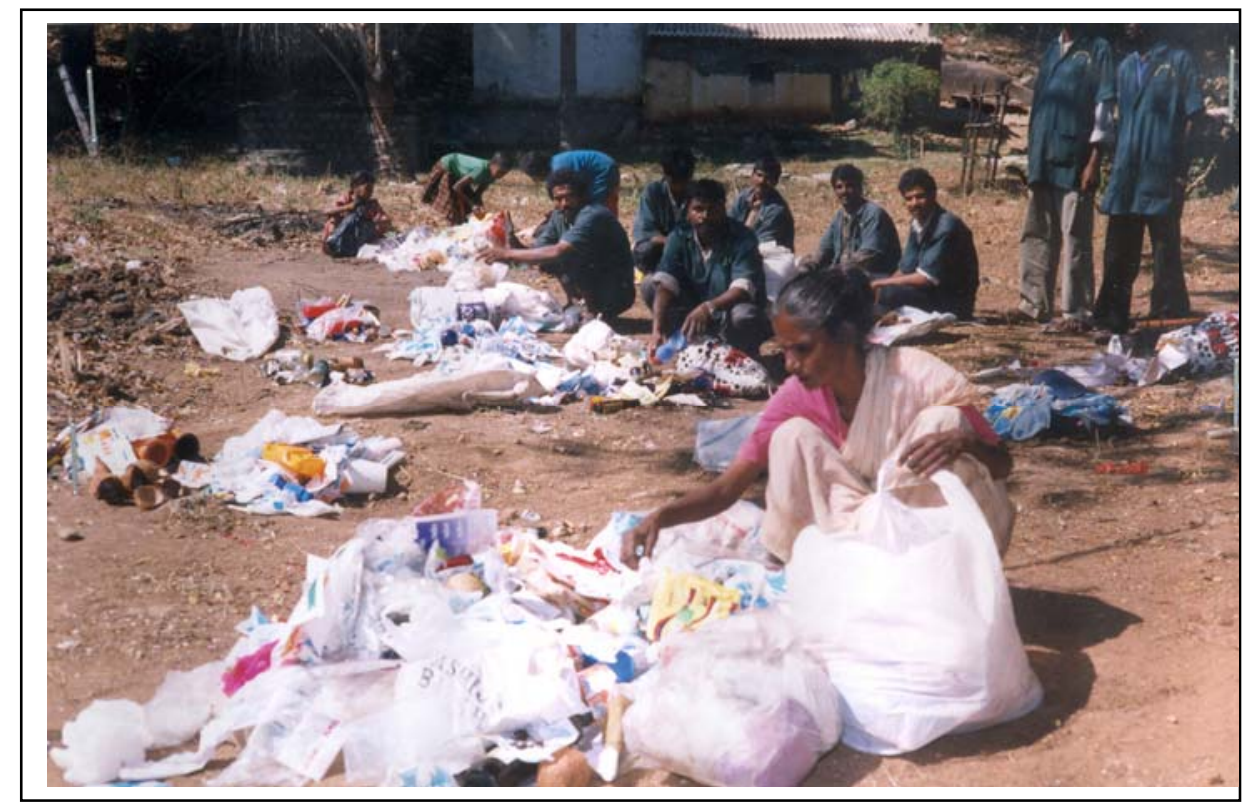

Collection of recyclable material by waste picker from informal sector
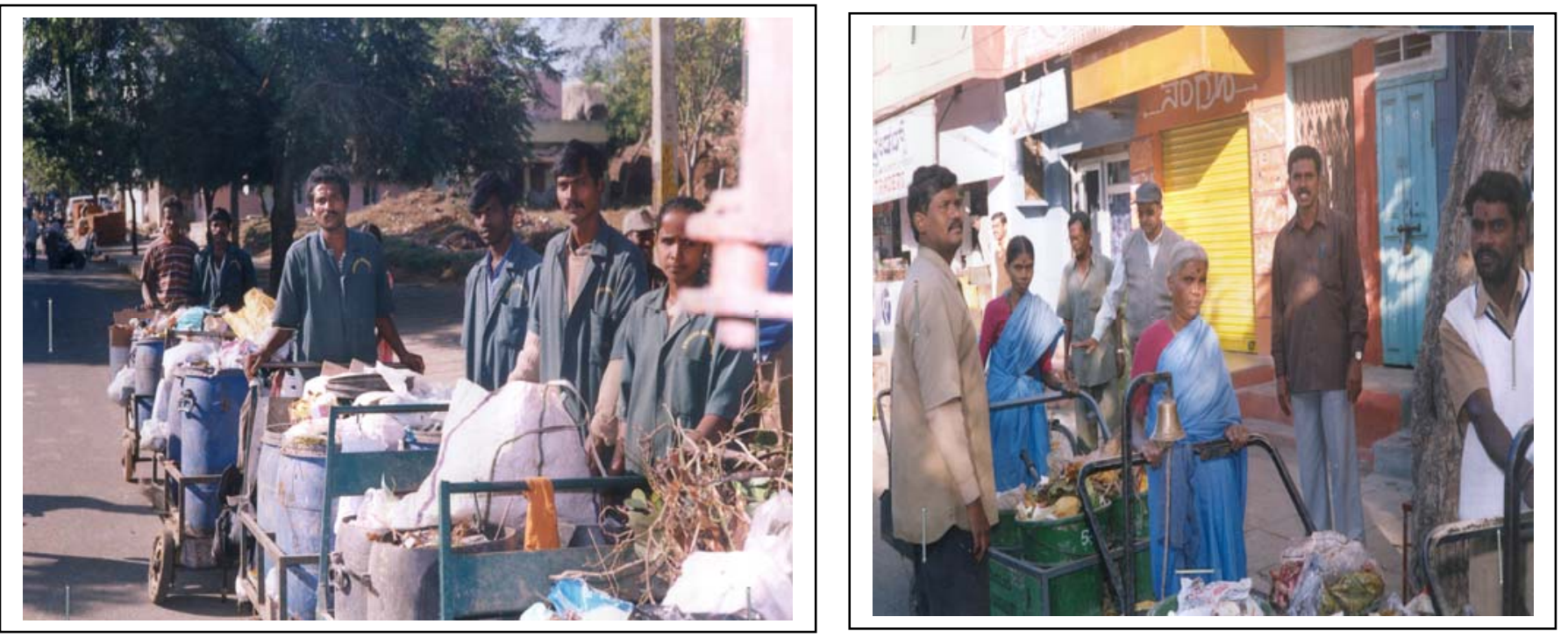

Workers with push cart at synchronization 


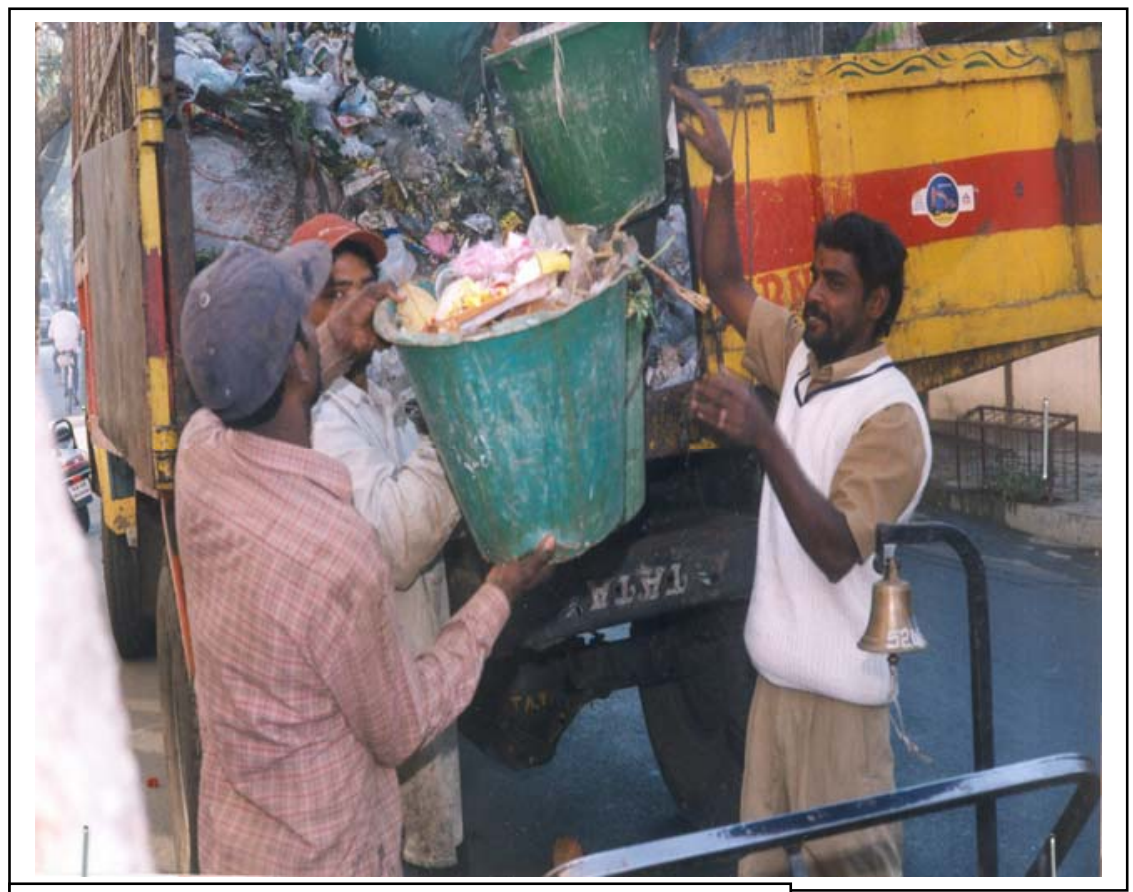

Transfer of waste from nush cart to truck

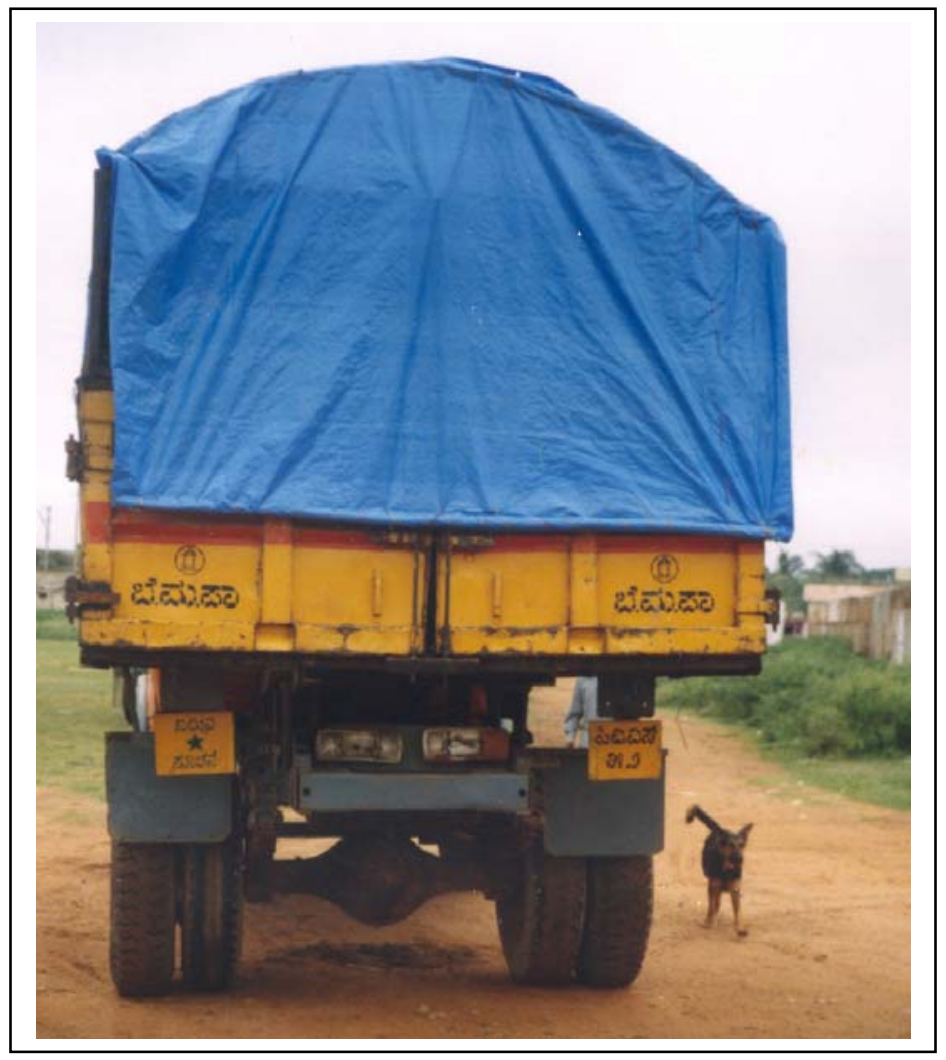

Truck covered with mesh and 


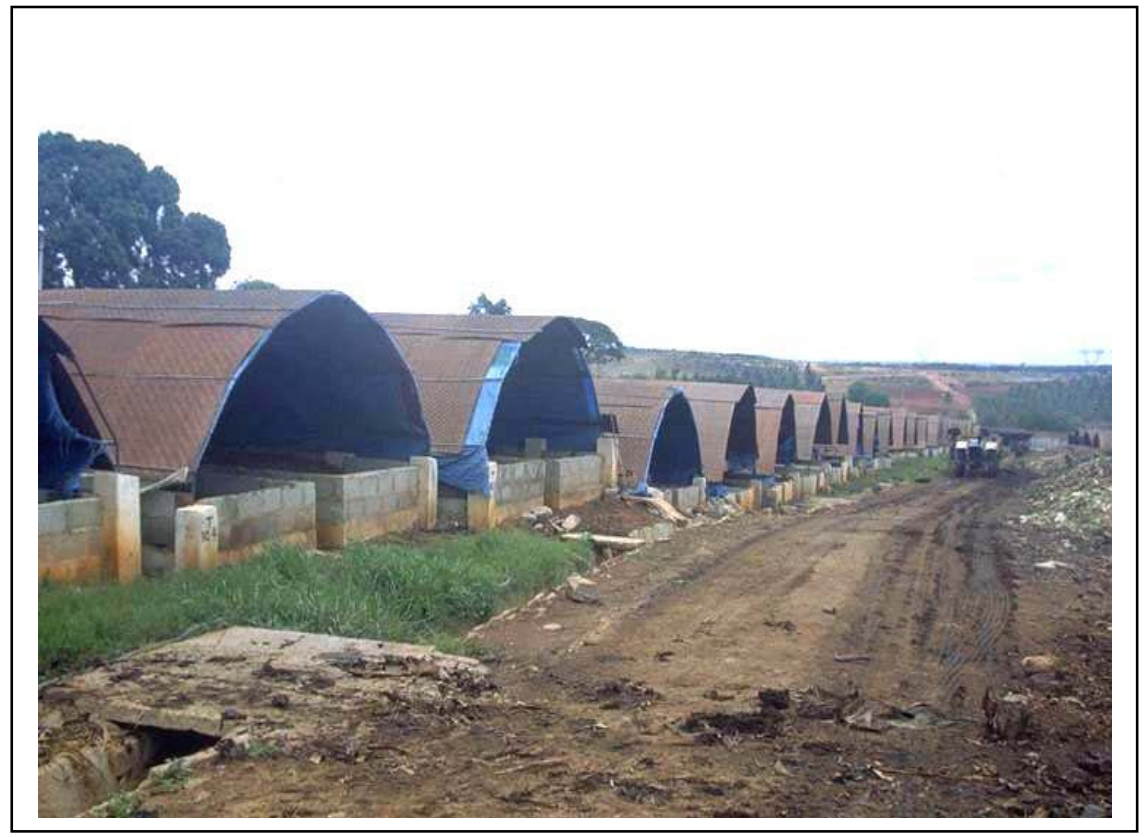

Vermicomposting in Terra Firma Biotechnologies

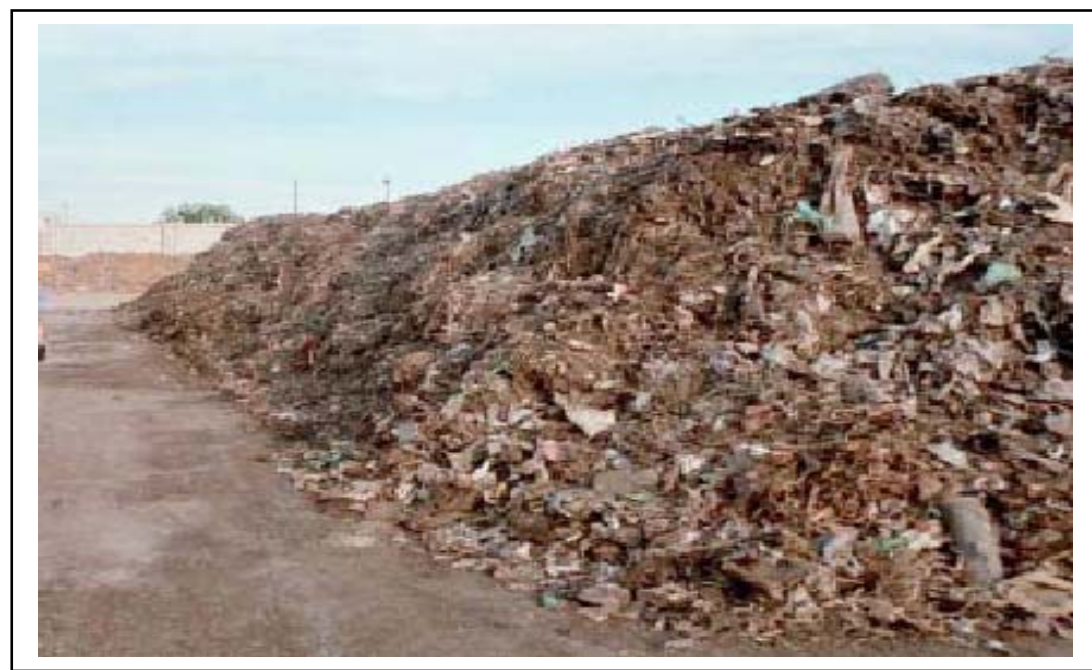

Windrow at KCDC 


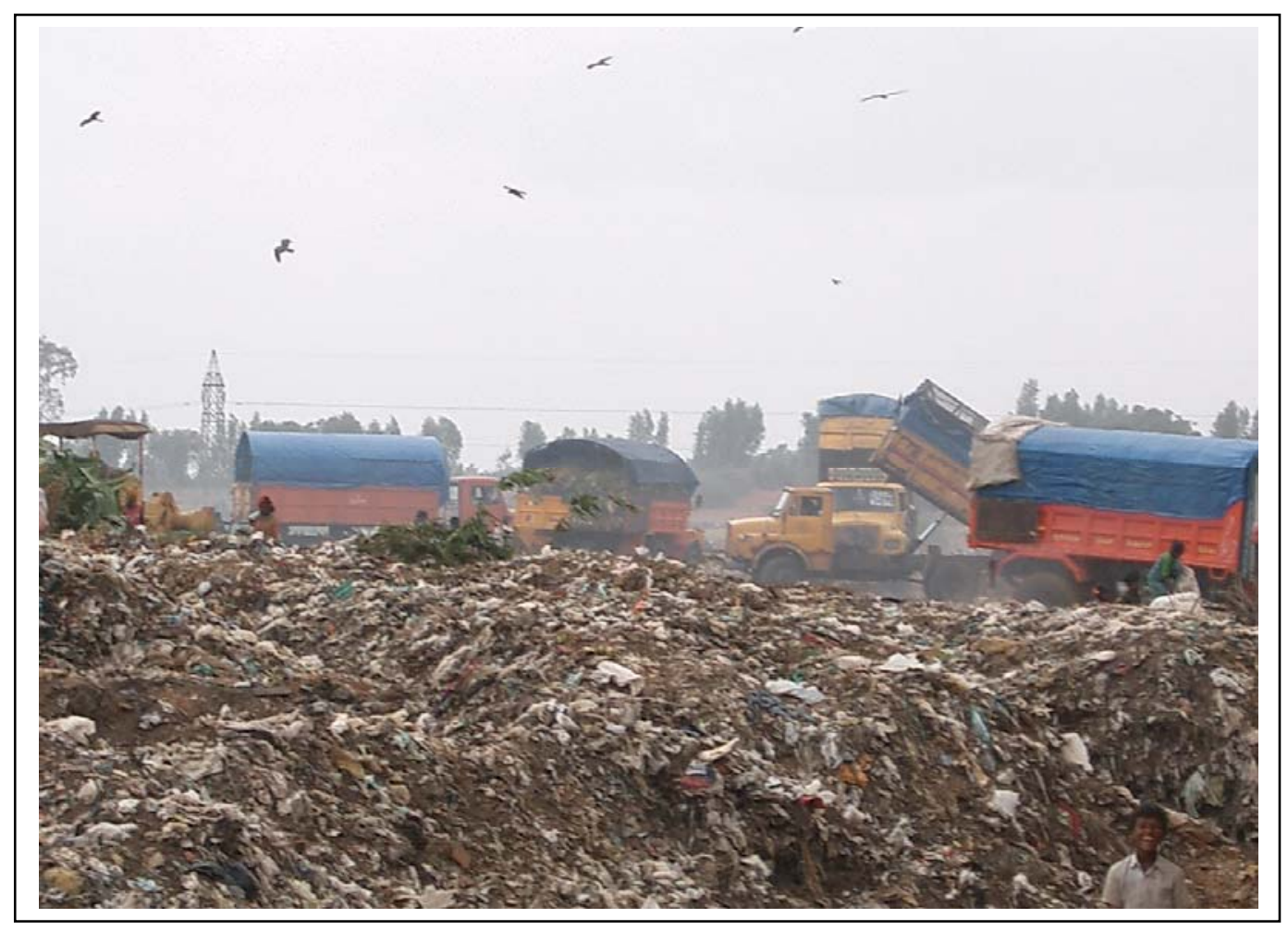

Dump yard in Betahalli

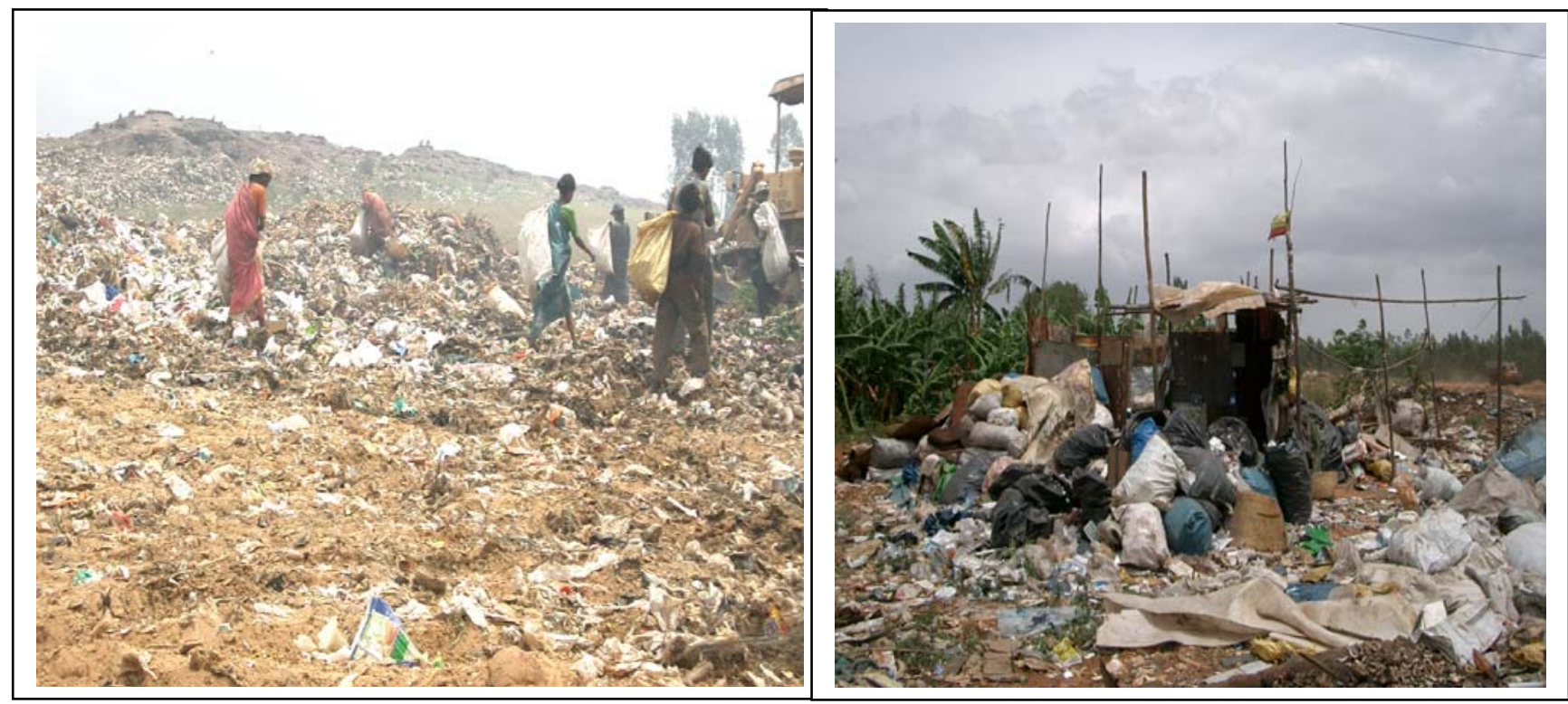

Waste pickers in dump yard

Recyclable waste dealer in dump yard 


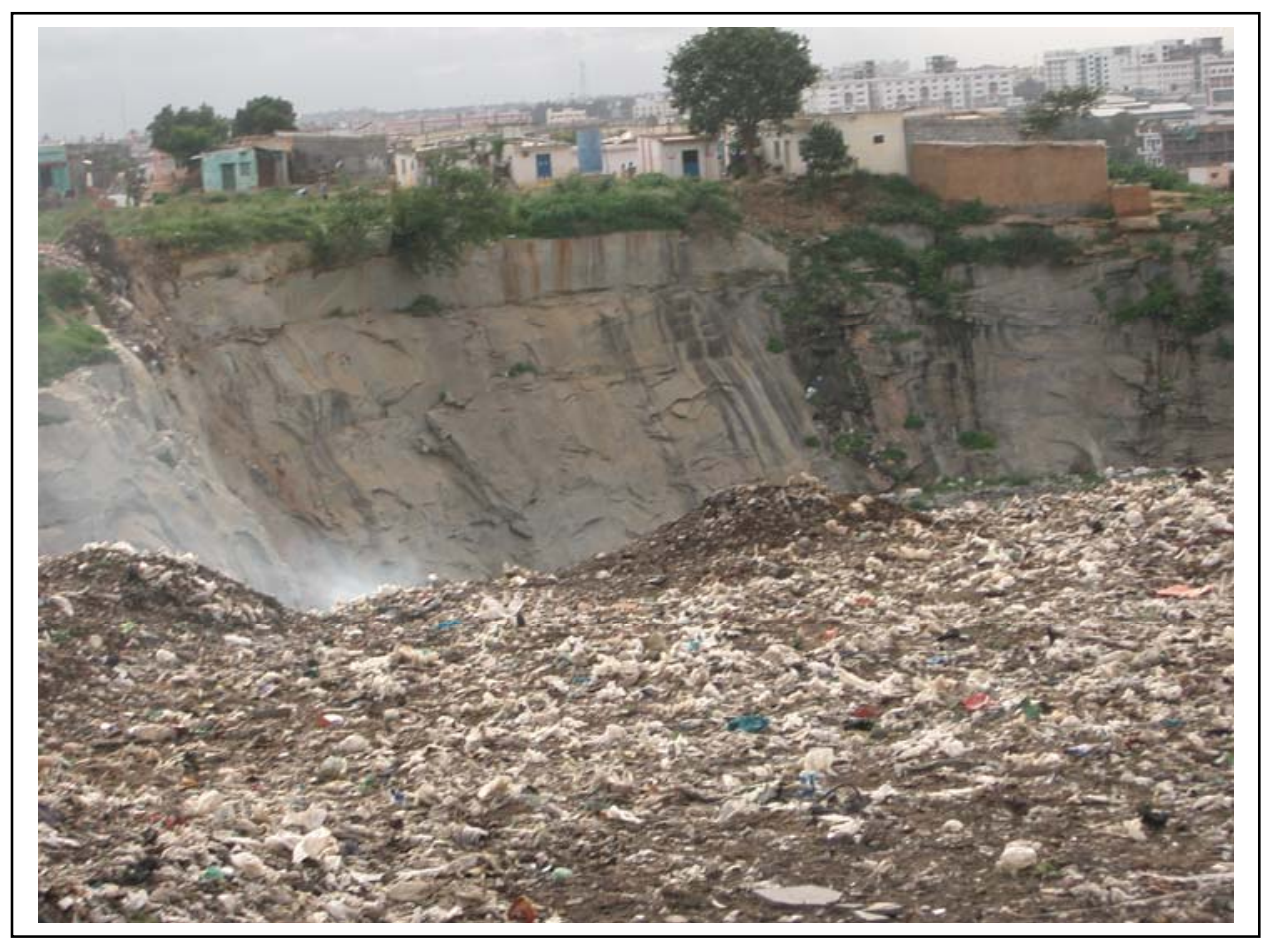

Quarry Site in Bomanhalli, Bangalore 


\section{ANNEXURE 1}

Notification

$22^{\text {nd }}$ April 1993

GSR. 386 (E)- In exercise of the powers conferred by section 6 and 25 of the Environment (Protection) Act, 1986, the central government hereby makes the following rules further to amend the Environment (Protection) Rules, 1986, namely: -

1. a) these rules may be called the Environment Protection Rules, 1993

b) they shall come into force on the date of their publication in the official gazette.

2. In the Environment (Protection) Rules, 1986: -

a) in rule 14

i) For the words 'audit report' whenever they occur, the word 'statement' shall be substituted.

ii) For the figures, letters and words ' $15^{\text {th }}$ day of May' the words $30^{\text {th }}$ day of September shall be substituted.

b) In Appendix " $A$ " for Form V, the following form shall be substituted, namely

"Form V"

- Environmental Statement for the financial year ending the $31^{\text {st }}$ of March. 